\title{
Resumos de dissertações de mestrado e teses de doutorado apresentadas na Faculdade de Medicina de Ribeirão Preto - USP de janeiro a março de 2009
}

\section{Biologia Celular e Molecular}

\section{CARACTERIZAÇÃO FUNCIONAL DA REGIÃO REPRESSORA PROXIMAL DO PROMOTOR DO GENE DE PUFE DE DNA BhC4-1}

\author{
Marcos de Campos Neves \\ Orientadora: Prof ${ }^{\mathrm{a}}$. Dr ${ }^{\mathrm{a}}$. Nadia Monesi \\ Dissertação de Mestrado apresentada em 06/02/2009
}

Os pufes de DNA de Sciaridae são formados nos cromossomos politênicos da glândula salivar durante o último estádio larval e constituem regiões do genoma onde ocorrem amplificação gênica (resultado de eventos de re-iniciação da replicação) e expressão gênica de modo regulado no desenvolvimento. Nosso laboratório utiliza como modelo de estudo o gene BhC4-1 do pufe de DNA C4 do sciarídeo Bradysia hygida, expresso e amplificado na glândula salivar no final do quarto estádio larval, em resposta ao aumento dos níveis de ecdisona que promovem a metamorfose. Dados mais recentes indicam que no final do quarto estádio larval a amplificação e expressão de BhC4-1 são também verificadas em menores níveis na glândula protorácica, órgão larval responsável pela síntese de ecdisteróides.

A caracterização funcional da região promotora de BhC4-1 está sendo realizada no sistema modelo Drosophila melanogaster. Os dados obtidos no sistema heterólogo revelaram que os mecanismos controladores da expressão de BhC4-1 em glândulas salivares de prépupas são conservados em Drosophila. A caracterização funcional da região promotora de BhC4-1 resultou também na identificação de elementos cis-reguladores que regulam a expressão do gene na glândula anelar. A glândula anelar é o principal órgão endócrino larval de Drosophila e é resultado da fusão das glândulas protorácicas, do corpus allatum e do corpus cardiacum. Um elemento cis-regulador identificado constitui o ativador de glândula anelar de 67 pb (-253-187), capaz de promover a expressão do gene BhC4-1 na glândula anelar a partir do final do desenvolvimento embrionário. Além disso, foram identificadas duas regiões repressoras (-1293/-254) e (-3314/-1294), que reprimem o início da expressão do gene na glândula anelar em tempos anteriores ao segundo estádio larval e prépupas 0 hora, respectivamente. O presente trabalho teve como objetivo estender a caracterização funcional da região repressora proximal (-1293/-254). Para tanto, foram obtidas linhagens transformadas com duas construções distintas, (-824/-187) e (488/-187). As construções (-824/-187) e (-488/-187) apresentam a seguinte estrutura: elemento P/ gene de seleção white / (824/-187) ou (-488/-187) do promotor de BhC4-1/ promotor basal de Fbp1/ gene repórter lacZ/ elemento P.

A análise do padrão de expressão da proteína repórter $\beta$-galactosidase nos transformantes revelou que a expressão de BhC4-1-lacZ é inicialmente detectada na glândula anelar de larvas de segundo estádio, continua a ser detectada durante o terceiro estádio larval e o estágio de prépupa e não é mais detectável em pupas 24 horas. Além disso, em embriões e larvas de primeiro estádio foi detectado um padrão de expressão ectópico da proteína repórter, aparentemente localizado na epiderme. Resultados anteriores sugeriam que os repressores da expressão de BhC4-1 na glândula anelar em tempos anteriores ao segundo estádio estão contidos no fragmento (-370/-253). Uma vez que ambas as construções testadas contêm na extremidade 5' o fragmento (-370/-254) e na extremidade 3 ' o ativador de glândula anelar (-253/-187), os resultados obtidos revelam que a presença destes dois módulos cis-reguladores (repressor + ativador), quando testados à montante de um promotor basal heterólogo, é suficiente para regular a expressão de BhC4- 1 na glândula anelar a partir do segundo estádio larval. No conjunto, os dados obtidos contribuem para estender a caracterização da região repressora proximal (-1293/-254) do promotor do gene de pufe de DNA BhC4-1. Mais ainda, uma vez que a caracterização de mecanismos reguladores da transcrição na glândula anelar encontra-se em um estágio inicial, a identificação de elementos repressores que atuam neste tecido deverá, a longo prazo, contribuir também para o entendimento dos mecanismos que regulam a expressão de genes de Drosophila expressos no principal órgão endócrino larval. 


\title{
CLONAGEM MOLECULAR E ANÁLISE DA EXPRESSÃO E IMUNOLOCALIZAÇÃO DE UMA NOVA PROTEÍNA GPI PREDITA DE Paracoccidioides brasiliensis
}

\author{
Clarissa Xavier Resende Valim \\ Orientador: Prof. Dr. Paulo Sérgio Rodrigues Coelho \\ Dissertação de Mestrado apresentada em 13/03/2009
}

Paracoccidioides brasiliensis, um fungo termodimórfico, é o agente etiológico de uma das micoses mais prevalentes da América Latina, a paracoccidioidomicose (PCM). Como em muitos microorganismos patogênicos, as manifestações da doença e seu progresso dependem da interação entre a superfície celular do fungo e componentes do hospedeiro. Genes conhecidos como PGAs (predicted-GPI-anchored) codificam proteínas que apresentam motivos compatíveis com função na superfície celular. Proteínas ancoradas por GPI podem estar envolvidas com funções tais como adesão célula a célula, célula a tecido, além de participar da biogênese e remodelamento da parede de celular. Neste trabalho identificamos uma proteína-GPI predita em sequências protéicas deduzidas de uma biblioteca de EST de P.brasiliensis 18, a qual denominamos PbPga1. Estudos in silico identificaram um sinal de peptídeo para o retículo endoplasmático, um domínio rico em glicina e serina conservado para proteínas GPIs, bem como a presença do sítio ômega e a ausência de domínios transmembrânicos, com predita localização na parede celular. A análise da expressão do gene $P b P G A 1$ por Real Time PCR revelou que esse é expresso diferencialmente entre as formas de hifa e levedura, apresentando-se 3 vezes mais expresso na fase leveduriforme $(\mathrm{P}<0.05)$. A ORF PbPGAl foi clonada em vetor de expressão pGEX3X. Após 5 horas de indução por IPTG, bactérias portando o vetor com a ORF PbPGAl expressaram uma banda de $35 \mathrm{kDa}$ a qual foi detectada na fração insolúvel do lisado celular. Foram produzidos anticorpos policlonais contra a proteína recombinante (GST-PbPga1) em camundongo. Estes foram capazes de reconhecer a GST-PbPga1, bem como uma proteína endógena de $45 \mathrm{KDa}$ em extratos de hifas e leveduras de $P$. brasiliensis. A proteína PbPgal foi imunolocalizada na superfície de células de leveduras, principalmente na base do broto, envolvendo-o na forma de um anel. Em formas de transição de levedura para hifa, observamos a $P b$ Pga1 tanto na base do broto, quanto polarizada na extremidade das hifas em formação. A parede celular de microorganismos constitui um importante reservatório de macromoléculas imunoreativas e um potencial alvo para candidatos a vacinas. Assim, a identificação de uma nova proteína fungo-específica na parede celular de $P$. brasiliensis, a produção de anticorpos específicos, a caracterização de sua expressão e sua imunolocalização celular é de suma importância para a contribuição da evolução no entendimento desse microorganismo.

\section{Bioquímica}

\section{PROTEÍNAS ANCORADAS POR GPI DE PROMASTIGOTAS DE Leishmania amazonensis: ISOLAMENTO E INCORPORAÇÃO EM SISTEMAS MIMÉTICOS DE MEMBRANAS}

\author{
Marcelle Carolina Colhone \\ Orientador: Prof. Dr. Pietro Ciancaglini \\ Tese de Doutorado apresentada em 13/02/2009
}

Neste trabalho, nós investigamos a influência de diferentes lipídios:colesterol (moi: moi) na incorporação de proteínas ancoradas por glicosilfosfatidilinositol (GPI) de Leishmania amazonensis em lipossomos e monocamadas de Langmuir. Em um segundo passo, nós avaliamos se proteolipossomos carregando proteínas ancoradas por GPI de formas promastigotas do parasita podem induzir imunidade protetora em camundongos BALB/c. Lipossomos foram formados em todas as condições estudadas, mas a incorporação das proteínas ancoradas por GPI ocorreu somente na presença do colesterol, alcançando um máximo de adsorção da proteína (57 $\pm 9 \%$ ) quando a razão molar 2,1:1 de dipalmitoilfosfatidilcolina (DPPC): Colesterol foi usada. $\mathrm{O}$ aumento da quantidade de colesterol não aumenta a adsorção das proteínas ancoradas por GPI. Além disso, na ausência do colesterol, a reconstituição é mais dificultada, sendo este resultado confirmado por experimentos em monocamadas de Langmuir, onde a inserção da proteína via GPI, leva a desestabilização da monocamada de DPPC. Para avaliar a proteção, camundongos BALB/c foram injetados intraperitonealmente com tampão, lipossomos, extrato bruto de proteínas ancoradas por GPI solubilizadas com Triton X-114 $\left(\right.$ EBS $\left._{\mathrm{GPI}}\right)$ ou proteolipossomos e, após três semanas, foram desafiados na pata traseira direita com $10^{4}$ formas promastigotas de L. amazonensis. A proteção foi avaliada semanalmente até a $14^{\mathrm{a}}$ semana através de medidas do tamanho das lesões causadas pelo parasita. Camundongos 
BALB/c imunizados com $40 \mu \mathrm{g}$ (proteínas totais) de proteolipossomos mostraram uma proteção de $50 \%$, quando comparados aos camundongos que receberam somente tampão. Entretanto, camundongos imunizados com $5 \mu \mathrm{g}$ (proteínas totais) de $\mathrm{EBS}_{\mathrm{GPI}}$ mostraram um máximo de proteção de 60 \% pós infecção. Assim, esses resultados indicam que tanto o EBS $_{\text {GPI }}$ quanto os proteolipossomos podem ser usados para induzir imunidade protetora em camundongos contra $L$. amazonensis. Além disso, macrófagos peritoneais murinos estimulados com lipossomos, $\mathrm{EBS}_{\mathrm{GPI}}$ ou proteolipossomos mostraram redução da porcentagem de células infectadas (42,39 e 99\%, respectivamente) e do número de parasitas intracelulares por célula $(29,32$ e $99 \%$, respectivamente). A cinética de infecção indica que diferentes estímulos não impediram a fagocitose de amastigotas de L. amazonensis, mas induziram macrófagos a reduzirem o parasitismo intracelular.

\title{
PRODUÇÃO, PROPRIEDADES BIOQUÍMICAS E FUNCIONAIS DO SISTEMA XILANOLÍTICO DE Aspergilli E APLICAÇÃO BIOTECNOLÓGICA NO BRANQUEAMENTO DA POLPA DE CELULOSE E EM RAÇÃO ANIMAL
}

\author{
Simone de Carvalho Peixoto-Nogueira \\ Orientadora: $\operatorname{Prof}^{\mathrm{a}}$. Dra ${ }^{\mathrm{a}}$. Maria de Lourdes Teixeira de Moraes Polizeli \\ Tese de Doutorado apresentada em 20/02/2009
}

Por meio de um programa de bioprospecção foram selecionados dois bons produtores de xilanases: Aspergillus fumigatus e Aspergillus niveus, os quais foram cultivados em meio líquido mínimo de Vogel ou (zapeck, suplementados com xilana birchwood $1 \%$ para A. fumigatus e A. niveus, respectivamente, a $40^{\circ} \mathrm{C}$, condições estáticas, durante 96 ou 120 horas, respectivamente. A produção xilanásica também foi elevada em resíduos agroindustriais como flocos de arroz, farejo de trigo, sabugo de milho, milho moído e palha de arroz - A. fumigatus; farejo de trigo e milho moído - A. niveus. Os ótimos de temperatura corresponderam a $70^{\circ} \mathrm{C}$ ou $60-65^{\circ} \mathrm{C}$ para A. fumigatus e $A$. niveus, respectivamente, enquanto que os ótimos de pH de reação corresponderam a 5,0-5,5 e 4,5-5,0. A termoestabilidade das enzimas brutas foram similares a 600(durante 30 minutos. Após este período a atividade residual da xilanase de A. fumigatus reduziu consideravelmente e, após 120 minutos, restou apenas $10 \%$ de sua atividade inicial, enquanto que a xilanase de A. niveus ainda manteve $30 \%$ de sua atividade. Frente a diferentes pHs as xilanases de ambos os fungos mantiveram 100\% da atividade inicial em pHs 6,0-8,0 (A. fumigatus) ou em 4,5-6,0 (A. niveus). Para as ligninases (Iacase, Mn-P e Li-P) as condições de cultivo padronizadas foram FSS com farejo de trigo como fonte de carbono durante 14, 21 e 35 dias, respectivamente. A adição de fonte de nitrogênio inorgânica favoreceu a síntese dessas enzimas e as temperaturas de reação corresponderam a $60^{\circ} \mathrm{C}$-lacase e Mn-P ou $70^{\circ} \mathrm{C}$ -Li-P; a faixa de $\mathrm{pH}$ de maior atividade variou de 4,0-7,0. Mn-P e Li- P não perderam nem mesmo $50 \%$ de sua atividade após uma hora em temperaturas de $25-80^{\circ} \mathrm{C}$, já a lacase perdeu $50 \%$ em temperaturas de $75-80^{\circ} \mathrm{CNo}$ biobranqueamento da polpa de celulose os resultados foram promissores: xilanase de A. niveus diminuiu 4,6 pontos do número kappa, aumentou 3,4 pontos na alvura e manteve a viscosidade; xilanase de A. fumigatus reduziu 0,9 pontos do kappa, aumentou 2 pontos na alvura e reduziu $9,2 \%$ na viscosidade. Para o mix de xilanasesfligninases de A. niveus houve redução de 6,5 pontos do kappa, aumento de 17,2 pontos na alvura e a viscosidade reduziu 1 ponto. Por meio de microscopia eletrônica de varredura confirmou-se a eficiência desses tratamentos. Nos testes in vitro realizados no setor de rações houve um aumento de 6,0$10,8 \%$ na digestibilidade in vitro e, nos testes in vivo, as xilanases de A. niveus mantiveram-se estáveis por até 8 horas dentro do rúmen de caprinos. Houve também uma maior liberação de gases na presença das enzimas produzidas por $A$. niveus, um outro indicativo de maior digestibilidade. Os extratos brutos de A. niveus e A. fumigatus não apresentaram nenhum caráter citotóxico. Para purificar duas das isoformas de xilanase produzidas por A. niveus utilizou-se tratamento com caulin e colunas cromatográficas de troca iônica e de exclusão de massa molecular; A. niveus produziu, pelo menos, seis isoformas xilanolíticas, das quais duas foram purificadas. Seus respectivos fatores de purificação foram 4407,0 e 612,1 vezes para as xilanases denominadas de CMC 2 e biogel 2, respectivamente. Já as massas moleculares corresponderam a 52,5 e 21,8 kDa em SDS-PAGE; por FPLC foram 19,5 kDa para ambas as isoformas purificadas. Verificou-se que compostos como trealose, sorbitol e glicerol protegeram as xilanases puras e aumentaram sua termoestabilidade. As xilanases CMC 2 e biogel 2 apresentaram, respectivamente, $33,8 \%$ e $11,56 \%$ de carboidratos na molécula. A isoforma CMC 2 teve sua atividade aumentada na presença de alguns compostos como $\mathrm{MnCI}_{4 \mathrm{HO}}, \beta$-mercaptoetanol e cisteína e, análises em TLC confirmaram que ambas as isoformas tratavam-se de endoxilanases. Estudos de dicroísmo circular confirmaram se tratar de duas xilanases, uma vez que os perfis dessas análises indicaram proteínas ricas em cadeias ß-folha como deve ser uma xilanase. Já as análises de sequenciamento de aminoácidos mostraram uma grande identidade entre a sequência das xilanases de A. niveus e xilanases de outros microrganismos. 


\title{
ESTUDO DO COMPLEXO CELULOLÍTICO DO FUNGO TERMÓFILO Scytalidium thermophilum: PRO- DUÇÃO, CARACTERIZAÇÃO BIOQUÍMICA E PURIFICAÇÃO DE UMA ENDOGLUCANASE
}

\author{
Jean Carlos Rodrigues da Silva \\ Orientador: Prof. Dr. João Atílio Jorge \\ Dissertação de Mestrado apresentada em 02/03/2009
}

A celulose é o mais abundante recurso natural biológico renovável e sua hidrólise é catalisada por celulases. Estas enzimas são classificadas como endoglucanases, exoglucanases e $\beta$-glucosidases, e agem de forma diferente, hidrolisando ligações glicosídicas do tipo $\beta 1 \rightarrow 4$. Endoglucanases hidrolisam aleatoriamente ligações glicosídicas acessíveis das cadeias de celulose produzindo novas cadeias terminais; as exoglucanases clivam progressivamente cadeias de celulose a partir de suas extremidades, liberando celobiose solúvel; e as $\beta$-glucosidases hidrolisam celobiose à glicose. Celulases são produzidas por um grande número fungos e de bactérias. Estas enzimas são aplicadas em indústrias de detergente, amido, suco de fruta, papel, alimento e cerveja. Celulases podem ser usadas diretamente na preparação dos produtos comerciais ou posteriormente, no tratamento dos resíduos. Nos últimos cinco anos, há um interesse crescente na produção de etanol a partir da biomassa lignocelulósica. O objetivo deste trabalho foi estudar a produção e as propriedades bioquímicas das celulases do fungo termófilo Scytalidium thermophilum. A maior produção de atividade da celulase ocorreu após de $72 \mathrm{~h}$ de crescimento, em meio de cultura contendo substratos celulósicos. As condições ótimas aparentes para atividades da celulase foram determinadas no filtrado bruto. As condições ótimas de $\mathrm{pH}$ e temperatura foram $4,0,6,0,5,0$ e $55^{\circ} \mathrm{C}, 60^{\circ} \mathrm{C} \mathrm{e}$ $55^{\circ} \mathrm{C}$, para atividades de CMCase, avicelase e FPase, respectivamente. Interessantemente, as celulases de Scytalidium no filtrado bruto não exibiram significativa inibição na presença de glicose e celobiose no meio reacional. Na tentativa de purificação das celulases, foi utilizado um procedimento envolvendo a precipitação por sulfato do amônio e cromatografia em CM-Fractogel. Uma endoglucanase (CMcase) foi purificada por este procedimento, como indicado por análises de PAGE e SDS-PAGE. A enzima foi purificada 13,76 vezes, a preparação final exibiu uma atividade específica de 76,38 U/mg de proteína e um rendimento de $16 \%$. As massas moleculares aparentes determinadas por SDS-PAGE e por filtração em gel foram $47 \mathrm{kDa}$ e $44 \mathrm{kDa}$, respectivamente. As condições ótimas aparentes de $\mathrm{pH}$ e temperatura foram 4,5 e $60^{\circ} \mathrm{C}$, respectivamente. A enzima purificada hidrolisou eficientemente CMC e exibiu a pouca especificidade para avicel, papel de filtro, o amido e celobiose. Os íons mercúrio, cobre e alumínio inibiram a CMCase purificada, enquanto que o $\beta$-mercaptoetanol e o cobalto estimularam a enzima. As meias-vidas da enzima quando incubada a $60^{\circ} \mathrm{C} \mathrm{em} \mathrm{meio} \mathrm{aquoso} \mathrm{ou} \mathrm{a} 70^{\circ} \mathrm{C}$ em meio contendo $1 \%$ de $\mathrm{CMC}$ foram de 23 minutos e 46 minutos, respectivamente. A enzima exibiu $\mathrm{K}_{\mathrm{m}} \mathrm{e} \mathrm{V}_{\text {máx }}$ para o CMC de $0,8 \%$ (p/v) e 122,5 U/mg de proteína, respectivamente. Os resultados encontrados sugerem que a endoglucanase de Scytalidium estudada tem potencial para aplicações biotecnológicas em processos de sacarificação.

\section{ESTUDO DA PARTICIPAÇÃO DOS SISTEMAS RENINA-ANGIOTENSINA E CALICREÍNAS-CININAS EM PROCESSOS INFLAMATÓRIOS DA CAVIDADE ORAL}

\author{
Pedro Paulo Chaves de Souza \\ Orientador: Prof. Dr. Claudio Miguel da Costa Neto \\ Tese de Doutorado apresentada em 24/03/2009
}

O dente e seus tecidos de suporte estão locallizados na cavidade oral, expostos ao microambiente oral, que contém cerca de 500 espécies de bactérias já identificadas. A proliferação destes microrganismos na superfície do dente pode levar ao desenvolvimento de algumas Patologias, como a pulpite e a periodontite. Assim como em outras desordens inflamatórias, o balanço entre os patógenos e a defesa do hospedeiro determina a severidade da doença. O sistema calicreínacininas (SCC) e o sistema renina-angiotensina (SRA), classicamente relacionados ao controle do tõnus vascular e ao balanço hidroeletrolítico, vêm sendo relacionados nos últimos tempos a alguns tipos de processos inflamatórios. $\mathrm{O}$ objetivo deste estudo foi avaliar a participação destes sistemas na pulpite a na periodontite. Para este fim, foram utlizados dois modelos, um de exposição pulpar de dente de rato e outro de cultura primária de fibroblastos de gengiva humana. No modelo de pulpite induzida em ratos, demonstramos que o receptor $\mathrm{AT}_{1}$ é constitutivamente expresso na polpa dental, e o nível de expressão do seu RNAm é diminuído 24h após a exposição pulpar. Já o receptor AT 2 é expresso em baixos níveis, e a expressão do seu RNAm é aumentada após exposição pulpar. $\mathrm{O}$ receptor $\mathrm{B}_{2}$ é constitutivamente expresso na polpa dental, e a indução da pulpite não leva a alteração dos seus níveis. Já o receptor $\mathrm{B}_{1}$ tem sua expressão aumentada na pulpite. Além disso, o bloqueio do receptor $\mathrm{B}_{2}$ suprime o aumento na expressão de COX2 induzido pelo processo inflamatório na polpa dental. Fibroblastos de polpa dental humana foram isolados a fim de confirmar a participação das cininas na modulação da expressão de COX2. Neste modelo, a bradicinina estimulou um aumento na expressão do RNAm de COX2 nestas células. Para o estudo da ação do LPS de $P$. gingivalis em células do periodonto, foram utilizados firoblastos de 
gengiva humana. No modelo de cultura primária de fibroblastos de gengiva, demonstramos que o LPS de $P$. gingivalis, agindo via TLR2, é capaz de hiper-regular a expressão dos receptores $\mathrm{B}_{1}$ e $\mathrm{B}_{2}$, em um mecanismo dependente da liberação de TNF- $\alpha$. No mesmo modelo, demosntramos também que algumas citocinas que atuam no metabolismo ósseo, também são reguladas. O LPS de $P$. gingivalis foi capaz de aumentar a expressão de IL-6, LIF e MCSF, mas não de IL-11, OSM, OPG e RANKL. Podemos concluir que os componentes do SCC e do SRA são modulados na pulpite e participam desta patologia. Concluímos também que o LPS de $P$. gingivalis é capaz de aumentar a expressão do RNAm de citocinas osteotrópicas e de receptores de cininas, ativando TLR2.

\title{
CLONAGEM, EXPRESSÃO E CARACTERIZAÇÃO MOLECULAR E FUNCIONAL DA SUBUNIDADE Rpn10 DO PROTEASSOMA DE Schistosoma mansoni
}

\section{Enyara Rezende Morais}

Orientador: Prof. Dr. Vanderlei Rodrigues

Dissertação de Mestrado apresentada em 30/03/2009

A degradação intracelular de proteínas mediada pelo sistema de ubiquitina e proteassoma é uma importante rota na qual inúmeras proteínas são marcadas para a destruição. É importante entender como o proteassoma $26 \mathrm{~S}$ reconhece especificamente proteínas poliubiquitinadas, porque este reconhecimento é o processo chave na degradação seletiva destas proteínas. Estudos mostraram que uma subunidade de 50KDa do complexo 19S humano, originalmente chamada de S5a ou Rpnl0, poderia ligar conjugados poliubiquitinados in vitro. No presente estudo, foi feita a caracterização molecular e funcional da subunidade Rpn10 do proteassoma do parasita Schistosoma mansoni durante seu ciclo evolutivo e também, a avaliação desta como alvo de vacina contra a esquistossomose. Assim, o gene que codifica para Rpnl0 foi recuperado dos bancos de dados do parasita, clonado, expresso em sistema heterólogo, e a proteína recombinante foi purificada. A partir da proteína purificada, camundongos foram imunizados para a produção de anticorpos específicos anti-Rpnl0. Nossos resultados demonstraram que a expressão do gene que codifica para SmRpnl0 é diferencialmente expresso. Em relação à proteína, observamos a presença de SmRpnl0 na fase de ovos. A imunização com a SmRpnl0 induziu 20\% de proteção contra a infecção experimental com S. mansoni. O experimento de purificação de conjugados poliubiquitinados por afinidade a Rpnl0 indicou que a proteína é funcional. Considerando o papel da Rpnl0 como receptora de substratos poliubiquitinados nossos resultados indicam que a proteína é funcional e faz-se importante conhecer os conjugados poliubiquitinados por ela reconhecidos e o impacto geral dela no turnover de substratos do proteassoma de S. mansoni.

\section{Clínica Cirúrgica}

\section{EFEITOS DA ELETROESTIMULAÇÃO INTRAVAGINAL NA FUNÇÃO VESICAL E NA ATIVIDADE NEURONAL DO CENTRO PONTINO DA MICÇÃO EM RATAS ÇOM CISTITE HEMORRÁGICA}

\author{
Carla Adelino Suaid \\ Orientador: Prof.Dr. Silvio Tucci Junior \\ Tese de Doutorado apresentada em 12/01/2009
}

No presente estudo analisou-se os efeitos da eletroestimução intravaginal (EI) de baixa frequência na função vesical e na expressão de c-FOS e da síntase do óxido nítrico (nNOS) em neurônios do centro pontino da micção em ratas com cistite hemorrágica induzida pela ciclofosfamida (CF). Trinta ratas Wistar foram divididas em 5 grupos iguais: G1controle normal; G2 - EI simulada na cistite aguda (CF na dose 200mg/Kg); G3 - EI na cistite aguda (CF na dose 200mg/Kg); G4 - EI simulada na cistite crônica (3 injeções de CF na dose de $75 \mathrm{mg} / \mathrm{Kg}$ a cada 4 dias); G5 - EI na cistite crônica (3 injeções de CF na dose de $75 \mathrm{mg} / \mathrm{Kg}$ a cada 4 dias). O estudo urodinâmico foi realizado 16 horas após a injeção de CF e, antes e 2 horas após da EI. Os parâmetros analisados foram: frequência miccional (FM), tempo de enchimento vesical (TE) e de contração (TC), capacidade vesical (CV) e pressão vesical máxima (PVM). A expressão do c-FOS e nNOS nos neurônios do centro pontino da micção (CPM) foi determinada pelo método de imunofluorescência. Observou-se a presença de processo inflamatório agudo hemorrágico nos grupos com indução aguda da cistite e, inflamatório crônico inespecífico nos grupos com indução crônica pela coloração de hematoxilina-eosina. $\mathrm{O}$ aumento do peso úmido da bexiga foi significantemente maior nos grupos crônicos $(0,27 \pm 0,01 \mathrm{~g})$ do que nos agudos $(0,2 \pm 0,01 \mathrm{~g})$. Os grupos submetidos à EI mostraram diferenças significativas em todos os parâmetros urodinâmicos estudados, com exceção da PVM, na comparação intra e entre os grupos. Após 2 horas da EI, houve diminuição significativa da FM, e, concomitantemente, aumento do TE, TC e 
da CV nos animais com cistite-induzida aguda e crônica. Esses parâmetros apresentaram valores médios semelhantes aos das ratas normais e diferentes significativamente dos animais submetidos à EI simulada. Evidenciou-se diferença significativa do número de neurônios imunorreativos para proteína FOS e nNOS entre os grupos simulados e tratados com EI no CPM. Nos grupos estimulados houve diminuição significativa da expressão de c-FOS e aumento da nNOS quando comparados com os simulados. Ambas as expressões neuronais, c-FOS e nNOS, nos grupos tratados com EI apresentaram valores médios semelhantes ao do grupo controle - G1. A maioria dos neurônios nitrinérgicos presentes no CPM não expressaram c-FOS nuclear, ou seja, não houve coexpressão da atividade neuronal. A EI promoveu a modulação da atividade neuronal do CPM e, consequentemente, normalizou a função vesical das ratas com hiperatividade detrusora.

\title{
AVALIAČ̃̃O DO MANEJO DE CÓLON NAS CRIANÇAS COM CONSTIPAÇÃO INTESTINAL CRÔNICA DE DIFÍCIL TRATAMEMENTO
}

\section{Alexandra Longo Camperoni}

Orientadora: Prof ${ }^{\mathrm{a}}$. Dr ${ }^{\mathrm{a}}$. Yvone Avalloni Moraes Villela de Andrade Vicente

Dissertação de Mestrado apresentada em 09/03/2009

A constipação crônica, problema comum na infância, corresponde a cerca de 20 a $25 \%$ das consultas em Serviços de Gastroenterologia Pediátrica. Embora muitos casos possam ser bem controlados, com medidas dietéticas e laxativas usuais, uma grande parcela dos pacientes encaminhados ao cirurgião pediátrico apresenta constipação grave, sem resposta aos tratamentos usuais e, frequentemente associados ao escape fecal e distúrbios psicológicos secundários, causando grande transtorno familiar. O manejo de cólon é uma opção terapêutica para os pacientes com constipação intestinal crônica de difícil tratamento, sendo proposto inicialmente por Peña (1996), com resultados muito positivos, o que levou o Serviço de Cirurgia Pediátrica do Hospital das Clínicas de Ribeirão Preto a criar o seu Ambulatório Interdisciplinar de Manejo de Cólon, foco desse estudo retrospectivo, que analisou os pacientes antes e após o programa de manejo, com vistas a comprovar alguns aspectos da fisiopatologia da constipação crônica funcional na infância e avaliar a eficácia do tratamento. O estudo incluiu 40 crianças com constipação intestinal crônica funcional; 33 pacientes do sexo masculino, 7 pacientes do sexo feminino, com idade de 2 meses e 16 dias a 15 anos e três meses. Todos os pacientes já haviam sido submetidos à tratamento prévio. Os pacientes foram divididos em dois grupos: pré-manejo e pós- manejo, avaliando-se os seguintes dados: escape fecal, vontade de evacuar, evacuação espontânea, alteração da coluna lombossacra, Índice de Peña. Estes dados foram correlacionados com a presença ou ausência de megacólon ao enema opaco. Pudemos observar que o escape fecal estava presente em 24 pacientes (72\%), destes, $73 \%$ apresentavam megarreto. 22 pacientes não apresentavam vontade de evacuar antes do manejo e também uma proporção aumentada de megarreto $(78 \%)$. Entre aqueles que não apresentavam evacuação espontânea antes do manejo (80\%), a maior parte tinha megassigmóide no enema opaco (61\%). Após períodos variáveis de manejo de cólon (1 mês a 3 anos), o que se constatou foi melhora em todos os parâmetros clínicos estudados e melhora radiológica, com normalização do enema opaco em $80 \%$ dos casos. Entre os casos de falha terapêutica estão aqueles com baixa adesão e em fase ainda inicial do tratamento, exceto um único paciente com diagnóstico de Doença de Hirschsprung, firmado após a instituição do programa de manejo de cólon. Concluímos que há associação dos aspectos clínicos: constipação, escape fecal e perda da evacuação espontânea com a dilatação do reto e / ou sigmóide e que o programa de manejo de cólon para o tratamento da constipação crônica funcional na infância é eficiente.

\section{REPERCUSSÃO HEMODINÂMICA E VIABILIDADE DA MONOBRA DE RECRUTAMENTO ALVEOLAR, NO PÓS-OPERATÓRIO IMEDIATO DA CORREÇÃO DE CARDIOPATIAS CONGÊNITAS COM HIPERFLUXO E HIPERTENSÃO PULMONARES}

\author{
Érica de Freitas Amorim \\ Orientador: Prof.Dr. Walter Villela de Andrade Vicente \\ Dissertação de Mestrado apresentada em 10/03/2009
}

A etiologia da redução da função pulmonar após a correção das cardiopatias congênitas com Hipertensão Pulmonar (HP) envolve a combinação de diversos fatores, como anestesia geral, esternotomia mediana, CEC, dor e persistência da RVP no pós-operatório imediato, acrescidos de atelectasia, e hipoxemia. A manobra de recrutamento alveolar (MRA) é uma estratégia de re-expansão dos alvéolos colapsados de modo a normalizar a CRF e melhorar oxigenação alveolar. É muito utilizada na população adulta, mas pouco estudada em crianças no pós-operatório cardíaco. Objetivo: Verificar as repercussões hemodinâmicas e a viabilidade clínica da utilização de um protocolo de MRA no pós-operatório imeiato de correção de cardiopatias congênitas com hiperfluxo pulmonar associada à HP com PAPM $\geq 25 \mathrm{cmH} 2 \mathrm{O}$ respectivamente, Foram avaliadas as medidas da FC, PAM, PAPM, PAE, PVC, bem como SpO2, ETCO2, PaO2/FiO2 e PaO2 e PaCO2, SvO2. 


\title{
ANÁLISE RETROSPECTIVA DA ASSOCIAÇÃO DE RADIOTERAPIA CONFORMADA PÓS-OPERATÓRIA E RADIOCIRURGIA EM PACIENTES PORTADORES DE GLIOBLASTOMA - RESULTADOS DE UMA INSTITUIÇÃO
}

\author{
Felipe Amstalden Trevisan \\ Orientador: Prof.Dr. Carlos Gilberto Carlotti Junior \\ Dissertação de Mestrado apresentada em 20/03/2009
}

Objetivos: No tratamento do glioblastoma, a radioterapia é a modalidade adjuvante que mais se destaca, no entanto, existem dúvidas a respeito da eficácia do aumento de dose de radiação liberada ao volume-alvo, acima de 60Gy, através de técnicas especiais, como a radiocirurgia. Os ojetivos deste estudo foram comapar os dados de sobrevida e de efeitos colaterais induzidos pela radioterapia, de pacientes portadores de glioblastoma, tatados com radioterapia conformada pós-operatória seguida de radiocirurgia. Casuística e métodos: Foram avaliados retrospectivamente os resultados do tratamento de 58 pacientes, divididos em dois grupos, com diagnóstico de Oncologia de Campinas, no período compreendido entre maio de 1997 e janeiro de 2005. Os dois grupos foram tratados com radioterapia conformada cerebral e um deles recebeu tratamento complementar com radiocirurgia. Resultados: A sobrevida mediana dos pacientes submetidos e dos não submetidos a raciocirurgia foi de 73 semanas e 59,3 semanas, respectivamente $(\mathrm{p}=0,657)$. Quanto aos efeitos colaterais, não houve diferença estatisticamente significativa entre os pacientes submetidos e os não submetidos a radiocirurgia. Conclusões: A associação de radiocirurgia à radioterapia pós-operatória não trouxe benefícios aos pacientes portadores de glioblastoma. Os efeitos colaterais apresentados pelo grupo tratado com radiocirurgia foram estatisticamente equivalentes aos do grupo submetido apenas a radioterapia conformada pós-operatória.

\section{Clínica Médica}

\section{AVALIAÇÃO DOS IMPACTOS DA INFORMATIZAÇÃO INTRA-HOSPITALAR SOBRE A GESTÃO DE CUSTOS EXEMPLO: PRESCRIÇÃO DAS FÓRMULAS PEDIÁTRICAS E DAS DIETAS ENTERAIS}

\author{
Nancy Yukie Yamamoto Tanaka \\ Orientador: Prof. Dr. Julio Sergio Marchini \\ Dissertação de Mestrado apresentada em 07/01/2009
}

Com o propósito de uma administração eficiente, as unidades de alimentação e nutrição têm procurado na informática uma aliada capaz de contribuir na redução dos custos e na gestão da qualidade. Este estudo objetivou avaliar os impactos sobre os custos e benefícios decorrentes da implementação da integração entre a Prescrição Eletrônica das Fórmulas Pediátricas e das Dietas Enterais e a Seção de Lactário. A coleta de dados foirealizada em duas etapas, antes (fase 1) e após (fase 2) a implementação do novo módulo. Na fase anterior às mudanças, foi feito diagnóstico da situação por meio de umquestionário baseado no instrumento SERVQUAL. Para análise comparativa do consumo quantitativo e financeiro, foram levantados dados nos dois períodos, por meio da verificação da quantidade real utilizada de produtos alimentícios, em relação ao consumo gerado pelas demandas: prescrições médicas das fórmulas, demandas rastreáveis (solicitações extras, margem de segurança, atendimento ambulatorial e domiciliar) e demandas não rastreáveis (diferença entre o consumo real e a soma do consumo decorrente das prescrições e das demandas rastreáveis). Os resultados da primeira fase mostraram que o controle da produção e da dispensação das fórmulas precisava ser melhorado, o que foi reforçado pela avaliação da percepção dos profissionais responsáveis pela assistência do paciente que diagnosticou a necessidade de intervenção nos aspectos relacionados aos processos de coleta de prescrições, dispensação das fórmulas e desperdícios. Os resultados comparativos mostraram que, na segunda fase, observou-se um controle mais efetivo das quantidades a serem produzidas, dos produtos finais dispensados, diminuindo tanto a demanda rastreável como, principalmente, a demanda não rastreável que apresentou uma redução de $85 \%$ em termos financeiros, passando de $\mathrm{R} \$ 3.770,25 /$ mês, no ano de 2007, para R \$566,73/mês, em 2008. A mudança representou não só um avanço tecnológico, com recursos que favorecem a melhoria da qualidade do serviço prestado, como também contribuiu para maior controle de todo o processo e para a redução de desperdícios. 


\title{
USO DO QUANTIPLEX BDNA ${ }^{\circledR}$ PARA QUANTIFICAÇÃO DO RNA DO HIV-1 EM SALIVA DE PACIENTES PORTADORES DO HIV-1/AIDS
}

\author{
Paula Payão Ovidio \\ Orientadora: Prof $^{\mathrm{a}}$. Dr ${ }^{\mathrm{a}}$. Alcyone Artioli Machado \\ Dissertação de Mestrado apresentada em 07/01/2009
}

A quantificação de RNA do Vírus da Imunodeficiência Humana tipo 1 (HIV-1), também chamada de carga viral, avalia a quantidade de partículas virais presentes no sangue de um indivíduo infectado por HIV-1. Esta detecção está relacionada ao estágio da infecção, ao risco de evolução para a aids e à eficácia do tratamento anti-retroviral. Níveis mais elevados de carga viral estão associados a um maior risco da evolução para a doença, enquanto níveis mais baixos correlacionam-se a menor risco de progressão clínica. Um dos testes utilizados para quantificar a carga viral de um paciente soropositivo para HIV-1 emprega biologia molecular, e é conhecido como QUANTIPLEX-bDNA ${ }^{\circledR}$. O método bDNA permite a quantificação do vírus apenas em plasma. O presente estudo avaliou a utilização do QUANTIPLEX-bDNA ${ }^{\circledR}$ em saliva, e correlacionou dados clínicos dos pacientes com os resultados obtidos. A análise foi realizada por comparação entre a carga viral plasmática e a carga viral salivar e análises de dados dos pacientes obtidos por análise dos prontuários. Para tal foram selecionados 59 pacientes infectados pelo HIV-1 em seguimento no Hospital das Clínicas da Faculdade de Medicina de Ribeirão Preto da Universidade de São Paulo, com idade maior que 18 anos e sem lesões visíveis na cavidade oral. Colheu-se de cada paciente uma amostra de sangue para obtenção do plasma e uma amostra de saliva por salivação espontânea. Para afastar a possibilidade de falso resultado no exame realizado em saliva, procedeu-se à pesquisa de sangue oculto nesse fluido, baseado na reação de Meyer. Os resultados demonstraram que cargas virais plasmáticas e salivares encontram- se diminuídas em pacientes que fazem uso de anti-retrovirais quando comparadas com as cargas virais de pacientes que não fazem uso dos mesmos, porém a quantidade de ARVs administrados parece não interferir no número de linfócitos $\mathrm{T} \mathrm{CD}^{+}$; apresentou relação com a carga viral salivar e carga viral plasmática, apesar de ter sido encontrada menor carga viral plasmática em pacientes que apresentam maior contagem de linfócitos T CD4+; quanto ao teste de sangue oculto na saliva, apenas três pacientes apresentaram positividade, com resultados de carga viral variados, e, dada a pequena casuística, não podemos fazer conclusões sobre o comportamento da carga viral em pacientes com positividade para tal teste; 27 pacientes apresentaram cargas virais, salivar e plasmática semelhantes, 16 pacientes apresentaram carga viral salivar menor que a carga viral plasmática e 16 pacientes apresentaram carga viral salivar maior que a carga viral plasmática, e a correlação entre as cargas virais, plasmática e salivar, foi significante $(\mathrm{r}=\mathrm{O}, 64$ e p<0,0001). Conclui-se que o método Quantiplex ${ }^{\circledR}$ HIV-1 RNA (bDNA) é eficiente para a detecção de carga viral do HIV-1 em saliva de indivíduos portadores do HIV-1/aids, podendo a saliva ser um fluido alternativo para a pesquisa de carga viral. Os antiretrovirais alteram a carga viral do HIV-1 tanto em plasma como em saliva, diminuindo seu valor, de maneira não associada com a quantidade de drogas administradas.

\section{ASSOCIAÇÃO ENTRE ANORMALIDADES NO SPECT E NA RESSONÂNCIA MAGNÉTICA CEREBRAL EM PACIENTES COM LES NEUROPSIQUIÁTRICO ATIVO}

\author{
Matheus Staufackar Carlos \\ Orientador: Prof. Dr. Paulo Louzada Junior \\ Dissertação de Mestrado apresentada em 19/01/2009
}

O acometimento primário do sistema nervoso lúpus eritematoso sistêmico (LESNP) é uma manifestação clínica bastante prevalente. Apesar dos recentes avanços com o uso de biomarcadores e de exames de imagem para o diagnóstico de LESNP, o seu diagnóstico de certeza continua sendo um desafio na prática diária. Nosso objetivo foi avaliar se há associação de um exame de imagem anatômico, como a ressonância magnética (RM), e um exame de imagem funcional/ perfusional, como o SPECT (single-photon emission computed tomography), com o quadro clínico de pacientes lúpicos com sintomas neuropsiquiátricos. Em adição, avaliar se há associação do perfil de auto-anticorpos, da atividade da doença e do índice de dano da doença com os exames de imagem e com as manifestações clínicas. Foram avaliados 85 pacientes com diagnóstico de LES e com suspeita de LESNP, sendo que somente 29 apresentaram confirmação diagnóstica de LESNP. A partir deste grupo foram realizados avaliação clínica, determinação de auto-anticorpos (anti-DNA, antinucleossomo, anticardiolipina, antiBeta2glicoproteínaI, antiP-ribossomal e anticorpos antilinfocitotóxicos) e exames de imagem (SPECT e ressonância cerebral). Todos os auto-anticorpos foram determinados por ELISA. A atividade da doença foi medida pelo SLEDAI (Systemic Lupus Erythematosus Disease Activity Index) e o índice de lesão tecidual pelo SLICC/ACR (Systemic Lupus International Collaborating Clinics Damage Index aprovado pelo American College of Rheumatology). Foi obser- 
vada uma associação positiva entre o quadro clínico dos pacientes e as alterações observadas no SPECT cerebral (97,4\%, contra 54,5\% da RM). Em relação à RM, também foi observada xii uma grande frequência de alterações estruturais do SNC, apesar delas não estarem associadas com as manifestações clínicas presentes no momento da internação. Não foi observada nenhuma associação entre auto-anticorpos e manifestação clínica, bem como com alterações observadas nos exames de imagem. O emprego combinado de dois exames de imagem, como a RM e o SPECT, em face de um quadro clínico bem caracterizado, representa uma conduta de grande valia diagnóstica para o paciente com suspeita de LESNP. Nenhum dos auto-anticorpos avaliados mostraram especificidade com a ocorrência de manifestações neuropsiquiátricas do LES.

\title{
ANÁLISE DO VOLUME CEREBRAL EM PACIENTES COM LÚPUS ERITEMATOSO SISTÊMICO OBTIDO A PARTIR DE IMAGENS DE RESSONÂNCIA MAGNÉTICA
}

\author{
Rodrigo de Oliveira \\ Orientador: Prof.Dr. Paulo Louzada Junior \\ Dissertação de Mestrado apresentada em 19/01/2009
}

Introdução: A presença de atrofia cerebral nos pacientes lúpus eritematoso sistêmico (LES) é bastante prevalente, principalmente naqueles com manifestação neuropsiquiátrica (LESNP). Objetivos: Avaliar o volume cerebral de pacientes com LES com e sem manifestações neuropsiquiátricas por imagens de ressonância magnética, na ausência de lesões vasculares focais. Secundariamente, identificar fatores preditivos de atrofia cerebral em pacientes com LES com e sem manifestações neuropsiquiátricas. Pacientes e Métodos: Um total de 58 pacientes foram avaliados, dos quais 35 com LESNP e 23 com LES sem acometimento neuropsiquiátrico (LESnNP). Foi feito avaliação clínica, determinação de anticorpos (antiDNA, anticardiolipina, anti- $\beta 2$ - glicoproteina1 e pesquisa de inibidor lúpico e anti-SM) por ELISA, determinação da dose diária de corticosteróides e realização de ressonância magnética (IRM) da qual imagens ponderadas em T1 foram utilizadas para realização de volumetria através do programa SPM99®. As IRM de um grupo de 61 indivíduos saudáveis foram utilizadas como controle. A atividade da doença foi medida pelo SLEDAI (Systemic x Lupus Erythematosus Disease Activity Index) e o índice de lesão tecidual pelo SLICC/ACR (Systemic Lupus International Collaborating Clinics Damage Index aprovado pelo American College of Rheumatology). Resultados: Os pacientes LESNP apresentam redução de substância branca e de volume de parênquima cerebral em comparação aos pacientes LESnNP e controles saudáveis ( $\mathrm{p}<0,001)$. Esses achados estão associados a maior prevalência de anticorpos antifosfolípides $(77,1 \%$ vs 39,1\%, p<0,005), índice de danos $(\mathrm{p}<0,0001)$ e dose diária de corticosteróide $(\mathrm{p}<0,03)$. O subgrupo de pacientes LESNP com convulsão e/ou doença cérebrovascular têm maior perda de volume cerebral comparado ao grupo de pacientes LESNP sem convulsão e/ou doença cerebrovascular $(\mathrm{p}<0,001)$. Os pacientes LESNP apresentam maior número de anormalidades às imagens de IRM $(82,8 \%)$, porém com correlação clínica (hipótese localizatória) baixa $(37,1 \%)$. Conclusão: O acometimento neuropsiquiátrico pelo LES associa-se a perda de substância branca e redução de volume cerebral. Esses achados também estão associados à presença de anticorpos antifosfolípides, corticosteróides e danos crônicos acumulados e, parece ser mais importante no subgrupo de pacientes com convulsão e/ou doença cerebrovascular. A IRM apresenta boa sensibilidade e baixa especificidade para o diagnóstico de LESNP.

\section{A ENZIMA PLD1 É IMPORTANTE PARA A MANUTENÇÃO ESTRUTURAL E FUNCIONAL DO COMPLEXO DE GOLGI EM MASTÓCITOS}

Liliana Martos Nicoleti

Orientadora: Prof ${ }^{\mathrm{a}}$. Dra ${ }^{\mathrm{a}}$. Constance Oliver

Tese de Doutorado apresentada em 22/01/2009

Fosfolipase D (PLD) é uma enzima que catalisa a hidrólise da fosfatidilcolina em colina e ácido fosfatídico, um lipídeo que atua como um mensageiro secundário. A PLD participa de vários processos celulares, sendo ativada por diferentes receptores da superfície celular. Neste estudo, a estrutura do complexo de Golgi foi examinada em linhagens estabilizadas para a superexpressão da forma catalítica ativa (PLD1CA) e inativa (PLD1CI) da enzima PLD1. Através de microscopia eletrônica de transmissão observa-se que as células PLD1CI apresentam o complexo de Golgi bem desenvolvido em comparação com as células PLD1CA. Nas células PLD1CA, o complexo de Golgi possui cisternas finas e se encontra mais disperso no citoplasma. As vesículas recobertas com COP de células PLD1CA possuem atividade de PLD, estas vesículas participam do transporte no complexo de Golgi. As vesículas recobertas com COP, das células PLD1CI, não possuem atividade PLD, o que pode estar relacionado com a desorganização estrutural desta organela. Em células PLD1CI os grânulos secretores estão restritos ao corpo celular, enquanto nas células PLD1CA também são encontrados nos prolongamentos. Os grânulos das células PLD1CI só são observados nos prolongamentos quando as células são estimuladas via FceRI. As células PLD1CI quando tratadas com tratamento com ácido fosfatídico, passam a apresentar o fenótipo 
semelhante ao das células PLD1CA. Portanto, o ácido fosfatídico está envolvido na manutenção estrutural do complexo de Golgi e no trânsito de grânulos. A GTPase ARF está envolvida no recrutamento das cobertas de vesículas, enquanto a GTPase Rho regula o citoesqueleto de actina. Ambas GTPases também regulam a atividade de PLD. Alto nível de expressão de RhoA foi detectado nas células PLD1CI. Ainda, uma interação direta entre PLD1 e RhoA foi observada nas células PLD1CA. Este conjunto de resultados mostram que a enzima PLD1 participa da manutenção estrutural do Golgi e do trânsito de grânulos secretores. O entendimento mais avançado do papel da enzima PLD1 em mastócitos poderão levar a novas estratégias terapêuticas para controlar a ativação dos mastócitos durante processos alérgicos e inflamatórios.

\title{
AVALIAÇÕES CELULARES DO ESCARRO INDUZIDO DE ASMÁTICOS APÓS BRONCOPROVOCAÇÃO COM SOLUÇÃO SALINA HIPERTÔNICA
}

\section{Silvia Maria Romão Pontes}

Orientador: Prof. Dr. Elcio dos Santos Oliveira Vianna

Dissertação de Mestrado apresentada em 26/01/2009

A asma se caracteriza por obstrução reversível das vias aéreas, inflamação eosinofílica e hiperreatividade brônquica, e esta última pode ser avaliada por um teste de broncoprovocação. A solução salina hipertônica (SSH) é um estímulo indireto utilizado para medir a reatividade brônquica e seu uso já está estabelecido em asmáticos. A indução do escarro (IE), que também se utiliza da SSH, é um método simples, seguro e reprodutível para mensuração da inflamação das vias aéreas. A broncoconstricção por SSH vem sendo explicada por uma série de mecanismos inflamatórios, físicos e neuronais, não totalmente estabelecidos e, provavelmente, de etiologia multifatorial. A inalação sequencial de SSH reduz a resposta broncoconstritora, sendo este fenômeno denominado período refratário. As causas desse fenômeno ainda não estão estabelecidas. A broncoprovocação com SSH e a IE são, atualmente, instrumentos importantes no campo da pesquisa em asma, e os fenômenos que envolvem esses dois procedimentos vem sendo estudados nas últimas décadas. Os objetivos do presente estudo foram: verificar possíveis alterações do componente celular do escarro induzido de asmáticos submetidos à broncoprovocação com SSH, e testar correlação entre o componente celular e a presença de refratariedade à SSH. Foram estudados 21 pacientes asmáticos, sendo 17 do sexo feminino, estáveis, idade (média \pm DP) de $39 \pm 10$ anos e VEF1 (\%) de 86,0 $\pm 7,5 \%$, em uso de beclometasona inalatória. Os pacientes, incialmente, eram submetidos à indução de escarro para obtenção do escarro induzido basal. Após 14 a 20 dias, os pacientes eram submetidos ao teste de broncoprovocação com SSH e, 48 horas após, eram submetidos à nova indução de escarro (escarro estudo). Para pesquisa da presença e intensidade do período refratário, 17 pacientes foram submetidos, após 14 a 20 dias da segunda indução, a duas novas broncoprovocações com SSH, separadas por um intervalo de $48 \mathrm{~h}$. Em relação à composição celular, o escarro estudo não diferiu do escarro basal, não havendo diferença no número percentual (mediana -IQR) de eosinófilos $(6,0$ [2,5-8,0] para 7,5 $[2,0-12,5], p=0,58)$, neutrófilos $(34,0$ [27,0-42,5] para 35,0 [20,5-44,5], p = 0,75), linfócitos $(5,25$ [3,0-7,5] para 5,75 [3,0-8,5], p $=0,81$ ou macrófagos $(54,5[38,5-58,5]$ para 53,7 [42,0-71,0], p = 0,54). Não houve correlação entre a refratariedade e a constituição celular $(\mathrm{r}=-0,24 ; \mathrm{p}=0,34)$. Os fenômenos responsáveis pelo período refratário não se associam a mudanças na constituição celular, não sendo possível atribuir a nenhum grupo celular a sua presença ou intensidade. Portanto, concluímos não haver alterações no diferencial de células após 48 horas da inalação da solução salina e não haver correlação entre a refratariedade e a constituição celular do escarro induzido.

\section{CARACTERIZAÇÃO ULTRA-SÔNICA TECIDUAL MIOCÁRDICA NA CARDIOPATIA INDUZIDA PELA DOXORRUBICINA: ESTUDO EXPERIMENTAL ANIMAL}

\author{
Minna Moreira Dias Romano \\ Orientador: Prof. Dr. Benedito Carlos Maciel \\ Tese de Doutorado apresentada em 03/02/2009
}

A doxorrubicina (DXR) é utilizada no tratamento de várias doenças neoplásicas, sendo seu uso limitado pela cardiotoxicidade. Limites empíricos de doses acumuladas da medicação são definidos, mas o acompanhamento seriado da fração de ejeção de ventrículo esquerdo (FEVE) garante segurança adicional, tendo em vista a variabilidade individual na incidência de disfunção ventricular esquerda. Porém, a FEVE tem baixa sensibilidade em detectar a cardiotoxicidade em doses baixas da medicação. Para avaliar se a Caracterização Ultra-sônica Tecidual (CUT) é capaz de identificar precocemente as alterações miocárdicas secundárias ao uso da DXR, e se esta se correlaciona com o conteúdo de colágeno miocárdico, foram estudados 70 ratos, dos quais 60 receberam infusões endovenosas semanais de $2 \mathrm{mg} / \mathrm{Kg}$ de DXR até dose acumulada de $16 \mathrm{mg} / \mathrm{Kg}$ e 10 receberam salina. Ecocardiografia bidimensional convencional foi realizada nos animais sedados na situação basal e 7-15 dias após as doses acumuladas de 8,10,12,14 e 16mg/Kg de DXR ou após infusão de salina no grupo controle, com mensuração da FEVE e da fração de encurtamento (Delta D). Os índices de CUT: coeficiente 
corrigido do "Integrated backscatter" (CC-IBS) e magnitude da variação cíclica (MVC) foram também obtidos. Para cálculo do CC-IBS foi dividido o valor de intensidade do IBS obtido no tecido pelo medido em um "phantom" de borracha, mantendo constantes ajustes do sistema de ultra-som e profundidade. Sete animais que receberam salina e 24 que receberam DXR (nas doses de 8, 12 e $16 \mathrm{mg} / \mathrm{Kg}$ ) foram sacrificados para cálculo da porcentagem de colágeno miocárdico. Para cada animal, calculou-se o coeficiente beta da regressão linear de cada variável estudada em função das doses avaliadas. Este coeficiente foi utilizado nas análises não-paramétricas de comparação entre variáveis contínuas (correlação de Spearman) e categóricas (Teste de Kruskal-Wallis), com significância de 5\%. Houve correlação entre o CC-IBS e a porcentagem de colágeno $(r=0,45 ; p=0,02)$, o que não ocorreu para fração de ejeção $(r=-0,2 ; p=0,33)$, Delta $D(r=-0,09$; $p=0,65)$, e MVC ( $r=0,06 ; p=0,76)$. A FEVE diminuiu discretamente $(80,4 \pm 6,9 \%$ x 85,3 $\pm 6,9 \%$ na situação basal, $p=0,005)$ a partir da dose de $8 \mathrm{mg} / \mathrm{Kg}$ de DXR, com nova redução $(76,4 \%, \mathrm{p}=0,05)$ na dose de $12 \mathrm{mg} / \mathrm{Kg}$ de DXR. O CC-IBS foi maior a partir da dose de $8 \mathrm{mg} / \mathrm{Kg}$ de DXR em relação ao basal $(1,29 \pm 0,27$ x 1,1 $\pm 0,26 ; \mathrm{p}=0,005)$, com novo incremento na dose de $12 \mathrm{mg} / \mathrm{Kg}(1,44 \pm$ $0,18 \times 1,1 \pm 0,26 ; \mathrm{p}=0,001)$. A MVC diminuiu a partir da dose de $8 \mathrm{mg} / \mathrm{Kg}$ em relação ao basal $(9,1 \pm 2,8 \times 11,02 \pm 2,6 ; \mathrm{p}=0,006)$ mantendo valores semelhantes posteriormente. O CC-IBS mostrou sensibilidade de $72,2 \%$ e especificidade de $83,3 \%$ em detectar fibrose correspondente a 4,24\% de colágeno. Em conclusão: 1) não obstante a FEVE (redução<6\%) e CC-IBS apresentarem alterações significativas já com a dose de $8 \mathrm{mg} / \mathrm{Kg}$, as alterações de CC-IBS foram mais marcantes (incremento>20\%); 2) MVC apresentou redução significativa com a dose de $8 \mathrm{mg} / \mathrm{Kg}$, estabilizando-se a partir daí; 3) apenas CC-IBS mostrou correlação significativa com a porcentagem de colágeno miocárdico; 4) CC-IBS mostrou boa acurácia para a detecção precoce de fibrose miocárdica neste modelo experimental animal.

\section{PERFIL FRAMACOCINÉTICO DO BUSSULFANO E ASSOCIAÇÃO COM A RESPOSTA CLÍNICA EM PACIENTES SUBMETIDOS A TRANSPLANTE DE CÉLULAS TRONCO HEMATOPOÉTICAS}

Francine Attié de Castro

Orientadora: Prof ${ }^{\mathrm{a}}$. Dr ${ }^{\mathrm{a}}$. Belinda Pinto Simões

Dissertação de Mestrado apresentada em 04/02/2009

O bussulfano (1,4-butanodiol dimetanosulfonato) é um agente alquilante bifuncional comumente administrado em associação com a ciclofosfamida (CY) ou a fludarabina (FLU) em regime de condicionamento pré-transplante de células tronco hematopoéticas. A farmacocinética do bussulfano (BU) quando associado à FLU é pouco conhecida, especialmente quando essa associação é feita com BU oral. Alguns estudos relatam que o tratamento preconizado de BU (16 doses de $1 \mathrm{mg} / \mathrm{Kg}$ de 6 em 6 horas, administradas oralmente ou $0,8 \mathrm{mg} / \mathrm{Kg}$ na forma endovenosa) está associado ao risco de graves toxicidades, a diminuição da sobrevida e para alguns pacientes o tratamento não atinge o efeito mielossupressor necessário. No presente trabalho, um ensaio sensível e específico, baseado na análise por cromatografia liquida de alta eficiência, com detecção de luz ultra-violeta, foi validado para analisar BU em amostras de plasma humano. A resposta do detector foi linear dentro da faixa estudada, $0,1-5 \mu \mathrm{g} / \mathrm{mL}$, com r $>0,99$ e tempo de análise de 16 minutos. A precisão intra e inter-ensaio apresentaram valores dentro dos especificados pela ANVISA e o limite de quantificação foi de $100 \mathrm{ng} / \mathrm{mL}$. Amostras plasmáticas de 26 pacientes foram analisadas e as concentrações plasmáticas médias (Css) foram associadas às suas respostas clínicas. Dois diferentes protocolos foram utilizados, BU associado à CY e BU associado à FLU (BUCY e FLUBU), e comparados. Vinte e seis pacientes portadores de doenças onco-hematológicas com idade média de 32 anos (intervalo, 15-57 anos) foram incluídos no estudo. Onze pacientes fizeram parte do protocolo FLUBU e 15 do BUCY. A Css de BU sugerida é de 600-900 ng/mL, no grupo de pacientes que recebeu FLUBU a Css observada foi 1275,4 ng/mL e no grupo BUCY foi 966,4 ng/mL. Importantes variações inter-paciente nas concentrações de BU foram identificadas durante o regime de condicionamento. Não foi encontrada associação entre a Css do BU e toxicidade do transplante de células tronco hematopoéticas. No protocolo FLUBU observou-se redução no "clearance" do BU quando comparado com pacientes do grupo BUCY. Conclui-se que a variabilidade inter-paciente limita a aplicação de modelos farmacocinéticos para previsão de concentrações e sugere-se a individualização de doses nos dois tipos de protocolos estudados.

\section{ESTUDO DA REPETIBILIDADE E DA REFRATARIEDADE DA BRONCOPROVOCAÇÃO COM SOLUÇÃO SALINA HIPERTÔNICA NA ASMA}

\section{Érica Ferraz}

Orientador: Prof. Dr. Elcio dos Santos Oliveira Vianna

Tese de Doutorado apresentada em 17/02/2009

A hiper-reatividade brônquica é uma das principais características da asma, sendo um estreitamento exagerado das vias aéreas em resposta a estímulos inespecíficos, que não causariam estreitamento em indivíduos normais. Dentre os 
métodos usualmente empregados para avaliar a hiper-reatividade, temos a broncoprovocação com solução salina hipertônica (SSH). Após um teste de broncoprovocação, segue-se um período refratário, durante o qual o paciente deixa de ser reativo ou passa a ser menos reativo. Os objetivos deste presente estudo foram avaliar a repetibilidade do teste de broncoprovocação com SSH e metacolina (MET) em 2 semanas em asmáticos que fizeram ou não inalações repetidas de SSH, que usavam ou não corticosteroide inalatório (CI), além de avaliar os efeitos da refratariedade nos parâmetros clínicos da asma. Quarenta voluntários (VEF) entre 60 e 85\%) foram submetidos a broncoprovocações com SSH nos dias 1, 15 e 29 para testar a repetibilidade. Um subgrupo $(\mathrm{n}=20)$ submeteu-se a 5 outras broncoprovocações com SSH, entre os dias 15 e 29 , "com intervalo de 48 ou 72 horas entre elas e no mesmo horário do dia. Dos 40 voluntários, 25 faziam uso de CI. A broncoprovocação consistiu de inalações de $\mathrm{NaC} 14,5 \%$ com durações crescentes $(0,5 ; 1 ; 2 ; 4$ e 8 min) até a queda de $15 \%$ do VEF) ou até 15,5 min de inalação. A razão dose-resposta (RDR) foi calculada pela divisão da queda de $\mathrm{VEF}_{1}$ (em porcentagem) medida ao [mal do teste pelo volume total de SSH. Outros 16 voluntários foram submetidos a broncoprovocações com MET nos dias 1, 15 e 29 para testar a repetibilidade. A broncoprovocação com MET foi realizada

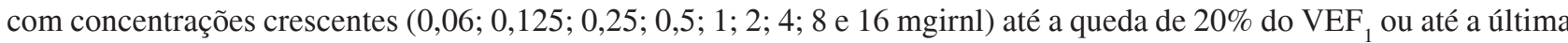
concentração inalada. A concentração provocadora da queda de $20 \%$ do $\mathrm{VEF}_{1}\left(\mathrm{PC}_{20}\right)$ foi calculada. No grupo SSH, a broncoconstrição do dia do dia 15 , média da RDR dia $1=5,13 \pm 3,15$ e dia $15=4,15 \pm 3,35$, diferença significativa $(p=0,02)$ pelo teste de Wilcoxon e 0,68 pelo coeficiente de concordância de Lin (CCL). Entre os dias 15 e 29, a RDR diminuiu em ambos os grupos, no grupo que não fez inalações repetidas de SSH e no grupo que se submeteu a inalações repetidas. No grupo MET, a PC20 manteve-se durante todo o estudo, não houve diferença significativa e apresenta boa repetibilidade entre os dias 1 e $15(\mathrm{CCL}=0.87)$. Não houve efeito das provocações repetidas nos parâmetros clínicos da asma. Concluindo, não há boa repetibilidade do teste de broncoprovocação com SSH em 2 semanas. A falta de repetibilidade pode ser devido à refratariedade causada pelo método, e a repetição de testes a cada 48 horas ao longo de 2 semanas não causa refratariedade adicional.

\title{
CITOTOXICIDADE INDUZIDA PELA ASSOCIAÇÃO DE PEROXIDASE COM ÁCIDO 3-INDOL-ACÉTICO EM NEOPLASIAS HEMATOLÓGICAS
}

\author{
Leandro Felipe Figueiredo Dalmazzo \\ Orientador: Prof. Dr. Roberto Passetto Falcão \\ Dissertação de Mestrado apresentada em 18/02/2009
}

O ácido 3-indol-acético (IAA), um hormônio de crescimento vegetal, quando oxidado pela horseradish peroxidase (HRP), gera moléculas citotóxicas capazes de lesar células de mamíferos. Foi demonstrado que a associação de IAA/HRP possui efeitos tóxicos a diversos tumores humanos. Nosso objetivo foi criar um modelo de direcionamento da HRP a células de neoplasias hematológicas através de anticorpos e avaliar a indução de apoptose nas mesmas. Foram utilizadas duas linhagens de neoplasias hematológicas: NB4, de leucemia promielocítica aguda (LPA), e Granta 519, de linfoma nãoHodgkin da zona do manto. Foram também utilizadas células de 12 pacientes com diagnóstico de leucemia mielóide aguda (LMA), sendo que seis eram portadores de LPA, e de 10 pacientes portadores de leucemia linfocítica crônica (LLC). O direcionamento da ação da HRP foi feito através da incubação com anticorpo anti-CD33 (na LMA e linhagem NB4) ou antiCD19 (na LLC e linhagem Granta 519), seguido da incubação com anticorpo GAM (goat anti-mouse), conjugado à HRP. Oito grupos celulares foram colocados em cultura: controles, marcadas com HRP, marcadas com HRP e acrescidas de IAA nas doses 1,5 e 10 mM, e não marcadas com HRP acrescidas de IAA nas doses acima. A análise de apoptose foi feita por citometria de fluxo, utilizando marcação com anexina V-FITC e iodeto de propídio. Na linhagem NB4, com oito horas de cultura, apenas as células incubadas com HRP e tratadas com $10 \mathrm{mM}$ de IAA apresentaram maiores taxas de apoptose (média de 32,2\%) ( $\mathrm{p} \leq 0,05)$. Com 18 horas de cultura, os grupos incubados com HRP e tratados com 5 e $10 \mathrm{mM}$ de IAA apresentaram, respectivamente, taxas médias de apoptose de 52,3 e 32,2\%, sendo que os grupos controles apresentaram taxas variando de 10,2 a 15, 7\% (p $\leq 0,05)$. Nos tempos de 24 e 48 horas, os três grupos incubados com HRP e tratados com IAA apresentaram taxas de apoptose significativamente maior comparados aos controles ( $\mathrm{p} \leq 0,05)$. Na linhagem Granta 519, a partir do período de 8 horas de exposição, já foram observadas maiores taxas de apoptose nas células incubadas com HRP e expostas a 1, 5 e $10 \mathrm{mM}$ de IAA (respectivamente, 25.2, 31.8 e 41.3\%, sendo que os controles mostraram taxas que variaram de 13.1 a 15.6\%) ( $\mathrm{p} \leq \mathrm{O}, \mathrm{O} 5)$. Com 18, 24 e 48 horas de cultura, a porcentagem de morte celular nos grupos incubados com HRP e tratados com IAA variou de 58.5 a $72.3 \%$, valores superiores aos encontrados nos controles (p $\leq$ $\mathrm{O}, \mathrm{O5})$. Os resultados nas amostras de pacientes com LMA foram bastante semelhantes aos descritos para as linhagens celulares. Nas amostras de pacientes com LPA, só houve maiores taxas de apoptose que nos controles nos grupos incubados com HRP e tratados com 5 e $10 \mathrm{mM}$ de $1 \mathrm{M}$. O grupo tratado com $10 \mathrm{mM}$ de $1 \mathrm{M}$ e não marcado com HRP também 
apresentou maiores taxas de apoptose quando comparado aos outros controles $(\mathrm{p}<\mathrm{O}, \mathrm{O} 5)$, mostrando que a mieloperoxidase encontrada nos blastos desses pacientes foi capaz de ativar o IAA, na ausência da HRP. Nas células de LLC submetidas a 24 horas de cultura, as taxas médias de apoptose com 1, 5 e 10 mM de IAA foram de 58,5, 81,3 e 93,3\%. Nos grupos controles, as taxas variaram de 35,7 a 53,7\% ( $<<\mathrm{O}, \mathrm{O} 5)$. Esses resultados demonstram que o modelo de direcionamento enzimático da HRP através de anticorpos conjugados foi efetivo para ativar o IAA e causar apoptose. A associação IAA/HRP foi capaz de induzir apoptose em neoplasias hematopoéticas, o que mostrou ser dependente da dose de IAA utilizada e do tempo de exposição ao ácido.

\title{
ASSOCIAÇÃO ENTRE DIABETES MELLITUS, PRÉ-DIABETES E DOENÇA DE ALZHEIMER
}

\author{
Jarbas de Sá Roriz Filho \\ Orientador: Prof. Dr. Júlio César Moriguti \\ Tese de Doutorado apresentada em 20/02/2009
}

Diabetes mellitus (DM) e pré-Diabetes (PD) têm sido implicados como fatores de risco para demência não apenas vascular, mas também para doença de Alzheimer (DA). Esse estudo teve como objetivo avaliar a presença de alterações cerebrais estruturais e metabólicas em pacientes com PD, DM e DA, utilizando Ressonância Magnética (RM) cerebral quantitativa e bateria de testes neuropsicológicos, investigando a associação entre essas condições e considerando a influência da Hipertensão Arterial Sistêmica (HAS). Foram incluídos no estudo 64 voluntários, de ambos os sexos, idade entre 60 e 75 anos, divididos em seis grupos: DA ( $n=10)$, DM + HAS ( $n=12)$, DM sem HAS (n=13), PD+HAS (n=10), PD sem HAS ( $n=9)$ e Controle (NC) $(n=10)$. Os voluntários foram submetidos ao exame de RM seguido de quantificação tecidual das percentagens de substância cinzenta (PSC) e branca (PSB), da fração de parênquima cerebral (BPF), da análise do tempo de relaxação (relaxometria) e da transferência de magnetização (MT), além da quantificação de metabólitos cerebrais pela espectroscopia de prótons. Os grupos foram comparados utilizando-se análise de variância (ANOVA). Os resultados mostraram que o grupo DA foi discriminado do controle pelas medidas de PSC ( $<<0,01)$, BPF ( $<<0,01)$, relaxometria da SC $(\mathrm{p}<0,01)$ e da SB $(\mathrm{p}<0,01)$, e MT da SC $(\mathrm{p}<0,02)$ e da SB $(\mathrm{p}<0,01)$. O grupo DM+HAS foi discriminado do controle pelo BPF $(\mathrm{p}<0,01)$, relaxometria da SC $(\mathrm{p}<0,01)$ e da SB $(\mathrm{p}<0,01)$, e MT da SC $(\mathrm{p}<0,01)$ e da $\mathrm{SB}(\mathrm{p}<0,03)$. A MT da SB discriminou o grupo DM do controle $(\mathrm{p}<0,01)$. As variáveis estruturais estudadas não mostraram diferença significativa entre os grupos de pré- diabetes (PD+HAS ou PD) e o controle. A relaxometria da SC discriminou os grupos DA e DM+HAS (p<0,04). A PSC $(\mathrm{p}<0,01)$, e as relaxometrias da SC $(\mathrm{p}<0,01)$ e da SB $(\mathrm{p}<0,02)$ discriminaram o grupo DA do DM. Os grupos PD+HAS e PD mostraram diferença quando comparados ao DA nas seguintes (PD+HAS e PD com $\mathrm{p}<0,01$ ); relaxometria da SC (PD+HAS; $\mathrm{p}<0,02)$ e (PD; $\mathrm{p}<0,01)$; relaxometria da SB (PD; $<<0,01)$; MT da SC (PD+HAS; $<<0,03)$ e $(P D ; p<0,04)$ e MT da SB $(\mathrm{PD}+\mathrm{HAS} ; \mathrm{p}<0,02)$ e (PD; $<<0,04)$. Não houve diferença estatisticamente significante na comparação dos resultados da espectroscopia de prótons entre os grupos analisados. Os pacientes com DM+HAS apresentaram déficit cognitivo caracterizado por prejuízo na atenção e funções executivas, identificado pelo teste de Stroop na comparação com NC. A DA é caracterizada por alterações degenerativas predominantemente corticais, mas também em SB subcortical de cunho vascular. A RM quantitativa se mostra mais sensível em diagnosticar alterações histológicas cerebrais e permite avaliar a integridade da mielina. A RM quantitativa se mostrou útil em diferenciar pacientes normais de portadores de DA e os achados sugerem uma associação entre PD, DM e DA.

\section{QUALIDADE DE VIDA RELACIONADA À SAÚDE DE IDOSOS DE PEQUENA COMUNIDADE DO INTERIOR DE SÃO PAULO}

\author{
Daniela Cristina Lojudice \\ Orientador: Prof. Dr. Julio Cesar Moriguti \\ Tese de Doutorado apresentada em 02/03/2009
}

O envelhecimento traz consigo modificações importantes na vida do ser humano, predispondo-o ao surgimento de doenças que, de uma forma geral, criam consequências variadas na vida do idoso, limitando a sua capacidade funcional e reduzindo a sua qualidade de vida. Os objetivos deste estudo foram caracterizar a população idosa do município de Monções-SP, avaliar e descrever a Qualidade de Vida Relacionada à Saúde (QVRS) dos idosos, assim como identificar as relações entre a QVRS e os fatores sociodemográficos, econômicos e clínicos. Trata-se de um estudo seccional e populacional com 277 idosos, sendo 56,6\% do sexo feminino. A idade dos idosos variou de 60 a 90 anos, com média de 69,8 7 7,67 anos para o sexo feminino e 70,18 \pm 7,54 anos para o sexo masculino. Os dados foram coletados mediante entrevista através de 
questionário sócio-demográfico e clínico; Mini Exame do Estado Mental (MEEM) e Medical Outcomes Short-Form Health Survey (SF-36). Os resultados mostraram que as dimensões do SF-36, que obtiveram menores escores médios foram: aspecto emocional $(33,83)$ e aspectos físicos $(36,50)$, enquanto que as dimensões que apresentaram maiores escores médios foram: aspectos sociais $(86,88)$ e saúde mental $(71,84)$. Os fatores que obtiveram menores escores médios para todas as dimensões do SF-36 foram: sexo, idade maior ou igual a 75 anos, ausência de atividade física, presença de 3 ou mais morbidades e uso de medicamentos. Os resultados aqui encontrados apontam para a necessidade da implementação de programas prioritários e apropriados de assistência para essa clientela, visando otimizar as dimensões da QVRS comprometidas.

\title{
POLIMORFISMOS DA LIPASE LIPOPROTÉICA E DA APOLIPOPROTEÍNA E: CORRELAÇÃO COM HIPERTRIGLICERIDEMIA NA POPULAÇÃO COM ASCENDÊNCIA JAPONESA RESIDENTE NO MUNICÍPIO DE BAURU-SP
}

\author{
Thaísa de Faria Cruz Neves \\ Orientador: Prof.Dr. José Ernesto dos Santos \\ Dissertação de Mestrado apresentada em 02/03/2009
}

Grupos populacionais com características definidas representam importante objeto de estudo para avaliação de fatores ambientais e genéticos na etiologia de algumas doenças. Diabetes melito tipo 2 (DM2) e dislipidemia (DLP) são exemplos de doenças de interesse na avaliação de tais grupos devido às marcantes diferenças geográficas e étnicas em suas taxas de prevalência. Populações com ascendência japonesa, que originariamente apresentavam baixa morbidade por DM2, após sofrer mudanças sócio-culturais, em curto período de tempo, passaram a apresentar maior risco de desenvolver essa doença. Sendo assim, essas populações constituem interessante modelo para o estudo de DM2 e doenças associadas. É sabido que dislipidemia é um dos principais fatores de risco cardiovascular em pacientes diabéticos. Hipertrigliceridemia e baixos níveis de HDL (lipoproteína de alta densidade) são perfis lipídicos fortemente associados ao DM2. Trabalhos recentes têm identificado frequentes polimorfismos e mutações nos genes da lipase lipoprotéica (LPL) e apolipoproteína E (apoE) possivelmente relacionados à hipertrigliceridemia. Os objetivos do presente estudo foram avaliar a frequência de alguns polimorfismos da LPL e apoE na população adulta com ascendência japonesa residente no município de Bauru-SP e correlacioná-los com os níveis de triglicerídeos nesta população. Correlacionar também a presença ou não dos polimorfismos citados com outros parâmetros, como diabetes melito tipo 2 e tolerância normal à glicose e aferições antropométricas. Foram avaliados 130 indivíduos, ambos os sexos, entre 30 e 60 anos de idade, à princípio divididos em dois grupos tendo como base os níveis de triglicerídeos plasmático: $\geq 400 \mathrm{mg} / \mathrm{dL}$ e $\leq 200 \mathrm{mg} / \mathrm{dL}$. Em seguida, cada grupo foi sub-dividido em diabéticos e não diabéticos. Dados antropométricos e laboratoriais foram extraídos de um banco de dados da população avaliados através da técnica de PCR. Como resultados para esta amostra, a frequência dos polimorfismos da apoE e da LPL foi semelhante à descrita na literatura em estudos envolvendo a população japonesa vivendo no Japão. Não houve associação, com significância estatística, entre as frequências dos polimorfismos avaliados e hipertrigliceridemia, nem entre a presença ou não de DM2 nos dois grupos iniciais. Nestes, os sub-grupos de diabéticos apresentaram IMC e relação cintura/ quadril mais elevados. De maneira geral, observou-se níveis mais elevados de colesterol total nos não diabéticos e não houve diferença nos níveis de HDL e LDL entre os grupos.

\section{INFLUÊNCIA DO ÁLCOOL E NÚMERO DE MEDICAÇÕES NA ADESÃO AOS ANTI-RETROVIRAIS EM PORTADORES DO HIVIAIDS}

\section{Eveline Saad deAndrade}

Orientadora: Prof ${ }^{a}$. Dr ${ }^{\mathrm{a}}$. Alcyone Artioli Machado

Dissertação de Mestrado apresentada em 05/03/2009

Introdução: A Terapia Anti-retroviral de Alta Eficácia (Highly Active Antiretroviral Therapy - HAART) é recomendada para todos os pacientes infectados pelo Vírus da Imunodeficiência Humana (HIV) que sejam sintomáticos, independente da contagem de linfócitos $\mathrm{TCD}_{4}{ }^{+}$, e para aqueles assintomáticos com contagem de linfócitos $\mathrm{TCD}_{4}{ }^{+}$abaixo de 200 células $/ \mathrm{mm}^{3}$. A adesão inadequada à terapia anti-retroviral é a causa mais frequente de falha no tratamento, pois o uso dos medicamentos em doses subótimas ou de forma irregular acelera o processo de seleção de cepas virais resistentes. O consumo de bebidas alcoólicas pode interferir no sucesso da HAART, basicamente, de duas maneiras: quando o paciente deixa de tomar a medicação para poder consumir a bebida ou quando o paciente ingere álcool junto com a medicação e este interage com a droga diminuindo seu efeito. Assim como o álcool, outro importante fator que interfere negativamente na adesão dos portadores do HIV à HAART, é o número de medicamentos a serem tomados. As atuais terapias anti-retrovirais 
têm um esquema de administração de doses bastante complexo. O grande número de comprimidos ou cápsulas, utilizados por tempo indeterminado, dificulta sobremaneira a adesão do paciente ao tratamento à longo prazo. Em casos de infecções associadas, em que são necessárias terapias combinadas, o aumento no número de comprimidos pode trazer ainda mais dificuldade na compreensão das doses. Objetivo: Verificar se o consumo de álcool e a quantidade de medicamentos ingeridos influenciam na adesão aos anti-retrovirais em portadores do HIV/aids atendidos na Unidade Especial de Tratamento de Doenças Infecciosas (UETDI) do Hospital das Clínicas da Faculdade de Medicina de Ribeirão Preto da Universidade de São Paulo (HCFMRP). População, Material e Método: Tratou-se de um estudo transversal I realizado no período de fevereiro a junho de 2007. Foram incluídos no estudo 250 pacientes adultos portadores de HIV/aids que estavam em tratamento com anti-retrovirais em seguimento no ambulatório da UETDI. Para a avaliação de variáveis possivelmente associadas à adesão à HARRT foi utilizado um questionário estruturado buscando dados relativos ao modo de aquisição do vírus, tempo de infecção pelo HIV/aids, uso de drogas ilícitas, tabagismo, álcool, tempo de início do uso dos ARV, outras medicações em uso, número de comprimidos/cápsulas/dia e respectivos horários de administração, dificuldades na tomada da medicação e frequência aos retornos. Para avaliar o consumo de álcool aplicou-se o Alcohol Use Disorder Identification Test (AUDIT) que é um questionário composto por dez questões elaborado pela Organização Mundial da Saúde (OMS) para Identificar distúrbios sobre o uso de álcool. Foram coletadas ainda informações referentes ao tratamento; frequência aos retornos e quantificação do RNA do HIV-1 e dos linfócitos $\mathrm{TCD}_{4}{ }^{+}$com o intuito de complementar os dados obtidos no questionário. Foram considerados aderentes ao tratamento os pacientes que tomaram pelo menos $80 \%$ da quantidade de comprimidos prescritos nos últimos sete dias antes da entrevista. Resultados: A prevalência de adesão encontrada foi de 82,8\% (IC95\%=78,8 - 86,5). As variáveis que apresentaram associação com a adesão foram: idade, número de comprimidos, comportamento nos fins de semana e/ou eventos sociais, frequência às consultas, uso de drogas ilícitas, comportamento diante do esquecimento de uma dose e consumo de bebidas alcoólicas. As adesão foram: sexo, modo de aquisição do vírus, tempo de diagnóstico, tabagismo e comportamento diante dos exames laboratoriais. Conclusões: O consumo de bebidas alcoólicas parece influenciar negativamente na adesão ao tratamento; Pacientes em uso de um maior número de comprimidos ao dia apresentam menor prevalência de adesão á HAART; Mulheres parecem ser mais aderentes ao tratamento em relação aos homens; Não há associação entre sexo, modo de aquisição do vírus e tempo de diagnóstico e adesão aos ARV.

\section{LAUDO RADIOLÓGICO: COMPARAÇÃO DA EFICIÊNCIA NA TRANSMISSÃO DE INFORMAÇÕES ENTRE O TEXTO LIVRE E O LAUDO ESTRUTURADO}

\section{Flávio Barbosa}

Orientador: Prof. Dr. Valdair Francisco Muglia

Dissertação de Mestrado apresentada em 09/03/2009

Geralmente, o resultado de um exame diagnóstico é transmitido através de um relatório, elaborado pelo médico que o executa para o médico solicitante. A elaboração livre, sem qualquer regra ou padrão, do laudo pelo médico executante, é rotineira, porém gera reclamações por parte dos médicos solicitantes, frequentemente relacionadas à terminologia e ao conteúdo, que nem sempre é completo, preciso e conclusivo. O objetivo desse trabalho foi estudar a viabilidade de implantação de um laudo estruturado, em um hospital universitário e, se isso resulta em melhoria na transmissão de informações. O laudo escolhido foi o laudo de ultra-sonografia de tireóide. As informações e terminologias foram padronizadas, utilizando um software de laudo estruturado, construído a partir de informações dos médicos solicitantes e executantes, em ambiente de internet. A ferramenta utilizada para construção do software foi o Borland Developer Studio 2006 (Zarko, 2009), sob plataforma Microsoft.Net (Microsoft, 2009). Durante dois meses, o tempo para elaboração do laudo textual (livre) foi medido e gravado. O mesmo foi feito com o laudo estruturado nos dois meses seguintes. Ambos os modelos de laudo foram avaliados, após o período de utilização, através de questionários específicos, aplicados aos médicos solicitantes e executantes para avaliar a mudança do textual para o estruturado. Cento e cinquenta e sete (157) exames com tempo médio igual a 7,1 $\pm 4,5$ minutos foram elaborados sob a forma livre. Com o uso do laudo estruturado, 100 exames com tempo médio igual a 5,4 \pm 3,6 minutos. A diferença do tempo total (laudos com presença de nódulos e sem presença de nódulos) e do tempo com nódulos entre os laudos gerados estruturado e os por texto livre foi significativa após a análise estatística ( -valor < 0,01). No entanto, quando se considera apenas os laudos sem nódulos,a diferença não é significativa médicos solicitantes $(n=10)$, a maioria $(8 / 10=80 \%)$ preferiu o laudo estruturado. Todos concordaram que houve padronização da descrição e $70 \%$, que houve melhora na transmissão de informação. Dos médicos executantes $(\mathrm{n}=21), 16(76,2 \%)$ também preferiram o laudo estruturado porque padronizou a descrição dos achados $(20 / 21=95,2 \%)$ e facilitou a emissão do laudo $(14 / 21=66,7 \%)$. Este trabalho concluiu que é viável a implantação de um laudo estruturado em um hospital universitário, melhorando a velocidade da elaboração do laudo e a transmissão das informações entre médico solicitante e executante. 


\title{
Farmacologia
}

\section{AVALIAÇÃO DA PARTICIPAÇÃO DO BDNF HIPOCAMPAL NO EFEITO ANTIDEPRESSIVO DA IMIPRAMINA EM RATOS SUBMETIDOS AOS MODELOS DO NADO FORÇADO E DO DESAMPARO APRENDIDO}

\author{
Caroline Biojone
}

Orientador: Prof. Dr. Francisco Silveira Guimarães

Dissertação de Mestrado apresentada em 06/02/2009

Alterações nos níveis hipocampais de BDNF (brain derived neurotrophic factor ou fator neurotrófico derivado do encéfalo) têm sido implicadas na etiologia da depressão. A exposição a eventos estressantes é capaz de diminuir enquanto que o tratamento prolongado com drogas antidepressivas pode aumentar os níveis de BDNF no hipocampo. Entretanto, estudos investigando o efeito do estresse associado ao tratamento antidepressivo têm produzido resultados contraditórios. O objetivo do presente estudo foi investigar os níveis hipocampais de BDNF em animais tratados com imipramina e submetidos a diferentes modelos utilizados no estudo da depressão, o nado forçado (forced swimming test, FST) e o desamparo aprendido (learned helplessness, $\mathrm{LH})$. Ratos Wistar $(220 \mathrm{~g})$ receberam imipramina $(15 \mathrm{mg} / \mathrm{k} \mathrm{mg}$ ) ou veículo em três injeções i.p. (24, $19 \mathrm{e} 1 \mathrm{~h}$ antes do teste, tratamento curto) e foram submetidos ao FST. Um grupo independente recebeu imipramina na mesma dose diariamente durante 7 dias (tratamento prolongado) e foi submetido ao LH. Animais nãoestressados foram submetidos aos tratamentos farmacológicos correspondentes. Tanto o tratamento curto quanto o prolongado foram capazes de induzir efeito do tipo antidepressivo no FST e no LH, respectivamente. Entretanto, apenas o tratamento prolongado foi capaz de aumentar os níveis hipocampais de BDNF medidos por ELISA. Interessantemente, nos grupos de animais estressados (submetidos ao FST ou ao LH) nem o tratamento antidepressivo nem o estresse alteraram os níveis hipocampais de BDNF. Os resultados deste estudo indicam que o aumento nos níveis de BDNF produzido pelo tratamento antidepressivo desaparece em associação ao estresse. Dessa forma, sugere-se que o estresse e o tratamento antidepressivo interagem para modular a expressão de BDNF.

\section{ENVOLVIMENTO DO NÚCLEO MEDIAL DA AMÍGDALA NAS RESPOSTAS CARDIOVASCULARES À RESTRIÇÃO AGUDA EM RATOS}

\section{Eduardo Albino Trindade Fortaleza}

Orientador: Prof. Dr. Fernando Morgan de Aguiar Corrêa

Dissertação de Mestrado apresentada em 09/02/2009

O núcleo medial da amígdala (NMA) está envolvido no controle de uma variedade de processos fisiológicos e comportamentais, bem como na regulação do sistema nervoso autônomo. Dados da literatura indicam que o NMA modula respostas cardiovasculares e comportamentais associadas a estímulos estressantes. O estresse por restrição (ER) evoca alterações cardiovasculares caracterizadas por aumento da pressão arterial (PA) e um intenso aumento na frequência cardíaca (FC). No presente estudo, avaliamos o efeito da manipulação farmacológica no NMA nas respostas da PA e FC causadas pelo ER. A microinjeção bilateral de cloreto de cobalto $(1 \mathrm{mM} / 1 \mu \mathrm{L})$ inibidor sináptico não seletivo no NMA aumenta a resposta taquicárdica durante o estresse agudo, sem efeito significativo na resposta pressora. Este resultado sugere que sinapses no NMA têm um mecanismo inibitório no componente cardíaco durante o ER. A microinjeção local de atropina $(3 \mathrm{nmol} / 1 \mu \mathrm{L})$ antagonista muscarínico não seletivo, hemicolínio $(2 \mathrm{nmol} / 1 \mu \mathrm{L})$ inibidor da captação de colina e pirenzepina $(6 \mathrm{nmol} / 1 \mu \mathrm{L})$ e o antagonista muscarínico seletivo M1 causaram efeito similar ao cobalto, sugerindo que a neurotransmissão colinérgica local é mediada por receptores muscarínicos do subtipo M1, que exercem papel inibitório sobre o componente cardíaco da resposta cardiovascular ao ER. O pré-tratameto com 4-DAMP $(2 \mathrm{nmol} / 1 \mu \mathrm{L})$ antagonista muscariníco seletivo M3 não afetou as alterações cardiovasculares durante ER, reforçando a idéia que o papel inibitório no MNA é mediado por receptores M1. Além disso, o pré-tratamento com neostigmina ( $1 \mathrm{nmol} / 1 \mu \mathrm{L})$ um inibidor da colinesterase não alterou a resposta cardiovasculare ao ER. Portanto, estes resultados sugerem que o NMA tem um papel inibitório no aumento da FC causado pelo ER. 


\title{
CONSEQUÊNCIAS DA LESÃO POR CATÉTER-BALÃO SOBRE O RELAXAMENTO MEDIADO POR

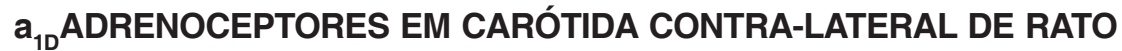

\author{
Larissa Pernomian
}

Orientadora: $\operatorname{Prof}^{\mathrm{a}}$. Dr ${ }^{\mathrm{a}}$. Ana Maria de Oliveira

Dissertação de Mestrado apresentada em 09/02/2009

A angioplastia por catéter-balão é um procedimento utilizado para restaurar o fluxo sanguíneo em vasos acometidos por doenças obstrutivas. Em carótida de rato, a passagem do catéter-balão pela luz arterial produz um estresse mecânico que altera a reatividade a agentes vasoconstrictores e a inervação sensorial na artéria contra-lateral à lesão, sugerindo a ocorrência de uma resposta neurocompensatória nesse leito. Esse processo caracteriza-se por um aumento na resposta contrátil à fenilefrina, quatro dias após a lesão vascular, envolvendo a participação do endotélio e de prostanóides derivados da ciclooxigenase-2, o comprometimento na formação de óxido nítrico endotelial e o aumento na produção de ânion superóxido locais. Recentemente, a existência de $\mathrm{a}_{1 \mathrm{D}}$ adrenoceptores de relaxamento foi demonstrada funcionalmente, sugerindo a participação desses receptores na modulação da vasoconstricção adrenérgica. Evidências apontam um prejuízo no relaxamento mediado por a1D-adrenoceptores em carótida de ratos hiperhomocisteinêmicos, subjacente ao estresse oxidativo estabelecido nessa condição. Com base nisso, a hipótese do presente estudo é que a lesão por catéterbalão prejudica o relaxamento mediado por a1D-adrenoceptores em carótida contra-lateral de rato, quatro dias após a lesão, o que poderia estar contribuindo com a hiperreatividade contrátil à fenilefrina observada nesse leito durante esse período. Assim, o projeto teve por objetivo estudar as consequências da lesão por catéter-balão sobre o relaxamento mediado por a1D-adrenoceptores em carótida contra-lateral de rato, quatro dias após a lesão. A resposta de relaxamento adrenérgico foi estudada pela construção de curvas concentração-efeito cumulativas para fenilefrina $\left(10^{-15}\right.$ a $\left.10^{-10} \mathrm{~mol} / \mathrm{L}\right)$, sobre a pré-contração com prostaglandina F2a $\left(3 \times 10^{-5} \mathrm{~mol} / \mathrm{L}\right)$, em anéis de carótida. Em paralelo, procedeu-se com a caracterização funcional dos receptores e mediadores celulares do relaxamento induzido por fenilefrina em carótida de rato, bem como com o estudo da participação do ânion superóxido nessa resposta, sua principal fonte na artéria contra-lateral e as consequências da lesão vascular sobre a produção local de ânion superóxido por citometria de fluxo. Os resultados mostram que o relaxamento induzido por fenilefrina, caracterizado como endotélio-dependente e mediado por a1Dadrenoceptores, óxido nítrico endotelial e monofosfato de guanosina cíclico, está abolido em carótida contra-lateral de rato, quatro dias após a lesão. A inibição da enzima ciclooxigenase-2, ou a remoção do ânion superóxido, normalizaram as respostas à fenilefrina em carótida contra-lateral. Em paralelo, foi encontrado que a lesão por catéter-balão aumenta a produção de ânion superóxido no endotélio de artérias contra-laterais, nas quais a fonte do radical é a ciclooxigenase- 2 . Esse achados permitem concluir que a lesão por catéter-balão leva à perda do relaxamento mediado por a1D-adrenoceptores em carótida contra-lateral de rato, quatro dias após a lesão, contribuindo com o aumento da resposta contrátil à fenilefrina nesse leito. Os mecanismos subjacentes à abolição dessa resposta na artéria contra-lateral envolvem a participação do ânion superóxido, derivado do metabolismo local da ciclooxigenase-2.

\section{PAPEL DA caspase-1 NA GÊNESE DA RESPOSTA INFLAMATÓRIA DURANTE A SEPSE GRAVE EXPERIMENTAL}

\author{
Fabiane Sônego \\ Orientador: Prof. Dr. Fernando de Queiróz Cunha \\ Dissertação de Mestrado apresentada em 10/03/2009
}

Sepse é uma resposta inflamatória sistêmica que decorre da inabilidade do hospedeiro em controlar uma infecção local. De fato, trabalhos prévios de nosso laboratório demonstram que ocorre um prejuízo na migração de neutrófilos durante a sepse grave, que é associado ao aumento das concentrações séricas de citocinas, bacteremia e aumento da mortalidade dos animais. A participação dos receptores Toll-like (TLRs) foi recentemente descrita neste processo de falência da migração de neutrófilos na sepse grave. A caspase-1 é uma enzima que parece ser importante na ativação da via de sinalização dos TLRs além de ter um papel essencial na ativação das citocinas inflamatórias IL-1b, IL-18 e IL-33. Neste trabalho, nós avaliamos a participação da caspase-1 na gênese da resposta inflamatória na sepse grave. Observamos que os animais deficientes para caspase-1 apresentaram maior resistência à sepse induzida por CLP (cecal ligation and puncture). No entanto, animais deficientes para IL-18 ou ST2 (receptor da IL-33) não apresentaram redução na mortalidade após indução da sepse. O tratamento com antagonista do receptor da IL-1 foi também incapaz de alterar a curva de sobrevida de animais selvagens submetidos à sepse grave. Estes dados indicam que a redução nos níveis destas citocinas 
não é relevante para a redução da mortalidade observada nos animais deficientes para caspase-1 submetidos à sepse. A redução na mortalidade dos animais deficientes para caspase-1 foi associada à reduzida concentração sistêmica de TNFa e IL-6. Apesar das concentrações locais de citocinas e quimiocinas apresentarem-se inalteradas, os animais deficientes para caspase-1 submetidos à sepse grave apresentaram um aumento na migração de neutrófilos para a cavidade peritoneal, que foi favorecida pelo aumento no número de rolamentos e adesões dos leucócitos nestes animais. Como consequência, observamos uma redução no crescimento bacteriano no exudato peritoneal e no sangue destes animais, embora os neutrófilos dos animais deficientes para caspase-1 ou selvagens tenham apresentado capacidade microbicida e viabilidade celular semelhantes. Assim, na ausência da caspase-1, há maior migração de neutrófilos para a cavidade peritoneal, que culmina na redução da mortalidade devido ao eficiente controle da infecção.

\title{
PAPEL DOS RECEPTORES DO TIPO 5-HT2C DO NÚCLEO BASOLATERAL DO COMPLEXO AMIGDALÓIDE DE RATOS NA MODULAÇÃO DE COMPORTAMENTOS DEFENSIVOS ASSOCIADOS À ANSIEDADE E AO PÂNICO
}

\author{
Maria Adrielle Vicente \\ Orientador: Prof.Dr. Hélio Zangrossi Júnior \\ Dissertação de Mestrado apresentada em 27/03/2009
}

Evidências na literatura apontam o núcleo basolateral do complexo amigdalóide como uma estrutura importante na elaboração e controle das respostas defensivas. O sistema serotonérgico é um dos tantos sistemas de neurotransmissão que estão envolvidos nessas respostas. Dentre os diferentes subtipos de receptores serotonérgicos existentes, os do tipo $5-\mathrm{HT}_{2 \mathrm{C}}$ é um dos mais estudados com relação à mediação dos processos de ansiedade. A estimulação de receptores 5-HT $2 \mathrm{C}$ tem efeito do tipo ansiogênico em diferentes modelos animais de ansiedade. Porém, não se conhece ainda a real participação desses receptores localizados no núcleo basolateral do complexo amigdalóide sobre as respostas de esquiva e fuga geradas no labirinto em T elevado relacionas, respectivamente, com ansiedade generalizada e pânico. Assim, o presente trabalho teve por objetivo verificar o papel dos receptores serotonérgicos do tipo 5-HT ${ }_{2 \mathrm{C}}$ do núcleo basolateral do complexo amigdalóide na modulação das respostas defensivas associadas à ansiedade generalizada e ao pânico. Foram realizadas injeções bilaterais intra-núcleo basolateral do agonista endógeno serotonina, do agonista preferencial de receptores 5- $\mathrm{HT}_{2 \mathrm{C}}$ MK-212 ou do antagonista seletivo desses receptores SB242084 em ratos submetidos ao teste do labirinto em T elevado e teste de transição claro-escuro. Os resultados mostram que a administração do agonista endógeno serotonina e do agonista de receptores do tipo 5- $\mathrm{HT}_{2 \mathrm{C}} \mathrm{MK}-212$ promove uma facilitação na aquisição da esquiva inibitória em ratos testados no labirinto em T elevado. A administração dos agonistas também diminui o tempo gasto pelos animais no compartimento claro da caixa claro-escuro, também sugerindo um efeito do tipo ansiogênico. Por outro lado, a administração local do antagonista dos receptores $5-\mathrm{HT}_{2 \mathrm{C}}$ SB-242084 prejudica tal resposta. Esse mesmo tratamento não altera a resposta no teste de transição claro-escuro. A administração prévia de SB-242084 é capaz de bloquear o efeito ansiogênico promovido pela serotonina. Nem a ativação nem o bloqueio desses receptores exerceu efeito sobre a resposta de fuga. Em suma, nossos resultados sugerem que os receptores 5-HT2C do núcleo basolateral do complexo amigdalóide têm papel regulatório sobre a resposta de esquiva inibitória, mas não sobre a resposta de fuga gerada no labirinto em T elevado.

\section{Fisiologia}

\section{PARTICIPAÇÃO DOS RECEPTORES IONOTRÓPICOS GLUTAMATÉRGICOS DO NÚCLEO MAGNO DA RAFE NA HIPOTERMIA E HIPERVENTILAÇÃO INDUZIDA POR HIPÓXIA E HIPERCAPINIA}

\section{Tatiane Borodinas Nucci}

Orientador: Prof. Dr. José Antunes Rodrigues

Dissertação de Mestrado apresentada em 06/03/2009

O núcleo magno da rafe (NMR) é um dos grupos celulares do tronco encefálico descrito como estando envolvido nas respostas fisiológicas à hipóxia e à hipercapnia. Deste modo o objetivo do presente trabalho foi estudar a participação dos receptores ionotrópicos glutamatérgicos no NMR nas respostas ventilatórias e termorregulatórias à hipóxia e à 
hipercapnia. Medidas de Ventilação pulmonar (VE) e da temperatura corporal (Tc) de ratos Wistar machos foram feitas antes e após a microinjeção de Ácido Kinurênico (KY, antagonista dos receptores ionotrópicos glutamatérgicos, 10 hmol/ $0,1 \mathrm{~mL})$ no $\mathrm{NMR}$, seguidas de 60 minutos de exposição à hipóxia $\left(7 \% \mathrm{O}_{2}, 21 \% \mathrm{~N}_{2}\right)$ ou à hipercapnia $\left(7 \% \mathrm{CO}_{2}, 21 \% \mathrm{O}_{2}\right.$ and $\mathrm{N}_{2}$ balance). A microinjeção de veículo ou KY não afetou a VE ou a Tc dos animais em condições de normóxia. A exposição à hipercapnia promoveu um aumento da ventilação pulmonar em todos os grupos, entretanto a resposta ventilatória à hipercapnia no grupo que recebeu a microinjeção de KY intra-NMR foi significativamente aumentada comparada com o grupo veículo. Essa diferença foi decorrente a um aumento no Volume Corrente (VT) desses animais. A hipóxia também causou um aumento da ventilação pulmonar, contudo a resposta ventilatória à hipóxia foi atenuada no grupo tratado com KY intra-NMR. A hipotermia induzida por hipóxia ou por hipercapnia não foi afetada pelo tratamento com KY intra-NMR. Os dados do presente estudo sugerem que o glutamato, atuando através dos receptores glutamatérgicos no NMR, exerce uma modulação inibitória na hiperpnéia induzida pela hipercapnia e uma modulação excitatória na hiperventilação induzida pela hipóxia.

\section{DEPRESSÃO PÓS ESTIMULATÓRIA DOS BARORRECEPTORES AÓRTICOS EM RATOS E CAMUNDON- GOS: INFLUÊNCIA DOS DERIVADOS DA CICLOOXIGENASE E DE ESPÉCIES REATIVAS DE OXIGÊNIO}

\section{Valter Joviniano de Santana Filho}

Orientador: Prof. Dr. Rubens Fazan Junior

Tese de Doutorado apresentada em 09/03/2009

A atividade dos barorreceptores é transitoriamente inibida após breves períodos de aumento na pressão arterial ou curtos períodos de estimulação elétrica das aferências barorreceptoras. Esse fenômeno é denominado "depressão pósestimulação (DPE)". Fatores inibitórios, com espécies reativas de oxigênio, e excitatórios, como os metabólitos da ciclooxigenase $(\mathrm{COX})$, podem ser liberados das terminações barorreceptoras durante sua ativação, podendo modular a DPE. Avaliamos a hipótese que o bloqueio da produção de peróxido de hidrogênio $\left(\mathrm{H}_{2} \mathrm{O}_{2}\right)$ pela administração de PEG-catalase abole a DPE enquanto que o bloqueio da produção de metabólitos da COX com a indometacina retarda a recuperação da DPE após a ativação dos barorreceptores com a oclusão da aorta abdominal ou estimulação antidrômica das terminações barorreceptoras in vivo. A atividade aferente dos barorreceptores foi avaliada pela atividade do nervo depressor aórtico em ratos Wistar anestesiados com tiopental sódico $(40 \mathrm{mg} / \mathrm{kg}$, ip) antes e após curtos períodos (10 ou 3 minutos) de coarctação da aorta abdominal ou estimulação antidrômica do nervo depressor aórtico (5 V, $2 \mathrm{~ms}, 20 \mathrm{~Hz}$ por $10 \mathrm{~s})$. O protocolo de estimulação também foi realizado em camundongos c57/Bl. Em ambos os protocolos, a porção cranial do nervo depressor aórtico foi seccionada antes de se iniciar o protocolo para evitar alterações reflexas na pressão arterial. Os protocolos foram realizados antes e após a administração do inibidor da COX, indometacina ( $5 \mathrm{mg} / \mathrm{kg}$, iv, somente em ratos), quelante de $\mathrm{H}_{2} \mathrm{O}_{2}$ PEG-catalase (104 U/kg, IV, em ratos e camundongos) ou salina (0.1 mL/100 g, iv). Não foram observadas diferenças no padrão de resposta da atividade do nervo depressor aórtico entre a coarctação de 10 ou 3 minutos. Foi observada uma redução na atividade dos barorreceptores para $60 \pm 10 \%$ do basal, imediatamente (5s) após o retorno da pressão arterial a valores normais após a coarctação da aorta abdominal. Houve uma recuperação da atividade

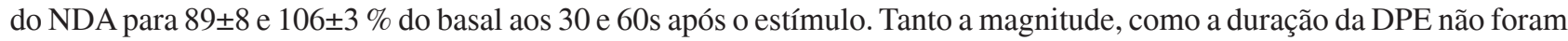
alteradas após a administração de salina. A DPE foi significantemente potencializada pela a administração de indometacina ( $77 \pm 6$ e $90 \pm 5 \%$ do basal 30 e 60 s após a coarctação da aorta), mas foi abolida pela administração de PEG-catalase (97士3 e $108 \pm 3 \%$ do basal 5 e 60s após a coarctação da aorta). Quando a indometacina foi administrada junto com a PEG-catalase,

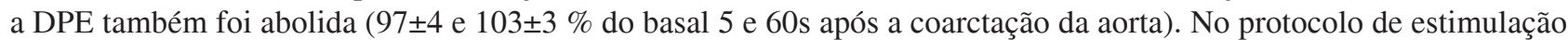
elétrica, foi observada uma grande queda na atividade dos barorreceptores após sua estimulação, chegando a valores de $19 \pm 2 \%$ da atividade basal, imediatamente (5s) após a estimulação elétrica do nervo depressor aórtico, não sendo associ-

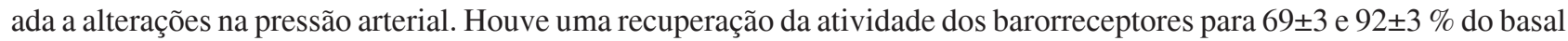
aos 60 e 120s após o estímulo. Semelhante ao protocolo anterior, a DPE não foi alterada pela administração de salina. A DPE foi significantemente prolongada pela indometacina ( $43 \pm 6$ e $49 \pm 8 \%$ do basal aos 60 e 120 s após a estimulação dos

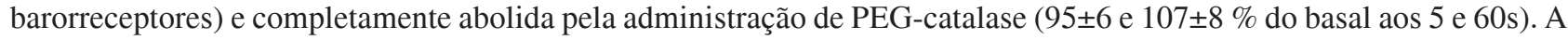
administração conjunta de indometacina e PEG-catalse promoveu uma redução da atividade dos barorreceptores, após sua ativação, de intensidade menor quando comparado ao controle (34+4 \% do basal 5s após sua estimulação), porém não houve uma recuperação da atividade dos barorreceptores no período estudado, permanecendo em patamar inferior até o final do experimento ( $60 \pm 7 \%$ do basal 300 s após sua estimulação). Os experimentos em camundongos tiveram o mesmo comportamento dos realizados com ratos. 


\title{
MODULAÇÃO DA PRESSÃO ARTERIAL E FREQUENCIA CARDÍACA PELA VIA OXIDO-NIITRICO GUANOSINA MONOSFATO CÍCLICO DA MEDULA ESPINHAL
}

\author{
João Paulo Jacob Sabino \\ Orientador: Prof. Dr. Hélio Cesar Salgado \\ Dissertação de Mestrado apresentada em 13/03/2009
}

A ativação da via óxido nítrico/guanosina monofosfato cíclico (NO/GMPc) em neurônios pré-ganglionares simpáticos (NPGS) ainda não está bem caracterizada. Assim, o objetivo deste estudo foi examinar os efeitos das alterações da via NO/GMPc na medula espinhal sobre as respostas de pressão arterial média (PAM) e frequência cardíaca (FC). Métodos: Foram utilizados ratos (n=6-7) submetidos à canulação intratecal e da artéria femoral. Foram registradas a PAM $(\mathrm{mmHg})$ e FC (bpm) basais durante 25 min, e durante 10 ou 30 min após a administração das drogas. As drogas foram administradas intratecalmente. Resultados: O bloqueio da NO sintase com Nv-Nitro-L-arginine methyl ester hydrochloride (L-NAME) aumentou a PAM $(10 \pm 1 \mathrm{mmHg})$ e não alterou a FC ( $7 \pm 12 \mathrm{bpm})$, enquanto que o isômero inativo Nv-Nitro-Darginine methyl ester hydrochloride (D-NAME) não alterou a PAM $(0 \pm 1 \mathrm{mmHg})$ e nem a FC $(5 \pm 5 \mathrm{bpm})$. O inibidor da guanilato ciclase solúvel $1 \mathrm{H}-[1,2,4]$ oxadiazolo[4,3-a]quinoxalin-1-one (ODQ) não alterou a PAM $(0 \pm 2 \mathrm{mmHg})$ e nem a FC ( $0 \pm 6$ bpm). O veículo dimetilsulfóxido (DMSO) não alterou a PAM $(-3 \pm 4 \mathrm{mmHg})$ e nem a FC (-1 $1 \pm 6 \mathrm{bpm})$. $\mathrm{O}$ antagonista do receptor N-Metil-D-Aspartato (NMDA), ácido aminofosfonopentanoico (AP5), não alterou a PAM (0 $\pm 2 \mathrm{mmHg}$ ), mas reduziu a FC (-17 \pm 7 bpm). A administração intratecal do fluido cerebroespinhal artificial (veículo) não alterou a PAM $(2 \pm 1$ $\mathrm{mmHg})$ e nem a FC (4 $\pm 4 \mathrm{bpm})$. A administração de L-NAME+AP5 não afetou o aumento da PAM $(8 \pm 1 \mathrm{mmHg})$ promovido pelo L-NAME. O precursor da síntese de NO, (S)-2-Amino-5-guanidinopentanoic acid; S(+)-2-Amino-5-[(aminoiminomethyl) amino]pentanoic acid (L-arginina), promoveu redução da PAM $(-5 \pm 2 \mathrm{mmHg})$ e FC (-29 $\pm 9 \mathrm{bpm})$, e seu isômero inativo, (R)-

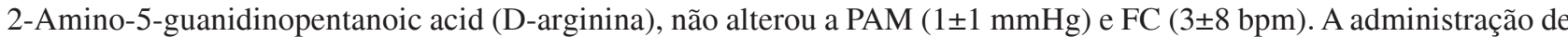
ODQ+L-arginina aboliu a queda na PAM $(3 \pm 2 \mathrm{mmHg})$ promovida pela $\mathrm{L}$-arginina, enquanto que sobre a FC houve uma redução parcial da bradicardia promovida pela L-ARGININA $(-14 \pm 4 \mathrm{bpm})$. Conclusão: Os resultados obtidos em ratos acordados indicam que o NO atua como neuromodulador inibitório tônico sobre os NPGS, cuja ação parece não envolver receptores NMDA e nem depender do GMPc. Todavia, a resposta à injeção de L-arginina foi dependente de GMPc.

\section{MECANISMOS ENVOLVIDOS NA AÇÃO ANABÓLICA E ANTIATRÓFICA DO AGONISTA ADRENÉRGICO b2 NO METABOLISMO DE PROTEÍNAS EM MÚSCULOS ESQUELÉTICOS DE RATOS}

\author{
Dawit Albieiro Pinheiro Gonçalves \\ Orientador: Prof. Dr. Luiz Carlos Carvalho Navegantes \\ Dissertação de Mestrado apresentada em 27/03/2009
}

O tratamento crônico com agonistas adrenérgicos b2 (e.g., clembuterol) promove aumento da massa muscular e atenuação da atrofia em músculos esqueléticos de animais e humanos. Contudo, os mecanismos intracelulares envolvidos com estes efeitos ainda são pouco conhecidos. Portanto, o objetivo deste trabalho foi avaliar as alterações induzidas pelo tratamento de curto prazo com clembuterol (CB; $3 \mathrm{mg} / \mathrm{kg}$ massa corporal; 3 dias; s.c.) nas atividades e expressões de diferentes componentes proteolíticos e na velocidade de síntese protéica em músculos esqueléticos glicoliticos (extensor digitorum longus; EDL) e oxidativos (soleus) de ratos normais e desnervados (3 dias apos a secção do nervo isquiático). Em ratos normais, o agonista b2 não promoveu aumento de massa muscular, mas estimulou a velocidade de síntese protéica $(\sim 25 \%)$ e reduziu a degradação total de proteínas $(\sim 15 \%)$ em ambos os músculos estudados. O efeito antiproteolitico do CB em EDL foi resultante da inibição da atividade proteolítica do sistema Ub-proteassoma (47\%), enquanto que em soleus o CB induziu redução da via dependente de $\mathrm{Ca} 2+(41 \%)$ e aumento de $\sim 5 \mathrm{x}$ do conteúdo da calpastatina, sem alteração das calpainas. A desenervação motora reduziu a massa do músculo soleus e causou uma elevação de $~ 60 \%$ na degradação total de proteínas. Alem disso, promoveu um aumento do conteúdo de AMPc muscular ( 74\%), sugerindo aumento da sensibilidade adrenérgica. A atrofia muscular foi acompanhada pela hiperativação dos sistemas lisossomal $(\sim 110 \%)$ e dependente de Ubproteassoma ( 140\%) assim como pela maior expressão protéica ( 4 vezes) da atrogina-1. Todas essas alterações foram atenuadas ou completamente abolidas apos o tratamento com CB. Entretanto, o aumento da atividade das catepsinas B e L ( $50 \%)$ e do conteúdo da catepsina B ( 77\%) induzidos pela desenervação não foram reduzidos pelo agonista b2. Embora a sintese proteica muscular nao tenha sido alterada pela desnervacao, o CB estimulou esse processo $(\sim 42 \%)$ no soleus desnervado. Este efeito foi maior em músculos desnervados do que em inervados. O conteúdo de IGF-I muscular não foi alterado nem pela secção do nervo e nem pelo tratamento com CB. Nossos resultados 
mostram que o tratamento in vivo de curto prazo com CB resulta em estimulação da síntese protéica muscular e inibição dos diferentes sistemas proteolíticos que variam de acordo com o estado de inervação e com o tipo de músculo estudado. Em situações normais, o efeito antiproteolitico induzido pelo CB no EDL e mediado pela inibição do sistema Ub-proteassoma, enquanto que no soleus o agonista b2 aumenta a expressão da calpastatina e com isso reduz a atividade da via dependente de $\mathrm{Ca} 2+$. O principal mecanismo da atenuação da atrofia do músculo soleus induzida pelo CB envolve a redução do conteúdo da atrogina-1 e, consequentemente, a inibição atividade do sistema Ub-proteassoma, independentemente da produção local de IGF-I.

\title{
Genética
}

\section{REGULAÇÃO DA EXPRESSÃO GÊNICA PELO FOSFATO NO FUNGO FILAMENTOSO Neurospora crassa}

\author{
Diana Ester Gras \\ Orientador: Prof.Dr. Antonio Rossi Filho \\ Tese de Doutorado apresentada em 06/02/2009
}

A regulação da expressão gênica é vital para todos os organismos se adaptarem rapidamente às mudanças ambientais. Estes mecanismos adaptativos são altamente complexos e a maioria deles não está completamente esclarecida. O fosfato inorgânico (Pi), um nutriente essencial para todos os organismos, é requerido em importantes processos celulares como a biosíntese de ácidos nucléicos e a sinalização metabólica. O sistema de aquisição de Pi no fungo filamentoso Neurospora crassa inclui pelo menos quatro genes regulatórios: nuc-2, preg, pgov e nuc-1. Em condições limitantes de Pi, NUC-2, uma proteína com domínio de repetição de anquirina, inibe o funcionamento do complexo PREG-PGOV, ativando assim o fator de transcrição NUC-1 e a expressão de genes envolvidos na captação de fosfato, como fosfatases, fosfato permeases e nucleases. Visando entender a funcionalidade do gene $n u c-2$ na regulação da expressão gênica em resposta aos níveis de Pi exógeno, foram construídas duas bibliotecas de subtração de cDNA entre as linhagens selvagem St.L.74A e $n u c-2$ A de $N$. crassa, cultivadas em Pilimitante. Obtivemos 52 transcritos induzidos e 16 reprimidos pela proteína NUC2. A categorização funcional destas sequências revelou genes envolvidos em diversos processos celulares, como transporte, regulação transcricional, transdução de sinal, metabolismo, síntese protéica e desenvolvimento. Entre os genes modulados negativamente pela proteína NUC-2, foi identificado um gene que codifica a proteína MAK-2 (mitogenactivated protein kinase-2), envolvida em vias de sinalização intracelular. O papel funcional deste gene no onitoramento do Pi extracelular foi avaliado por microarranjos de oligonucleotídeos, comparando as linhagens selvagem e mutante mak2, cultivadas em baixa concentração de Pi. Foram identificados 4.214 genes regulados pela proteína MAK-2, dentre eles a ciclina codificada pelo gene preg. Além disto, genes regulados em função da concentração de Pi foram identificados, mostrando o envolvimento de 3.174 transcritos. Os resultados obtidos neste trabalho revelam novos aspectos moleculares envolvidos na adaptação à disponibilidade de Pi extracelular, sugerindo que o gene mak-2 constitui um novo componente da via de sinalização e monitoramento de fosfato em N. crassa.

\section{IMPACTO DA UTILIZAÇÃO DA SOMATOTROPINA BOVINA (bST) SOBRE A PRODUÇÃO DE LEITE E A AVALIAÇÃO GENÉTICA DE BOVINOS DA RAÇA HOLANDESA}

\author{
Marcelo Rodrigues \\ Orientadora: Prof ${ }^{\mathrm{a}}$. Dr ${ }^{\mathrm{a}}$. Cláudia Cristina Paro de Paz \\ Dissertação de Mestrado apresentada em 18/02/2009
}

O objetivo do presente trabalho foi estudar a influência do uso da somatotropina bovina (bST) sobre a produção de leite e a avaliação genética de bovinos da raça Holandesa. Para análise foram utilizados dados referentes a 474 touros e observações referentes a 3341 lactações de 1271 vacas, provenientes da Agropecuária Agrindus - S.A no estado de São Paulo no período de 1999 a 2003. Análise de variância (método dos quadrados mínimos) foi realizada pelo procedimento GLM do SAS® (2003), visando identificar o efeito da classe de aplicação do bST sobre a produção de leite aos 305 dias de lactação (PL305). Os valores genéticos preditos dos touros (PBV), componentes de variância e herdabilidade para a característica PL305 foram estimados utilizando-se um modelo animal a partir de duas análises; na primeira incluiu-se o efeito do bST como fixo e na segunda o referido efeito foi ignorado. Foram calculadas correlações de Spearman entre PBV 
dos touros para quatro conjuntos de touros avaliados: a) todos os touros; b) os melhores 20\%; c) os melhores $10 \%$ e d) os melhores 5\%. As médias da PL305 para as classes de bST foram 9175,11kg - sem bST, 9530,94kg - de 11 a 20 aplicações, $10150,57 \mathrm{~kg}$ - de 21 a 30 aplicações e $11089,89 \mathrm{Kg}$ - de 31 a 59 aplicações. As herdabilidades foram respectivamente de

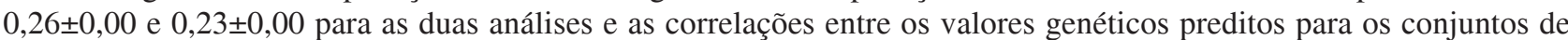
touros $a, b, c$ e $d$ foram, respectivamente, 0,9484, 0,9829, 0,9752 e 0,8974. A análise de variância demonstrou as médias de PL305 aumentaram significativamente $(\mathrm{P}<0,0001)$, com o aumento do número de aplicações do bST. Os coeficientes de herdabilidade, embora relativamente baixos, indicam possível ganho genético, por meio de seleção, para produção de leite. As altas correlações de Spearman entre os valores genéticos dos touros, considerando-se ou não o uso do bST no modelo, indicam que o uso desta tecnologia não interfere na classificação dos touros avaliados geneticamente.

\title{
DESENVOLVIMENTO DIFERENCIAL CASTA-ESPECÍFICO DAS PERNAS POSTERIORES DE Apis mellifera
}

\author{
Ana Durvalina Bomtorin \\ Orientadora: Prof ${ }^{a}$. Dr ${ }^{\mathrm{a}}$. Zilá Luz Paulino Simões \\ Dissertação de Mestrado apresentada em 11/03/2009
}

A diferenciação morfo-fisiológica entre rainhas e operárias de Apis mellifera decorre da alimentação recebida durante o desenvolvimento larval, que estimula o aumento da produção de Hormônio Juvenil nas larvas que originarão rainhas. Dentre as diversas diferenças morfológicas entre operárias e rainhas encontram-se estruturas especializadas para a coleta de pólen e própolis, localizadas na região da tíbia e do basitarso das pernas posteriores de operárias. A diferenciação das pernas tem início entre o quarto e o quinto estágio do desenvolvimento larval. Utilizando-se Microscopia Eletrônica de Varredura o presente trabalho relata a presença das cerdas formando as estruturas casta-específicas na fase de pupa de olho marrom. A partir de estudos de hibridação de microarrays de cDNA com amostras de RNA de A. mellifera de diversas fases do desenvolvimento larval, foram encontrados 91 genes com ortólogos conhecidos em Drosophila, diferencialmente expressos entre rainhas e operárias no período crítico da diferenciação de castas. Destes, cinco estão relacionados com o desenvolvimento de apêndices: ataxin-2 (atx-2), cryptocephal (crc), dachshund (dac), grunge (gug) e Retinoic and fat acid Binding Protein (RfaBP). O perfil destes genes, e ainda, ultrabithorax (ubx), distal-less (dll) e abdominal-A (abd-A) (estes por suas funções durante a diferenciação das pernas de insetos) foram analisados por RT-PCR em Tempo Real em pernas posteriores de operárias e rainhas desde o quarto estágio larval até o estágio de pupa de olho brano. Apenas $u b x$ e $a b d-A$ foram encontrados mais expressos em operárias ao final do desenvolvimento larval e início do desenvolvimento pupal. Estudos similares dos genes abd-A, dac, dll e ubx nos segmentos das pernas de pupas de olho branco indicam a tíbia como domínio de expressão de dac. Imunolocalizações utilizando um anticorpo contra um epitopo conservado entre Ubx e Abd-A, FP6.87, em pernas posteriores de pré-pupas de operárias e rainhas revelam a presença destas proteínas na tíbia apenas de operárias e diferencialmente localizadas no basitarso de operárias e rainhas. Os dados acima apresentados apontam Ubx, um gene Hox, como ponto-chave na regulação da formação das estruturas casta-específicas.

\section{ANÁLISE DA EXPRESSÃO GÊNICA EM CÉLULAS-TRONCO MESENQUIMAIS DE MEDULA ÓSSEA HUMANA DURANTE O COMPROMETIMENTO COM A LINHAGEM OSTEOGÊNICA}

\author{
Vanessa Fontana \\ Orientador: Prof.Dr. Geraldo Aleixo da Silva Passos Júnior \\ Dissertação de Mestrado apresentada em 17/03/2009
}

As células-tronco são definidas como células capazes de auto-renovação e diferenciação em células especializadas. Dentre as células-tronco adultas, as mesenquimais ocupam uma posição de destaque. São células multipotentes que podem originar células de origem mesodérmica, como osteoblastos, adipócitos e condrócitos. Além disso, vários estudos demonstraram que essas células também podem se diferenciar em células de origem extra-mesenquimal, como neurônios e hepatócitos, fenômeno este denominado plasticidade. Aspectos moleculares envolvidos com a plasticidade das célulastronco adultas, bem como durante o processo de comprometimento e diferenciação em células especializadas não estão completamente elucidados. Considera-se que as células-tronco expressam, embora em baixos níveis, uma gama diversa de genes relacionados aos diferentes destinos de diferenciação. Durante a diferenciação o repertório de genes expressos seria reduzido, acompanhado do aumento nos níveis de expressão de uma coleção menor de genes que orientariam a especialização celular. Para o presente estudo adotamos essa hipótese e elaboramos um sistema-modelo experimental no qual células-tronco mesenquimais de medula óssea humana foram induzidas in vitro à diferenciação em osteoblastos. As 
células-tronco mesenquimais foram obtidas de três doadores saudáveis de medula óssea e induzidas quimicamente à diferenciação em osteoblastos (meio a-MEM acrescido de dexametasona, ácido ascórbico e b-glicerofosfato) durante 24 h, 48 h, 7 dias e 21 dias. O RNA total foi extraído das culturas de células indiferenciadas (0h) e durante o processo de diferenciação ( 24 h, 48 h, 7 d e 21 d). Todo o processo de diferenciação foi monitorado com ensaios bioquímicos e por imunocitoquímica. Para avaliar a expressão gênica das célulastronco e durante o processo de diferenciação utilizamos a tecnologia dos cDNA microarrays. Os dados foram analisados com auxílio de programas de bioinformática especializados. Um banco público de dados de expressão gênica (GNF Symatlas) também foi consultado, o que nos auxiliou na interpretação dos dados. Sondas de cDNA fluorescentes (Cy3) oriundas das amostras de RNA foram hibridizadas com os cDNA microarrays (4.500 sequências alvo). Um pool de cDNAs irrelevantes marcados com Cy5 foi usada como referência na hibridização. A expressão gênica diferencial durante a diferenciação foi analisada pelo método SAM (significance analysis of microarrays) (FDR < 5\%). Os genes diferencialmente expressos foram classificados segundo sua representação tecidual de acordo com os valores de expressão obtidos do banco de dados GNF Symatlas. Além disso, foi avaliada por RT-PCR semiquantitativa, a expressão de genes relacionados à osteogênese (ALPL, osteocalcina, COL1A1, RUNX2 e osteopontina), e um marcador de adipócitos, PPARG. Observamos que as células-tronco mesenquimais no seu estado "tronco" expressam, em níveis similares, genes característicos das linhagens osteo e adipocítica. Entretanto, ao longo do comprometimento com a linhagem osteoblástica o número de genes modulados (reprimidos e induzidos) é crescente. Revelamos que nas fases iniciais da diferenciação osteoblástica in vitro os genes que representam células-tronco adultas foram reprimidos. Entretanto, com o avanço do comprometimento com a linhagem osteoblástica observamos que certos genes foram induzidos como, por exemplo, BMP1, SMAD7, IGFBP4, ITGA5, FN1, BGN, CDH8, GDF10 e SCARB2, todos relacionados à osteogênese. Nossos resultados são importantes para um melhor entendimento das bases genético-moleculares associadas ao potencial "plástico" e de diferenciação das células-tronco mesenquimais.

\title{
DIVERSIDADE GENÉTICA, SISTEMA REPRODUTIVO E FLUXO DE PÓLEN EM DUAS POPULAÇÕES DE Tabebuia roseo-alba (RIDL.) SAND.: IMPLICAÇÕES PARA A CONSERVAÇÃO
}

\author{
Juliana Massimino Feres \\ Orientadora: Prof ${ }^{a}$. Dr ${ }^{\mathrm{a}}$. Ana Lilia Alzate Marin \\ Dissertação de Mestrado apresentada em 20/03/2009
}

Tabebuia roseo-alba (Ridl.) Sand. (ipê branco) é uma árvore semidecídua que floresce abundantemente entre os meses de Agosto e Setembro. Valiosa pela qualidade de sua madeira, bem como por sua capacidade de ornamentação, esta espécie tem sido largamente utilizada em reflorestamentos e arborização urbana. A fragmentação florestal reduz o tamanho da população reprodutiva, a densidade populacional e pode isolar populações e indivíduos em campos e pastagens. Dessa forma, entender seus efeitos é fundamental para providenciar recomendações para conservação in situ e ex situ de espécies florestais. Assim, os objetivos desse trabalho foram: transferir, padronizar e caracterizar marcadores moleculares microssatélites previamente desenvolvidos em Tabebuia aurea para Tabebuia roseo-alba; avaliar a diversidade e divergência genética, o sistema reprodutivo e o fluxo de pólen em duas populações de Tabebuia roseo-alba submetidas a diferentes condições de preservação localizadas em área urbana no município de Ribeirão Preto- SP e ambiente natural em Selvíria-MS. Para isso, sementes de polinização aberta derivadas de árvores matrizes procedentes das duas populações em estudo foram coletadas. Todas as amostras tiveram seu DNA extraído e amplificado com oito pares de microssatélites heterólogos. As análises mostraram que todos os locos avaliados apresentaram herança mendeliana simples e segregam independentes, sendo, portanto, adequados para estudos de sistema de cruzamento, estrutura genética de populações e análise de paternidade. Também foi constatado que as duas populações têm elevada diversidade genética (He variando de 0,743 a 0,835) sendo as amostras de Selvíria mais diversas. Os níveis de divergência genética entre as populações foram altos e com tendência a aumentar quando comparadas as gerações de progênies. A análise do sistema de cruzamento, permitiu afirmar que as populações estudadas são mistas ( $m t$ Ribeirão Preto $=0,840$ e $m t$ Selvíria $=0,963$ ) com maior probabilidade de aumento na autofecundação nas árvores isoladas da população urbana. Significantes desvios do cruzamento aleatório foram observados através do cruzamento entre parentes e cruzamentos correlacionados entre e dentro de frutos, indicando endogamia nas populações. O número efetivo de doadores de pólen foi muito baixo para um mesmo fruto (1,21 em Ribeirão Preto e 1,50 em Selvíria) e mais alto entre frutos de uma mesma árvore (8,20 em Ribeirão Preto e 9,8 em Selvíria). A distância média do fluxo de pólen acessada pela análise TWOGENER foi baixa nas duas populações tanto para o modelo normal (35,4m em Ribeirão Preto e 57,3m em Selvíria) quanto para o exponencial (39,9m em Ribeirão Preto e 64,6m em Selvíria). Como o conhecimento da endogamia, cruzamentos correlacionados, autofecundação e estrutura genética espacial são fatores chave na tomada de decisões para a coleta de sementes e o plantio das mudas, estes resultados podem auxiliar programas de restauração florestal e conservação da espécie. 


\title{
AUXÍLIO AO DIAGNÓSTICO DE ARTRITE REUMATÓIDE ATRAVÉS DE TÉCNICAS DE INTELIGÊNCIA ARTIFICIAL
}

\author{
Gabriela Felix Persinoti \\ Orientadora: Prof ${ }^{\mathrm{a}}$. Dr ${ }^{\mathrm{a}}$. Silvana Giuliatti \\ Dissertação de Mestrado apresentada em 25/03/2009
}

Artrite Reumatóide (AR) é uma doença auto-imune, crônica e inflamatória cujas manifestações são notadas, principalmente, nas articulações. Um ponto de extrema importância nesta doença é a necessidade de diagnostico e início do tratamento dos pacientes o mais rápido possível, para que os danos às articulações e erosões ósseas sejam evitados, pois estes danos ocorrem no início da doença e são, muitas vezes, irreversíveis. O presente projeto teve como objetivo a construção de um sistema computacional via Web para o auxílio ao diagnóstico de pacientes portadores de artrite reumatóide, através da utilização de técnicas de inteligência artificial, como Redes Neurais Artificiais, Arvores de Decisão e Algoritmos Genéticos, e o sistema gerenciador de conteúdos Drupal. O objetivo do sistema é proporcionar um ambiente estruturado, no qual as informações clínicas e de expressão gênica de pacientes portadores de AR são cadastradas e categorizadas, para que, a partir destas informações, os algoritmos de aprendizado de máquinas possam ser treinados para selecionar características clínicas e genes relevantes para a predição da resposta dos pacientes ao tratamento com Drogas AntiReumáticas Modificadoras da Doença (DMARDs). Após o treinamento, os modelos gerados podem ser utilizados para a predição da resposta à DMARDs de novos pacientes. O sistema visa selecionar possíveis características que permitam identificar precocemente os pacientes que irão evoluir de forma mais agressiva e, assim, fornecer uma nova ferramenta para que os médicos possam indicar o melhor tratamento possível para cada paciente individualmente. O Sistema desenvolvido foi denominado ARIA e está disponível através do endereço http://gbi.fmrp.usp.br/artrite. Apenas médicos e colaboradores do projeto têm permissão para acessá-lo. Estão disponíveis os seguintes conteúdos: Cadastro de Pacientes, Ferramenta de Seleção de Atributos e Ferramenta de Predição da Resposta dos Pacientes à DMARDs. Além disso, o sistema disponibiliza diversas possibilidades de visualização e interação com tais conteúdos. Estão cadastrados, até o momento, 126 pacientes, sendo que 106 deles são utilizados para o treinamento da ferramenta de seleção de atributos e vinte deles para os testes da ferramenta de predição da resposta à DMARDs.

\section{GENES CODIFICADORES DE PEPTÍDEOS RELACIONADOS À ECDISE E AO CONTROLE DE SÍNTESE DO HORMÔNIO JUVENIL E DE ECDISTERÓIDES EM Apis mellifera}

\author{
FernandaAndrade Silva Torres \\ Orientadora: Prof $^{a}$. Dr ${ }^{a}$. Zilá Luz Paulino Simões \\ Tese de Doutorado apresentada em 27/03/2009
}

As mudas larvais e a metamorfose tornam possível aos insetos mudar de forma durante o ciclo de vida. Assim, além de permitirem que se adaptem a mudanças ambientais, entrando por exemplo em dormência em diferentes estágios do desenvolvimento, também possibilitam polifenismo, sendo estes manifestações fenotípicas divergentes a partir de um mesmo genótipo. A progressão ordenada das mudas depende dos ecdisteróides (ECD) e do hormônio juvenl (HJ), produtos de glândulas endócrinas protorácicas e retrocerebrais, respectivamente, que, por sua vez, têm a sua atividade controlada por neuropeptídeos. Neste contexto, nosso objetivo principal foi caracterizar a estrutura e expressão dos genes alatostatina (Amel-AS), inibidor da síntese de HJ; bombixina (Amel-bomb), potencial estimulador da síntese de $20 \mathrm{E}$ (principal ecdisteróide dos insetos); eclosion hormone (Amel-EH) e ecdysistriggering hormone (Amel-ETH), promotores dos comportamentos pré-ecdise e ecdise; e peroxidase (Amel-PXD), que participa do processo de esclerotização da cutícula nova após o desprendimento da cutícula velha. Além disso, através de estudos de aplicações hormonais de HJ e 20E, ligadura abdominal e cultivo de tegumentos com 20E in vitro, comprovamos as ações destes hormônios sobre os genes estudados. A partir da sequência do genoma de A. mellifera (Honeybee Genome Sequencing Consortium, 2006) foi realizado o sequenciamento dos cDNAs referentes aos genes em estudo, com exceção de Amel-ETH, que já havia sido sequenciado e depositado no GenBank (NM_001142607). A estrutura e arquitetura dos genes foram caracterizadas, e com exceção de Amel-ETH e Amel-PXD, todos são formados por 2 exons e 1 intron. Os tamanhos das sequências de aminoácidos deduzidas variam de 73 aminoácidos para a bombixina até 678 aminoácidos para a peroxidase. Dos motivos e domínios característicos destes peptídeos foram localizados os motivos YSFGL e YHFGL, que classificam a alatostatina de A. mellifera como do tipo-A; os domínios: insulin/insulinlike growth factor/relaxin (pfamcl02453) na sequência da bombixina; eclosion hormone (pfam04736) na sequência de eclosion hormone; e animal peroxidase (pfam03098) na sequência da peroxidase. As taxas de transcrição dos genes aqui descritos foram analisados em cérebro, ovário e corpo 
gorduroso de operárias recém-nascidas. Transcritos de Amel-AS foram identificados principalmente no cérebro e menos intensamente nos ovários. Transcritos de Amel-EH foram localizados somente no cérebro. Transcritos de Amel-bomb e Amel- PXD foram encontrados em todos os tecidos, embora em níveis baixos no caso de Amelbomb. Transcritos de AmelETH não foram encontrados nesses tecidos. Analisamos então cDNAs de células Inka de larvas e encontramos transcritos de Amel-ETH. Os níveis de transcritos dos genes estudados são modulados durante a metamorfose. A presença de transcritos de Amel-AS está restrita a fase pupal, onde há baixos títulos de HJ. Transcritos de Amel-bomb são encontrados em estágios onde há altos títulos de 20E, próximos à pupação. Transcritos de Amel-EH, Amel-ETH e Amel-PXD são identificados nas fases em que os títulos de 20E estão em declínio. Com a finalidade de investigar se esses genes são regulados por hormônios, foram realizados experimentos de manipulação hormonal. HJ foi aplicado em larvas e pupas, 20E foi injetado em pupas e usado para cultivo de tegumentos in vitro. Também foi realizado o experimento de ligadura abdominal em pupas. Os resultados indicam que 20E estimula a transcrição de Amel-AS, e inibe a transcrição de Amelbomb. Um pulso de 20E e seu posterior declínio são necessários para a transcrição de Amel-EH, Amel-ETH e Amel-PXD. Já o HJ estimula a transcrição de Amel-ETH e inibe a de Amel-EH. Em conjunto os resultados mostram que as estruturas dos genes são conservadas de modo geral, se comparadas às mesmas sequências em outros insetos. Os perfis de expressão dos genes ao longo do desenvolvimento são compatíveis com os de outros insetos já descritos. Os genes estudados são modulados principalmente pelos títulos de 20E, e somente Amel-EH e Amel-ETH também pelos títulos de HJ. Estudos destes genes em abelhas devem contribuir para o conhecimento da metamorfose dos insetos sociais.

\title{
Ginecologia e Obstetrícia
}

\section{EFEITOS CLÍNICOS E METABÓLICOS DO IMPLANTE LIBERADOR DE ETONOGESTREL SOBRE O PUERPÉRIO DE MULHERES SADIAS}

\author{
Milena Bastos Brito \\ Orientadora: $\operatorname{Prof}^{\mathrm{a}}$. Dr ${ }^{\mathrm{a}}$. Carolina Sales Vieira Macedo \\ Dissertação de Mestrado apresentada em 23/03/2009
}

Os contraceptivos de progestagênios isolados, como o implante liberador de etonogestrel, representam uma opção para uso no puerpério. Classicamente, recomenda-se seu uso, a partir da sexta semana após o parto, mas sabe-se que para um grupo de mulheres de risco para curtos intervalos intergestacionais (com baixa adesão ou pouco acesso às orientações contraceptivas neste período), os mesmos podem ser prescritos no puerpério imediato. Porém, mais estudos são necessários para avaliar a segurança materna e neonatal/infantil do implante de etonogestrel (ETG), quando inserido no puerpério imediato. O objetivo do presente estudo foi avaliar dados de segurança materna (clínicos e metabólicos) e neonatal (clínicos) do uso do implante liberador de ETG no puerpério imediato, durante as primeiras 12 semanas pós-parto. Randomizamos 40 pacientes, entre 18-35 anos, no Ambulatório de Pré-Natal de Baixo Risco do HCFMRP-USP, para dois grupos: 20 para uso do implante liberador de ETG (grupo ETG), inserido 24-48 h pós-parto; e 20 para uso de 150 mg de acetato de medroxiprogesterona de depósito (AMP-D), a partir da $6^{\mathrm{a}}$ semana de puerpério (grupo de controle). Os parâmetros clínicos avaliados foram: pressão arterial (PA), peso materno e neonatal, índice de massa corpórea (IMC), circunferência abdominal (CA) e taxa de manutenção de lactação exclusiva até a $12^{\mathrm{a}}$ segunda semana de puerpério. Os parâmetros laboratoriais avaliados foram: marcadores hepáticos (lesão e colestase): fosfatase alcalina (FA), gama-GT, transaminase glutâmico-pirúvica (TGP), transaminase glutamínica oxalicética (TGO), bilirrubinas totais (BT), bilirrubina direta (BD), bilirrubina indireta (BI), albumina; marcadores inflamatórios: interleucina (IL)-6, fator de necrose tumoral alfa (TNF-a), proteína C reativa (PCR); lipidograma; hemograma e glicemia. As pacientes apresentavam características clínicas e laboratoriais basais semelhantes. Observou-se redução da PA, triglicérides, LDL-colesterol, PCR, FA e elevação do peso dos recém-nascidos, da hemoglobina, plaquetas (mais pronunciada no grupo ETG) glicemia, TGP, BT, BD (mais pronunciada no grupo ETG), BI, albumina e durante as primeiras 12 semanas, em ambos os grupos, sem diferença entre eles. No entanto, o peso, IMC e CA reduziram-se mais no grupo ETG do que no grupo de controle entre o basal e a 6 ${ }^{\mathrm{a}}$ semana após o parto (DETG: - 4,64 $\pm 2,71 \mathrm{Kg}$ vs. Dcontrole: $-2,60 \pm 2,45 \mathrm{Kg}, \mathrm{p}=0,017$; DETG: $-1,77 \pm 1,06 \mathrm{Kg} / \mathrm{m}^{2}$ vs. Dcontrole: $-0,97 \pm 0,95 \mathrm{Kg} / \mathrm{m}^{2}$, p=0,026; DETG: $-15,30 \pm 6,72 \mathrm{~cm} v s$. Dcontrole: $-9,05 \pm 5,84 \mathrm{~cm}, \mathrm{p}=0,003$; respectivamente); os níveis de leucócitos apresentaram um aumento entre seis e 12 semanas no grupo de controle (DETG: - $440 \pm 113$ céls/mL vs. Dcontrole: $+254 \pm 377$ céls/ $\mathrm{mL}, p=0,005)$, com declínio entre o período basal e 12 semanas, semelhante em ambos os grupos; o nível de IL-6, apesar de declinar em ambos os grupos, apresentou variação estatisticamente maior entre o basal e 12 semanas no grupo ETG 
(DETG: $-14,30 \pm 20,33 \mathrm{pg} / \mathrm{mL}$ vs. Dcontrole: $-6,09 \pm 7,23 \mathrm{pg} / \mathrm{mL}, \mathrm{p}=0,035$ ); os níveis de TNF-a elevaram-se apenas no grupo de controle, após seis semanas do uso de AMP-D (DETG: $-0,55 \pm 2,46 \mathrm{pg} / \mathrm{mL} v s$. Dcontrole: $+2,21 \pm 3,18 \mathrm{pg} / \mathrm{mL}$, p=0,001); os níveis de CT e HDL declinaram nos dois grupos com maior queda no grupo de controle, entre seis e 12 semanas pósparto (DETG: $-7,4 \pm 15,01 \mathrm{mg} / \mathrm{dL} v s$. Dcontrole: $-28,55 \pm 17,71 \mathrm{mg} / \mathrm{dL}, \mathrm{p}=0,001$; DETG: - 0,15 \pm 5,02mg/dL vs. Dcontrole: $12,45 \pm 7,32 \mathrm{mg} / \mathrm{dL}, \mathrm{p}<0,0001$; respectivamente); os valores da TGO reduziram mais no grupo de controle em relação ao grupo ETG na variação entre basal e 12 semanas pós-parto (ETG: - 0,40 \pm 9,36U/L vs. controle: - 6,05 $\pm 8,07 \mathrm{U} / \mathrm{L}, p=0,048$ ). Todos os valores estavam dentro dos limites de normalidade para a faixa etária estudada. As demais variáveis e a taxa de manutenção da lactação exclusiva não diferiram entre os grupos. Podemos concluir que a inserção do implante liberador de ETG no pós-parto imediato não foi associada a efeitos clínicos deletérios maternos ou neonatais, nem a alterações laboratoriais maternas significativas.

\title{
EXPRESSÃO DO GENE DA AROMATASE (CYP19A1) NAS CÉLULAS DA GRANULOSA MURAIS LUTEINIZADAS DE MULHERES COM ENDOMETRIOSE SUBMETIDAS A TÉCNICAS DE REPRODUÇÃO ASSISTIDA
}

\author{
Lauriane Giselle de Abreu
}

Orientador: Prof. Dr. Marcos Felipe Silva de Sá

Tese de Doutorado apresentada em 26/03/2009

Introdução: Até $60 \%$ das mulheres com endometriose apresentam como sintoma a infertilidade. Entretanto, os mecanismos envolvidos ainda permanecem não totalmente esclarecidos, especialmente quando não há distorção da anatomia pélvica. A etiologia multifatorial e comprometimento poligênico nesta doença têm sido amplamente aceitos. A aromatase é uma molécula das mais estudadas e há evidências de aumento da expressão do seu gene no endométrio eutópico e ectópico na endometriose. Esta enzima, codificada pelo gene CYP19A1, converte andrógenos a estrógenos e está presente normalmente nas células da granulosa, onde é fundamental para a produção intrafolicular de esteróides. Estudos in vitro por cultivo de células da granulosa, mostraram redução da atividade da aromatase em mulheres com endometriose. Devido à escassez de estudos que analisem a expressão do seu gene (CYP19A1) nessas células propusemos este trabalho, que tem por objetivo verificar a sua expressão por PCR em tempo real nas células da granulosa luteinizadas murais de mulheres com endometriose submetidas a técnicas de reprodução assistida. Pacientes e Métodos: Estudo caso-controle, com 11 mulheres com endometriose e 11 com os fatores tubáreo ou masculinos de infertilidade, submetidas à hiperestimulação ovariana controlada (HOC) para reprodução assistida, num total de 12 ciclos para o grupo com endometriose e 11 para o controle. Não houve diferença entre os dois grupos quanto à idade e parâmetros do ciclo de HOC. As células da granulosa murais foram coletadas de folículos pré-ovulatórios maduros no dia da captação oocitária e isoladas. Posteriormente, procedeu-se à extração do RNA (clorofórmio/ isopropanol) e à transcrição reversa. A PCR em tempo real foi realizada para quantificar os níveis de RNA mensageiro produzidos para o gene da aromatase, normalizados aos produtos do gene endógeno, b-actina (expressão relativa). Todos os experimentos foram realizados em duplicata. Resultados: não houve diferença na expressão do gene CYP19A1 nas células da granulosa luteinizadas murais de mulheres com endometriose quando comparadas ao grupo controle ( $p>0,05$; Mann Whitney), mesmo na comparação combinada considerando-se separadamente os diferentes graus de endometriose (controle vs. endometriose mínima/leve vs. Endometriose moderada/grave, p>0,05; Kruskall Wallis). Conclusão: Os resultados deste estudo sugerem que apesar de evidências prévias da reduzida atividade da aromatase nessas células na endometriose, a expressão de seu gene parece não estar afetada pela doença.

\section{SEXAGEM FETAL A PARTIR DE PLASMA MATERNO}

\section{Flávia Cappello Donabella}

Orientadora: Prof ${ }^{a}$. Dr ${ }^{\mathrm{a}}$. Ester Silveira Ramos

Dissertação de Mestrado apresentada em 28/03/2008

A determinação do sexo fetal a partir do plasma materno vem sendo muito pesquisada devido a estudos que provaram a superioridade prática da detecção de DNA livre fetal em relação às preparações de células fetais isoladas em sangue materno. Há relato da permanecência das células fetais na circulação materna por até 27 anos após o parto, 
enquanto o DNA livre fetal desaparece em aproximadamente 48 horas após o nascimento. Por se tratar de técnica não invasiva para o feto, representa maior vantagem sobre outros métodos de diagnóstico pré- natal como a amniocentese e a biópsia de vilosidade coriônica. Os objetivos deste trabalho foram: (1) Sexagem fetal a partir de plasma materno por meio do gene TSPY (Tests-Specific Protein, Y-encoded), utilizando a Reação em Cadeia da Polimerase; (2) Verificar a especificidade e sensibilidade da sexagem fetal com o gene TSPY correlacionando com o sexo fenotípico fetal verificado pela ultrassonografia e/ou pelo exame físico do recém-nascido; (3) Correlacionar a sensibilidade da sexagem com a idade gestacional e com o sexo fenotípico. Foram selecionadas 102 gestantes (idade gestacional entre duas e 40 semanas). Após a coleta do sangue periférico e da separação do plasma, realizou-se a extração de DNA e utilizou-se a técnica de NestedReação em Cadeia da Polimerase (PCR) para amplificação de sequência do gene TSPY. Foi utilizada sequência do gene da -globina como controle. Foram detectadas 40 (39,21\%) gestações com resultados positivos para o cromossomo Y e 62 $(60,78 \%)$ negativos. Em 67 casos, onde foi possível comparar os resultados do exame com sexo fetal através da ultrassonografia ou exame físico do recém-nascido, $36(59,21 \%)$ casos resultaram em positivos para TSPY, 29 (38,16\%) resultaram em negativos e dois $(2,63 \%)$ resultados foram falso-negativos. Através da análise estatística (tabela de matriz de confusão), foi encontrada uma confiabilidade positiva de $88,89 \%$ e confiabilidade negativa de $100 \%$, para gestações com menos de sete semanas e confiabilidade positiva de $100 \%$ e confiabilidade negativa de $100 \%$ para gestações com mais de sete semanas. Esses resultados confirmam a boa sensibilidade e especificidade do método, o qual poderia ser utilizado na rotina médica para auxiliar nos casos onde a sexagem fetal é necessária para tratamento fetal e/ou diminuição da ansiedade materna. No presente estudo foi escolhido, pela primeira vez na literatura envolvendo sexagem fetal a partir de sangue periférico em humanos, o gene TSPY, e foi possível detectar o sexo fetal a partir da $2^{a}$ semana de gestação. Portanto, o diagnóstico do sexo fetal a partir da $2^{\text {a }}$ semana de gestação pela técnica de Nested PCR apresentou 88,9\% de sensibilidade e $100 \%$ de especificidade.

\title{
Imunologia Básica e Aplicada
}

\section{CÉLULAS T REGULADORAS REPRESENTAM UM FATOR DE SUSCEPTIBILIDADE NA TUBERCULOSE EXPERIMENTAL}

\author{
Marina Oliveira e Paula \\ Orientadora: Prof ${ }^{\mathrm{a}}$. Dra ${ }^{\mathrm{a}}$. Vania Luiza Deperon Bonato Martins \\ Tese de Doutorado apresentada em 06/01/2009
}

Dentre as infecções bacterianas, a tuberculose é responsável pelo maior número de casos no mundo. É uma doença frequentemente fatal quando associada com cepas resistentes e extremamente resistentes às drogas, ao abandono de tratamento e imunossupressão. Dependendo da natureza e da magnitude da resposta do hospedeiro, uma inflamação excessiva, comumente não protetora nos indivíduos susceptíveis, acompanha a progressão da infecção. Nesse sentido, é de grande interesse identificar mecanismos que não somente caracterizem a evolução da infecção como também aqueles que participam no controle do dano tecidual. Neste estudo, nós usamos linhagens de animais com susceptibilidade distinta à infecção por $M$. tuberculosis com o objetivo de avaliar se a frequência e a atividade das células T reguladoras são influenciadas por características genéticas do hospedeiro e se essas diferenças poderiam representar um fator de susceptibilidade durante a tuberculose experimental. Nossos resultados mostram que tanto a frequência como a atividade supressora das células T reguladoras de animais BALB/c estava aumentada, inibindo a produção de IFN- $\gamma$ e IL-2 por células efetoras $\mathrm{CD}^{+} \mathrm{CD} 25$. Essa atividade supressora não parece ser dependente de IL-10 ou TGF- $\beta$. Do contrário, a frequência e a capacidade supressoras das células T reguladoras de animais C57BL/6 diminuíram com a infecção e, como consequência, foi verificada uma resposta proliferativa mais intensa, maior produção de IFN- $\gamma$ e IL-17, e uma eficiente restrição no crescimento bacteriano em relação aos animais BALB/c. As células T reguladoras de animais C57BL/6 regularam positivamente a produção de TGF- $\beta$. No entanto, não regularam negativamente a produção de IFN- $\gamma$. Além disso, a transferência adotiva de células T reguladoras de animais BALB/c tornou esta linhagem mais susceptível enquanto a transferência de células T reguladoras de animais C57BL/6 afetou discretamente o número de UFC nessa linhagem. Reforçando nossos dados, recentemente, foi descrito por Torcia e colaboradores (2008) que a deficiência funcional de células T reguladoras pode explicar a resistência distinta à malária em diferentes grupos étnicos da África. Nesse contexto, a ativação de células $\mathrm{T}$ reguladoras pode representar um importante aspecto a ser ressaltado no desenvolvimento de medidas profiláticas e de terapias imunológicas para doenças infecciosas em indivíduos susceptíveis. 


\title{
SELEÇÃO E PRODUÇÃO DE FRAGMENTOS DE ANTICORPOS HUMANOS (SCFV) PELA TECNOLOGIA DE "Phage Display" CAPAZES DE INIBIR A AÇÃO DA TOXINA TSTX-I in vitro E A TOXICIDADE DO VENENO DO ESCORPIÃO AMARELO - Tityus serrulatus in vivo
}

\author{
Manuela Berto Pucca \\ Orientador: Prof. Dr. José Elpidio Barbosa \\ Dissertação de Mestrado apresentada em 06/03/2009
}

No Brasil, cerca de 14 espécies de escorpiões já foram descritas, no qual Tityus é o gênero de maior importância médica. As principais espécies são T. bahiensis, T. stigmurus e T. serrulatus, cujo T. serrulatus é responsável pelo maior número de acidentes e também pelos mais graves. Anualmente, aproximadamente 36.000 acidentes são registrados, com $1 \%$ de letalidade, especialmente entre crianças, devido ao baixo peso corporal, e idosos, devido às condições físicas. Além disso, a prevalência destes acidentes é maior nas áreas urbanas, devido ao aumento de lixo e à alta proliferação de baratas, alimento preferido pelos escorpiões. Estudos do ano de 2007 no Estado de São Paulo ainda demonstram que entre os acidentes causados por animais peçonhentos, os ocasionados por escorpiões excederam os causados por aranhas e serpentes. Este dado pode ser atribuído ao fato de os escorpiões se reproduzirem por partenogênese, isto é, não existe reprodução sexual, existindo apenas fêmeas, o que facilita a proliferação. Atualmente a administração de antiveneno produzido em cavalos é reconhecida e utilizada como tratamento para acidentes causados por animais peçonhentos. Isto acontece desde 1901, quando o soro anti-botrópico e anti-crotálico passaram a ser utilizados para uso no homem, por Vital Brazil. Porém, o uso do antisoro possui algumas desvantagens: o rebanho equino é oneroso (10\% vão a óbito); os anticorpos são heterólogos, isto é, podem causar reações de hipersensibilidade como Doença do Soro e Anafilaxia; e o antisoro é produzido para todo o veneno, incluindo proteínas não tóxicas. Assim, a produção de anticorpos humanos pela tecnologia de Phage Display seria uma alternativa, por ela não utilizar o rebanho equino, eliminar as reações de hipersensibilidade e os anticorpos seriam produzidos diretamente contra as toxinas alvo.

Neste trabalho, buscou-se a produção de anticorpos monoclonais capazes de inibir a atividade do veneno de Tityus serrulatus, utilizando-se a biblioteca de fragmentos de anticorpos humanos (scFv) Griffin 1, produzida no Medical Research Council- MRC, Cambridge, Reino Unido. O protocolo adotado para a seleção foi o de imobilização das proteínas em superfície sólida. Foi realizado um total de quatro turnos de seleção, sendo que os fagos-anticorpos selecionados foram analisados por ensaio de ELISA para a escolha do turno com maior título de fagos-anticorpos reconhecedores do veneno bruto e da principal toxina do veneno, a TsTx-I. O segundo turno mostrou-se reconhecer tanto o veneno bruto como a toxina isolada, sendo escolhido para a produção de fagos-anticorpos monoclonais. Um clone, 2A, produtor de fagosanticorpos foi selecionado para a produção de fragmentos de anticorpos solúveis. Os fragmentos de anticorpos $2 \mathrm{~A}$ foram produzidos adequadamente. Posteriormente estes fragmentos foram testados quanto a sua capacidade de inibir a atividade da toxina TsTx-I in vitro e, utilizando a técnica de Patch Clamp, impediram parcialmente a ação da toxina em canais para sódio. Assim, estes fragmentos foram purificados por afinidade em coluna de níquel - Ni-NTa. Nos ensaios de inibição da letalidade houve um aumento da sobrevida dos animais.

\section{CONSTRUÇÃO DE UMA VACINA DNA BIVALENTE PARA TUBERCULOSE EXPRESSANDO A PROTEÍNA gD DO HSV-1 E OS EPÍTOPOS DA Hsp65 MICOBACTERIANA}

\author{
Wendy Martin Rios \\ Orientador: Prof. Dr. Celio Lopes Silva \\ Dissertação de Mestrado apresentada em 31/03/2009
}

A tuberculose (TB) é uma doença infecciosa causada pelo Mycobacterium tuberculosis, que necessita de uma vacina mais efetiva, pois a única vacina licenciada apresenta eficácia variando entre 0 a $80 \%$. Entre as estratégias em desenvolvimento destaca-se a vacina DNAhsp65, que consiste de um plasmídeo carregando o gene hsp65 de Mycobacterium leprae, que demonstra eficácia na profilaxia da TB. Como as HSPs são proteínas altamente conservadas e podem desencadear respostas auto-imunes, seria interessante o desenvolvimento de uma vacina baseada na utilização apenas dos epítopos da proteína Hsp65 reconhecidos por células T. Estudos com vacinas de DNA baseadas na fusão de peptídeos à glicoproteína $\mathrm{D}(\mathrm{gD})$ do Herpes Vírus Tipo-1 têm mostrado maior ativação de linfócitos $\mathrm{T}$ e $\mathrm{B}$ peptídeos-específicos. Dessa forma, o presente trabalho teve como objetivo a construção e avaliação da imunogenicidade de vacinas de DNA constituídas pelo gene da proteína gD e a sequência gênica que codifica os cinco epítopos da Hsp65. Para a obtenção da sequência codificadora dos epitopos, denominada Vac1, foi realizada uma síntese gênica e em seguida, essa sequência foi fusionada ao gene que codifica a $\mathrm{gD}$ em dois sítios presentes em seu interior, no sítio da enzima ApaI e entre os sítios das 
enzimas Pvull e ApaI, com a retirada de uma porção central da gD. Além dessas construções, também foi realizada a construção da Vac2 pela ligação de fragmentos Vac1 que em seguida foi fusionada ao gene da gD no sítio de ApaI. Essas construções, gDVac1AA, gDVac1PA e gDVac2 foram clonadas no vetor pVAX1 e avaliadas quanto a expressão das proteínas. Após a caracterização, camundongos foram imunizados com quatro doses das vacinas e a imunogenicidade avaliada após trinta dias da última dose. Os ensaios ex vivo foram realizados com o soro para dosagem de anticorpos e com as células do baço, que foram estimuladas com as proteínas Hsp65, Vac1 e Vac2. Como resultado, obtivemos duas construções vacinais, pVAXgDVac1PA e pVAXgDVac2, eficientes em induzir anticorpos do subtipo IgG2a específicos a proteína e aos epitopos da Hsp65 e as três vacinas, pVAXgDVac1AA, pVAXgDVac1PAe pVAXgDVac2, foram capazes de induzir proliferação de linfócitos T e produção de IFN-y após estímulo ex vivo. As vacinas foram, portanto, eficazes em desencadear um padrão de resposta Th1 importante no combate ao bacilo M. tuberculosis.

\title{
Neurologia
}

\section{ESTRATÉGIAS TERAPÊUTICAS NO TRATAMENTO ENDOVASCULAR DOS ANEURISMAS SACULARES INTRACRANIANOS}

\author{
Daniel GiansanteAbud \\ Orientador: Prof.Dr. Antonio Carlos dos Santos \\ Tese de Doutorado apresentada em 23/03/2009
}

Introdução: Nosso objetivo foi avaliar os resultados técnicos, clínicos e angiográficos de uma série de aneurismas intracranianos não cirúrgicos tratados por via endovascular no Hospital das Clínicas da Faculdade de Medicina de Ribeirão Preto da USP e comparar com os dados disponíveis na literatura atualmente. Materiais e Métodos: De agosto de 2005 a novembro de 2008, 137 aneurismas saculares foram tratados em 106 pacientes, 101 aneurismas não-rotos em 75 pacientes e 36 rotos em 31 pacientes. Todos foram incluídos de maneira prospectiva, sendo analisados os dados demográficos, tipo de tratamento, complicações, resultados clínicos e angiográficos. Foram realizadas análises estatísticas para estudo dos dados. Resultados: Sessenta e três aneurismas (45.99\%) foram tratados pela técnica simples; 52 (37,96\%), por remodelagem por balão; 15 (10,95\%), por remodelagem por stent; e 7 (5,11\%), por oclusão terapêutica da carótida interna. Complicações técnicas ocorreram em 9 (6,57\%) aneurismas, $3(2,19 \%)$ sintomáticas e $6(4,38 \%)$ assintomáticas. Foram observadas $6(5,66 \%)$ complicações clínicas, 3 (2,83\%) transitórias e $3(2,83 \%)$ permanentes. Seguimento angiográfico foi realizado para 97 aneurismas (70,80\%) e clínico para 77 pacientes (72,64\%). Retratamento foi necessário em 8 aneurismas, correspondendo a 8,25\% dos aneurismas controlados. Conclusão: Os resultados encontrados nesta série são semelhantes aos encontrados na literatura. Os diferentes tipos de tratamento acarretam riscos semelhantes de complicações. A remodelagem por stent e a oclusão terapêutica da carótida interna são mais estáveis, ao longo do tempo, em aneurismas grandes e gigantes.

\section{Oftalmologia, Otorrinolaringologia e Cirurgia de Cabeça e Pescoço}

\section{ANÁLISE DA OCULOMOTRICIDADE EM SUJEITOS COM E SEM INCLINAÇÃO LATERAL DA CABEÇA}

\author{
Blacy Cella Gulfier \\ Orientador: Prof. Dr. José Fernando Colafêmina \\ Tese de Doutorado apresentada em 05/01/2009
}

Este trabalho objetivou verificar a correlação entre a alteração postural, a inclinação lateral da cabeça e os resultados da oculomotricidade. Para tanto, a pesquisa foi realizada com dois grupos de sujeitos dos gêneros feminino e masculino, com idades variando de 20 a 60 anos, identificados como: GT- Grupo de 30 sujeitos com alteração postural, inclinação lateral da cabeça à direita ou à esquerda e GST- Grupo controle composto de 50 sujeitos sem alteração postural e sem inclinação lateral da cabeça. Tais sujeitos não apresentavam alterações neurológicas, queixas visuais, deformidades 
posturais congênitas e nem alterações posturais por traumas. Os sujeitos foram recrutados no Hospital das clínica da Faculdade de Medicina de Ribeirão Preto da Universidade de são Paulo (HCFMRP-USP) e passaram por uma avaliação postural e de oculomotricidade. Para a avaliação postural utilizaram-se marcações adesivas colocadas na testa e no queixo, na parte fronto lateral, de acordo com linha dos olhos, e nos ombros. Tais marcações serviram como referência para análise e classificação do sujeito com e sem inclinação lateral da cabeça. Para os testes de oculomotricidade utilizou-se o programa VEC. WIN Digital 1.5, com o equipamento da Neurograff Eletromedicina (unidade de amplificação). Considerou-se como material para a pesquisa a análise do desempenho dos sujeitos nos seguintes testes: latência, velocidade e precisão dos movimentos sacádicos fixos e randomizados para a direita e para a esquerda, rastreio pendular em $0.10 \mathrm{~Hz}, 0.20 \mathrm{~Hz}$ e $0.40 \mathrm{~Hz}$, optocinético, no que se refere ao ganho e à velocidade angular da componente lenta, para a direita e para a esquerda. Mediante os resultados e as análises estatísticas dos mesmos, verificou-se que na avaliação intra grupo com os sujeitos do grupo com inclinação lateral da cabeça à direita ou à esquerda não houve diferenças significantes da oculomotricidade, mas, quando relacionados os sujeitos do grupo com inclinação lateral da cabeça e sem inclinação lateral da cabeça, houve diferenças significantes nos seguintes testes: movimentos sacádicos fixos na latência e na velocidade, movimentos sacádicos randomizados na latência e na velocidade, ganho do rasteio pendular em $0.10 \mathrm{~Hz}$, optocinético e velocidade angular da componente lenta e ganho.

\section{PRESENÇA DE Acanthamoeba NA CONJUNTIVA DE NADADORES HÍGIDOS}

\section{Luis Antonio Gorla Marcomini}

Orientador: Prof. Dr. Sidney Júlio de Faria e Sousa

Tese de Doutorado apresentada em 06/02/2009

Introdução: A Acanthamoeba é uma amoeba de vida livre, que pode causar ceratite de difícil diagnóstico e tratamento, particularmente em usuários de lentes de contato. Como esses protozoários já foram isolados de águas de piscinas, o objetivo deste estudo foi o de observar se a conjuntiva de nadadores hígidos pode albergar Acanthamoeba. Material e Método: Noventa e dois indivíduos hígidos de duas academias de esportes dotadas de piscinas cobertas e aquecidas, pertencentes a uma mesma companhia, foram estudados entre 2007 e 2008, após assinarem termo de consentimento. Os critérios de exclusão foram: uso de lentes de contato, uso de qualquer medicação ocular ou qualquer antibiótico sistêmico, idade inferior a 18 anos, e a utilização de ambas as piscinas durante o experimento. $\mathrm{O}$ estado de higidez dos participantes foi atestado pela equipe médica das academias. O estudo foi dividido em duas fases. Uma das academias, identificada como "A" tinha em torno de 33 anos de construção. A outra, identificada como "B", tinha cinco anos. Primeira fase: Foram coletados raspados conjuntivais de 30 nadadores e 13 não-nadadores da academia "A" e de 11 nadadores da academia "B". Ao mesmo tempo, foram coletadas duas amostras de água (uma pela manhã e outra à noite) de cada uma das piscinas, durante sete dias consecutivos. Então, a piscina "A" foi esvaziada e submetida a uma limpeza diferenciada. Os procedimentos de limpeza e manutenção de ambas as piscinas passaram a ser feitos três vezes por semana ao invés de uma vez como era até então. Segunda fase: seis meses mais tarde, amostras de água de ambas as piscinas foram coletadas novamente, segundo o mesmo esquema da primeira fase. Raspados conjuntivais de nadadores da piscina "A" foram coletados e separados em dois grupos: um grupo constituído por 18 nadadores que ainda não haviam sido testados, e o outro constituído por 16 nadadores que já haviam sido testados na primeira fase. Na piscina "B" foram coletados raspados conjuntivais de 20 nadadores que não haviam sido testados na primeira fase. O material foi coletado com uma escova de cerdas de nylon, especialmente desenhada para este estudo; cultivado em Agar não nutriente com cobertura de Escherichia coli; e, observado diariamente ao microscópio óptico, para pesquisa de cistos e trofozoítos de Acanthamoeba, durante 14 dias. Resultados: Primeira fase: A porcentagem de contaminação da conjuntiva tarsal superior de nadadores da piscina "A" foi de 76,7\% (23/30); nenhum dos 13 não-nadadores da academia "A" e nenhum dos 11 nadadores da "B" foram positivos. A taxa de contaminação dos nadadores da academia "A" foi significativamente maior que as taxas de contaminação dos não-nadadores (Teste Exato de Fisher p<0,0001) e dos nadadores da academia "B" (Teste Exato de Fisher p=0,0001). A porcentagem de contaminação das amostras de água das piscinas "A" e "B" foi, respectivamente, $85,7 \%$ (12/14) e 35,7\% (5/14). Essa diferença foi estatisticamente significativa (Teste exato de Fisher p=0,0183). Segunda Fase: em ambas as piscinas a porcentagem de contaminação das amostras de água passou a ser de 14,3\% (2/14). A mudança na taxa de contaminação na piscina "A" de 85,7\% para 14,3\% foi estatisticamente significante (Teste de McNemar $\mathrm{p}=0,0094)$. A mudança na taxa de contaminação da piscina "B" de 35,7\% para 14,3\% não foi estatisticamente significante (Teste de McNemar p=0,3711). A porcentagem de contaminação da conjuntiva tarsal dos 18 nadadores da piscina "A" foi de 5,5\% (1/18). Nenhum dos 20 nadadores da piscina "B" estava contaminado. A diferença na proporção de contaminação dos nadadores de ambas as piscinas não foi estatisticamente significante (Teste Exato de Fisher p=0,4737). A diferença 
entre as taxas de contaminação dos 14 nadadores da primeira fase $(78,6 \%)$ e dos 18 nadadores da segunda fase $(5,5 \%)$ da piscina "A" foi estatisticamente significante (Teste Exato de Fisher p<0,0001). A mudança na taxa de contaminação de $75 \%$ para $18,7 \%$ entre os 16 nadadores da piscina "A", que foram testados em ambas as fases, foi estatisticamente significante (McNemar $\mathrm{p}=0,0077$ ). Conclusões: pudemos concluir que: 1) a conjuntiva de nadadores hígidos pode albergar Acanthamoeba; 2) a chance de se encontrar Acanthamoeba na conjuntiva de nadadores hígidos está provavelmente relacionada com o grau de contaminação da água da piscina por esse protozoário. 3) nadadores com resultado positivo para Acanthamoeba podem tornar-se negativos com a redução da contaminação da piscina.

\title{
MEMÓRIA SENSORIAL E O PROCESSAMENTO TEMPORAL EM INDIVÍDUOS COM HISTÓRIA PREGRESSA DE PREMATURIDADE
}

\author{
Mônica Pires de Castro Mendonça \\ Orientador: Prof. Dr. José Antonio A. de Oliveira \\ Tese de Doutorado apresentada em 20/02/2009
}

Introdução: Os mecanismos fisiológicos do sistema nervoso auditivo central estão relacionados com os processos temporais de memória e atenção, os quais estão intimamente relacionados ao processamento de linguagem e da aprendizagem. Compreender como tais mecanismos desenvolvem-se em crianças com história de prematuridade, por meio da avaliação comportamental e objetiva das habilidades auditivas tem sido objeto de pesquisas na área da fonoaudiologia, otologia e neurociência. Objetivo: avaliar as habilidades auditivas de memória sensorial e de processamento temporal de indivíduos nascidos pré-termo e a termo, além de identificar se a presença dos fatores de risco, como doenças das vias aéreas superiores e otite média serosa, durante os primeiros anos de vida, interfere no desenvolvimento da função auditiva. Casuística e métodos: pesquisa do tipo observacional, descritiva, prospectiva e transversal. Aprovada sob o protocolo número 134/03 pela Comissão de Ética em Pesquisa da Universidade de Franca. Participaram 36 sujeitos, na faixa etária entre nove anos e dezoito anos, os quais foram subdivididos em dois grupos, o grupo controle (GC) com 20 sujeitos nascidos a termo e o grupo de pesquisa (GP) com 16 sujeitos com história de nascimento prematuro. Como procedimentos de coleta de dados foram realizados: a entrevista inicial; a avaliação audiológica (audiometria tonal limiar, pesquisa do limiar de percepção da fala, pesquisa timpanométrica e do reflexo acústico; PEATE); a avaliação otorrinolaringológica; a avaliação das habilidades auditivas, por meio da pesquisa do potencial evocado auditivo de longa latência - Mismatch Negativity (MMN) e testes de Padrão de Duração e Padrão de Frequência. Na análise dos dados utilizou-se o teste $t$ de Students e o Teste Exato de Fischer, ambos com valores significativos de $p<0,05$. Resultados: não houve diferença estatisticamente significante entre os grupos (GC e GP), para os valores das médias da latência e amplitude do MMN. Observou-se que os valores das médias de latência e amplitude do MMN foram muito próximos, nas derivações CZA1 e CZA2, em ambos os grupos. O número de sujeitos com alteração no teste de padrão de duração é ligeiramente maior no GP (06-37,5\%) do que no GC (02-10\%), porém sem diferença significativa. No teste padrão de frequência os grupos GC e GP apresentaram a mesma quantidade numérica de exames alterados, porém, proporcionalmente maior para o grupo pesquisa ( 7 - 43,75\%), mas sem significância estatística. Aspecto como a presença de alterações auditivas associadas às alterações de vias aéreas superiores e otite média apresentou diferença significativa para o grupo masculino. Conclusão: As análises das médias da latência e da amplitude do MMN, assim como, as médias percentuais de acertos dos testes de padrão de duração e frequência não apresentaram diferenças estatísticas significantes entre os grupos controle e pesquisa. A presença de fatores de risco, como as otites médias e as alterações de vias aéreas superiores, pode influenciar prejudicialmente o processo de maturação e desenvolvimento das habilidades auditivas. A prematuridade, por si só, para este grupo, não determinou alterações no desenvolvimento das habilidades auditivas e de linguagem.

\section{CARACTERÍSTICAS DO PISCAR ESPONTÂNEO EM INDIVÍDUOS COM CEGUEIRA BILATERAL POR GLAUCOMA}

\author{
Kledione Veiga Falcão \\ Orientador: Prof. Dr. Jayter Silva de Paula \\ Dissertação de Mestrado apresentada em 26/02/2009
}

Objetivo: Verificar algumas características da dinâmica do piscar espontâneo e a distância margem palpebral centro da pupila (DMCP) superior em pacientes com cegueira bilateral secundária a glaucoma crônico avançado, comparando tais parâmetros com aqueles de pessoas sem afecção ocular. Casuística e Métodos: Foram analisados, através de filmagem de um marcador colocado na pálpebra superior direita, vinte olhos divididos em dois grupos: Grupo 1, composto 
por onze pessoas sem afecções oculares e Grupo 2, composto por nove pacientes cegos bilateralmente por glaucoma. Após da captação das imagens, por cinco minutos, os dados obtidos da variação espacial da pálpebra superior, foram trabalhados em software específico, a fim de se extrair os seguintes parâmetros: frequência, amplitude e duração da fase descendente do piscar. Ademais, a DMCP foi aferida em ambos os grupos e os dados foram analisados estatisticamente. Resultados: O Grupo 2 apresentou médias significativamente diferentes do Grupo 1 nas variáveis frequência ( $1.13 \pm 0.20$ e $10.65 \pm 1.52$ eventos/ minuto; respectivamente; $\mathrm{P}<0,001)$ e amplitude do piscar espontâneo $(2.68 \pm 0.42$ e $4.09 \pm 0.44 \mathrm{~mm}$, respectivamente; $\mathrm{P}=0,025)$. Não se observou diferenças significativas nas comparações das médias da duração da fase descendente $(0.15 \pm 0.01 \mathrm{~s}$ - Grupo 1 e $0.16 \pm 0.01 \mathrm{~s}-$ Grupo $2 ; \mathrm{P}=0,18)$ e da DMCP $(2.50 \pm 0.21 \mathrm{~mm}-\mathrm{Grupo} 1 \mathrm{e} 2.00 \pm 0.30 \mathrm{~mm}$ - Grupo 2; P= 0,18). Conclusão: Indivíduos que são cegos bilateralmente por glaucoma avançado apresentaram frequência e amplitude menores do piscar espontâneo, quando comparado ao grupo controle. Não houve diferença significativa na comparação dos parâmetros duração e DMCP. Tais achados apontam para a possibilidade de entendimento do glaucoma como uma doença com componentes neurodegenerativos do sistema nervoso central.

\title{
EMPREGO ORAL DE BENZODIAZEPÍNICOS COMO MEDICACÃO PRÉ-ANESTÉSICA EM BLEFAROPLASTIAS SUPERIORES: UMA COMPARAÇÃO COM CLONIDINA
}

\author{
Rejane Dantas Rodrigues Gonçalves \\ Orientador: Prof. Dr. Antonio A. Velasco e Cruz \\ Tese de Doutorado apresentada em 09/03/2009
}

Objetivo: Avaliar os efeitos do emprego oral do cloridrato de clonidina $(0,150 \mathrm{mg})$ e dois agentes benzodiazepínicos (1mg de alprazolam ou 15mg de midazolam) administrados de forma isolada, ou combinada, como medicação pré-anestésica, no que tange ao grau de ansiedade, percepção de dor transoperatória, sinais vitais e grau de sedação obtidas em cirurgias de blefaroplastia superior. Métodos: Foi desenvolvido um ensaio clínico prospectivo, randomizado, controlado com 98 pacientes, risco anestésico baixo e moderado, divididos em 7 grupos de 14 pacientes: Grupo 1 (G1) alprazolam; Grupo 2 (G2) midazolam; Grupo 3 (G3) clonidina; Grupo 4 (G4) alprazolam + clonidina; Grupo 5 (G5) midazolam + clonidina; Grupo 6 (G6) placebo e Grupo 7 (G7) sem medicação. Todos os pacientes foram avaliados quanto ao grau de ansiedade e dor intraoperatórias, variação entre os períodos pré e trans-operatórios da pressão arterial (sistólica e diastólica), pulsação $(\mathrm{P})$, frequência respiratória (FR), frequência cardíaca (FC) e temperatura (T) e sedação intra-operatória. Resultados: A análise de variância não-paramétrica Kruskal-Wallis demonstrou que a redução da ansiedade trans-operatória foi maior no G1 e G2. Os dois agentes benzodiazepínicos, isoladamente ou em combinação com a clonidina, reduziram significativamente a percepção de dor intra-operatória. A análise de variância unifatorial com teste de Tukey mostrou que na administração isolada das três drogas, a clonidina apresentou maior efeito hipotensor, tanto na pressão arterial sistólica como na diastólica. O uso isolado ou combinado de midazolam reduziu significativamente a frequência respiratória em relação aos pacientes que não fizeram uso da medicação. O grau de sedação do midazolam foi igual quando administrado de maneira isolada ou combinada. Conclusão: A sedação oral com os dois agentes benzodiazepínicos mostrou ser eficiente e segura. O único efeito adicional da administração combinada com a clonidina é a amplificação do efeito hipotensor.

\section{EFEITOS DA EXPOSIÇÃO À FUMAÇA DE CIGARRO SOBRE A CILIOGÊNESE E A FORMAÇÃO DE BIOFILMES BACTERIANOS NO EPITÉLIO RESPIRATÓRIO}

\author{
Edwin Tamashiro \\ Orientadora: Prof ${ }^{a}$. Dra ${ }^{\mathrm{a}}$. Wilma T. Anselmo-Lima \\ Tese de Doutorado apresentada em 27/03/2009
}

Introdução: Recentes evidências têm demonstrado que a presença de biofilmes bacterianos e a exposição à fumaça de cigarro podem participar da fisiopatogenia da rinossinusite crônica (RSC). No entanto, não existem estudos demonstrando se a exposição à fumaça de cigarro favorece o desenvolvimento de RSC através do crescimento de biofilmes bacterianos sobre o epitélio respiratório. Objetivos: Avaliar os efeitos que a exposição à fumaça de cigarro exerce sobre o processo de ciliogênese e constituição da barreira epitelial, bem como avaliar os efeitos diretos e indiretos (mediado pelo epitélio respiratório) sobre o crescimento de biofilmes. Materiais e Métodos: Culturas de epitélio nasal de camundongos crescidas em interface-ar líquido foram expostas a diferentes concentrações de extrato de fumaça de cigarro (EFC) ou condensado de fumaça de cigarro (CFC) durante o processo de proliferação e diferenciação celular ao longo de 15 dias. No final do experimento, foram avaliados a resistência elétrica transepitelial e os aspectos morfológicos da superfície por meio de microscopia eletrônica de varredura (MEV). Um grupo de culturas foram infectadas com P.aeruginosa em sua superfície 
e avaliadas quanto à formação de biofilmes por meio de MEV. Paralelamente, amostras bacterianas coletadas de pacientes com RSC foram incubadas com fumaça de cigarro e quantificadas a formação de biofilme pelo ensaio modificado de biofilme de Calgary. Resultados: A exposição ao EFC a diluições menores do que 1:100 e ao CFC a concentrações maiores do que $30 i ̀ g / m l$ promoveram uma significativa redução tanto em porcentagem de área ciliada como em tamanho dos cílios. A incubação de bactérias com EFC diluídas a 1:10 promoveu um aumento significativo na formação biofilmes em $39 \%$ das bactérias. Entretanto, a exposição de culturas celulares ao EFC ou ao CFC não promoveu alterações significativas da formação de biofilmes em sua superfície. Conclusões: A exposição à fumaça de cigarro promoveu uma diminuição do processo de ciliogênese em caráter dosedependente, sem causar alterações na confluência celular. A exposição direta das bactérias ao EFC a diluição de 1:10 promoveu um aumento significativo na formação de biofilme. No entanto, quando mediado pelo epitélio respiratório, não promoveu alterações significativas no crescimento de biofilmes.

\title{
Ortopedia, Traumatologia e Reabilitação
}

\section{OS EFEITOS DA IRRADIAÇÃO COM LASER DE BAIXA POTÊNCIA NA REGENERAÇÃO DO NERVO FIBULAR COMUM DO RATO SUBMETIDO A LESÃO POR ESMAGAMENTO}

\author{
Rodrigo Antonio Carvalho Andraus \\ Orientador: Prof. Dr. Claudio Henrique Barbieri \\ Dissertação de Mestrado apresentada em 10/02/2009
}

A regeneração dos nervos periféricos é um processo natural, que demanda um período longo para se completar, havendo algumas evidências de que agentes físicos, inclusive o laser, podem acelerá-lo. O objetivo primordial deste estudo foi analisar a influência da irradiação com o laser de baixa potência (AsGaAL) sobre a regeneração nervosa, num modelo de lesão por esmagamento do nervo fibular comum de ratos. O objetivo secundário foi avaliar a concordância entre os índices funcionais do nervo fibular (PFI) e o dos nervos ciático (SFI) e tibial (TFI), segundo os métodos propostos por dois autores diferentes. Foram utilizados 35 ratos Wistar (130 dias de idade, massa corporal média de 240 gramas), divididos em três grupos de dez animais cada, conforme o procedimento realizado (1: esmagamento, sem tratamento; 2: esmagamento e tratamento simulado; 3: esmagamento e tratamento efetivo) e num grupo de cinco animais intactos, para controle. A lesão por esmagamento do nervo fibular comum foi obtida pela aplicação de uma carga de $5 \mathrm{Kgf}$ por dez minutos, com uma pinça especialmente confeccionada para esse fim. A irradiação com o laser foi iniciada no primeiro dia pós-operatório, empregando um equipamento de laser AsGaAL de baixa potência (potência de $100 \mathrm{~mW}$, comprimento de onda de $830 \mathrm{~nm}$, dose de 140 $\mathrm{J} / \mathrm{cm}^{2}$ ) de emissão contínua, pelo método transcutâneo pontual de contato, e continuada por 21 dias consecutivos. Os resultados foram avaliados pela medida da velocidade de marcha do animal e do índice funcional do fibular (PFI, de peroneal functional index). A massa corporal, a velocidade de marcha e o PFI foi medido antes da operação e no $21^{\circ}$ dia pósoperatório, o PFI por meio de um programa de computador específico para esse fim, utilizando duas fórmulas diferentes. Os resultados mostraram que a massa corporal aumentou em todos os grupos, sem diferença estatística entre os períodos. A velocidade de marcha diminuiu, também sem diferença estatística em todos os grupos. O PFI aumentou em todos os grupos e com as duas fórmulas utilizadas na sua medida, mas no Grupo 3, embora sem diferença estatística nos períodos pré e pós-operatórios, evidenciando que a irradiação com o laser interferiu significativamente na regeneração do nervo fibular esmagado. Houve uma concordância moderada entre o PFI e o SFI, maior no período pós-operatório, demonstrando que o SFI pode ser empregado para a avaliação do nervo fibular, o que, entretanto, não é recomendável.

Concluímos que a irradiação do laser de baixa potência influenciou significantemente na regeneração do nervo fibular comum esmagado de ratos, pela medida do índice funcional do peroneiro.

\section{ANÁLISE DE UM TESTE DE AVALIAÇÃO DA SENSIBILIDADE FUNCIONAL DA MÃO}

\author{
Daniela Neto Aguiar \\ Orientadora: Prof $^{a}$ Dr $^{\mathrm{a}}$ Marisa de Cássia R. Fonseca \\ Dissertação de Mestrado apresentada em 26/02/2009
}

Com a necessidade descrita na literatura de se obterem métodos mais confiáveis, este estudo objetivou analisar a confiabilidade e a validade do método pick-up de Moberg, além de investigar o efeito da idade, gênero e dominância das 
mãos. Participaram do estudo 117 indivíduos de ambos os sexos, sendo 103 normais, sem lesão nervosa, e 14 com lesão do nervo mediano já tratado e com, no mínimo, um ano de pós-operatório. O pick-up test foi aplicado por dois avaliadores em indivíduos voluntários que manipularam doze objetos metálicos em duas fases distintas: olhos abertos, mão não-dominante/dominante, e olhos fechados, mão não-dominante/dominante. Os resultados foram analisados a partir do teste nãoparamétrico de Wilcoxon e Mann-Whitney que avaliou a normalidade. A confiabilidade intra e a interavaliador foram analisadas pelo coeficiente de correlação intraclasse que encontrou uma alta correlação intra-avaliador ( $\mathrm{r}=0,92)$, para o avaliador 2, e uma alta correlação interavaliador $(\mathrm{r}=0,96)$, para a situação olhos fechados/membro dominante. Para a comparação da dominância dos membros, foi utilizado o teste de Friedman que indicou maior rapidez do membro dominante, para o grupo de não-lesados, enquanto, para o grupo de lesados, as médias dos tempos médios do pick-up revelaram sua lentidão na fase de reconhecimento dos objetos, principalmente a moeda pequena e a porca pequena. Quanto à diferença entre os gêneros, o teste indicou que os homens foram mais rápidos. Para a análise entre os indivíduos nãolesados e lesados, foram utilizados as faixas de referência de 95\%, o teste de Friedman e um índice das diferenças percentuais da média dos tempos do pick-up test que não indicaram a efetividade do método, apesar de a amostra de lesados ter sido pequena. Portanto, o pick-up test, apesar de ser ainda muito utilizado pelos profissionais, de acordo com estes resultados, não se mostrou um teste preciso na análise da sensibilidade funcional da mão, nas condições deste estudo. No entanto, são necessários novos estudos com um período de pós-operatório maior, pois alguns autores defendem que o período de restabelecimento do nervo pode chegar até 5 anos após a cirurgia.

\title{
ANÁLISE FUNCIONAL, BIOMECÂNICA E HISTOLÓGICA DE MÚSCULOS GASTROCNÊMIOS DE RATAS SUBMETIDOS À LESÃO EXPERIMENTAL E TRATADOS POR ELETROACUPUNTURA
}

\author{
Rodrigo Okubo \\ Orientador: Prof. Dr. Antonio Carlos Shimano \\ Dissertação de Mestrado apresentada em 27/02/2009
}

O objetivo deste trabalho foi avaliar funcional, biomecânica e histologicamente a influência da eletroacupuntura em músculos gastrocnêmios submetidos à lesão experimental por mecanismo de impacto. Foram utilizadas 96 ratas Wistar, de peso inicial de 239,93 $\pm 12,45$ g, divididas em grupos experimentais: grupo lesão 3 e 5 dias (GL3 e GL5); grupo tratado com eletroacupuntura 3 e 5 dias (GT3 e GT5) e grupo simulado, utilizando ditos não-pontos, 3 e 5 dias (GS3 e GS5). O controle (GC) foi composto pelos músculos contralaterais à pata lesada dos grupos GT3 e GT5; A lesão direta foi provocada no músculo gastrocnêmio por mecanismo de impacto com a queda de uma carga de $200 \mathrm{~g}$ de altura de $30 \mathrm{~cm}$. Os pontos E-36 (Zusanli) e BP-6 (Sanyinjiao) foram localizados e estimulados através do localizador de pontos Plexus Point Scanner e do aparelho eletroestimulador Accurate Pulse 195 Microprocessado (VMV Biotherapy - São Carlos / SP). A análise funcional foi designada de forma a realizar a quantificação do tempo do passo da pata lesada. Esta análise foi realizada através da filmagem da caminhada dos animais sobre um trilho de acrílico, sendo gravadas as imagens antes da lesão, um dia após a lesão e, neste mesmo dia, após a aplicação da eletroacupuntura, tanto no grupo simulado como no grupo tratado. Os músculos gastrocnêmios foram submetidos a ensaios mecânicos na máquina universal de ensaio EMIC@ e calculadas as respectivas propriedades mecânicas: força máxima e rigidez. A análise histológica foi utilizada para determinar a extensão da regeneração e reparo, verificando área de lesão. O músculo removido foi fixado em formol 10\% por sete dias, desidratado com diferentes concentrações de álcool, incluído em parafina e os cortes semi-finos ( $6 \mu \mathrm{m}$ de espessura) foram corados com H\&E. A análise da marcha demonstrou constantes de tempos, para o grupo simulado, de: 0,53 $\pm 0,12$ para antes da lesão, 0,20 \pm 0,05 para o animal lesado e, 0,33 \pm 0,05 para depois da eletroacupuntura. Para o grupo tratado, 0,52 $\pm 0,09$ para antes da lesão, 0,22 \pm 0,06 para o animal lesado e, 0,36 $\pm 0,03$ para depois da eletroacupuntura Os valores médios das forças máximas e rigidez foram, respectivamente: para GC de $(37,21 \pm 4,28) \mathrm{N} \mathrm{e}(4,30 \pm 0,79) \mathrm{N} / \mathrm{mm}$, GL3 de $(32,32 \pm 3,00) \mathrm{N} \mathrm{e}(3,7 \pm 0,9) \mathrm{N} / \mathrm{mm}$, para o GT3 de $(29,93 \pm 5,23) \mathrm{Ne}(3,83 \pm 0,90) \mathrm{N} / \mathrm{mm}$, e, para o GS3 de $(31,78 \pm 3,71) \mathrm{Ne}(4,25 \pm 0,69) \mathrm{N} / \mathrm{mm}$. Além disso, para GL5 de $(36,02 \pm 6,26) \mathrm{Ne}(4,11 \pm 1,17) \mathrm{N} / \mathrm{mm}$, GT5 de $(36,37 \pm 4,98) \mathrm{N} \mathrm{e}(4,70 \pm 1,14) \mathrm{N} / \mathrm{mm}$, e, para o GS5 de $(36,34 \pm 5,33) \mathrm{Ne}(4,50 \pm$ $0,71) \mathrm{N} / \mathrm{mm}$. A análise histológica, dos grupos de 3 dias, lesado, tratado e placebo, mostrou áreas de lesão evidente, observando infiltrado de células em locais de hematoma, não demonstrando diferenças entre os grupos. Nos grupos de 5 dias, o tratado apresentou melhora em relação aos demais grupos. Os resultados encontrados sugerem uma melhora funcional e histológica com a utilização da técnica da eletroacupuntura, porém não foi observada melhora biomecânica. 


\title{
Patologia
}

\section{AVALIAÇÃO DA PROGRESSÃO TUMORAL DO CÂNCER DE LARINGE ASSOCIADA À INFECÇÃO PELO PAPILOMAVÍRUS HUMANO (HPV)}

\author{
Fabiana Alves de Miranda \\ Orientador: Prof. Dr. Edson Garcia Soares \\ Dissertação de Mestrado apresentada em 30/03/2009
}

Para que ocorra a transição do epitélio normal de laringe para carcinoma escamoso é necessário um processo de múltiplas etapas tal como exposição prolongada ao fumo e álcool e uma possível associação à infecção pelo HPV. Vários tipos de marcadores moleculares vêm sendo estudados na carcinogênese da laringe, entre eles proteínas associadas a apoptose (bcl-2 e PARP-1) assim como proteínas envolvidas em múltiplos processos biológicos como a Galectina-3. Neste estudo foram realizadas análise imunoistoquímica quantitativa e qualitativa para bcl-2, PARP-1 e galectina-3 em 65 pacientes diagnosticados com câncer de laringe subdivididos em: carcinoma de laringe in situ (CLIS), carcinoma de laringe com metástase (CLM), sem metástase (CLS) e linfonodos cervicais (LC). A detecção e tipificação do HPV foram realizadas pela reação em cadeia da polimerase (PCR) e os tipos de HPV avaliados foram HPV 6, 11, 16, 18, 31 e 33. Na avaliação quantitativa de galectina-3 observou-se um significativo aumento de expressão no carcinoma invasivo de laringe (CLS e CLM) quando comparado com carcinoma in situ (CLIS), podendo concluir que essa proteína seria um bom marcador pra progressão de câncer de laringe. Para as proteínas PARP-1 e bcl-2 não houve diferença nos níveis de expressão nos grupos analisados. Na análise qualitativa PARP-1 apresentou uma homogeneidade de marcação tanto alta como baixa entre os grupos. Em relação à Galectina-3 observou-se um predomínio de casos com alta expressão, diferentemente da proteína bcl2 onde o predomínio foi de baixa expressão em todos os casos de carcinoma de laringe e seus respectivos linfonodos metastáticos. Dos 65 pacientes, 55 (84,6\%), foram positivos para beta-globina e 7 (12.7\%) dos 55 pacientes foram positivos para HPV. Não foi possível verificar quaisquer correlações entre as proteínas Galectina-3, bcl-2 e PARP-1 e o HPV devido ao baixo índice de casos positivos.

\section{Saúde da Criança e do Adolescente}

\section{AVALIAÇÃO DA HIGIENE ORAL COM CLOREXIDINA A 0,12\% SOBRE A INCIDÊNCIA DE PNEUMONIA NOSOCOMIAL EM CRIANÇAS NO PÓS-OPERATÓRIO DE CIRURGIA CARDÍACA}

\author{
Andréa Duarte Nascimento Jácomo \\ Orientadora: Prof ${ }^{\mathrm{a}}$. Dr ${ }^{\mathrm{a}}$. Ana Paula de Carvalho Panzeri Carlotti \\ Dissertação de Mestrado apresentada em 03/02/2009
}

As infecções hospitalares representam uma causa importante de aumento da morbimortalidade e dos custos da internação de pacientes, sobretudo daqueles internados em centros de terapia intensiva (CTI) no pós-operatório de cirurgia cardíaca. A análise do perfil epidemiológico das infecções hospitalares no CTI-Pediátrico (CTI-P) do Hospital das Clínicas da Faculdade de Medicina de Ribeirão Preto da Universidade de São Paulo (HCFMRP-USP) demonstrou incidência de pneumonia hospitalar de $31,1 \%$ e taxa de pneumonia associada à ventilação mecânica (PAV) de 23,81 por 1000 ventiladores-dia, no grupo submetido à cirurgia cardíaca, no período de março de 2004 a fevereiro de 2005. O conhecimento da fisiopatologia e dos fatores de risco associados à pneumonia permite o direcionamento de medidas visando a redução desses índices. O objetivo deste estudo foi avaliar o efeito da higiene oral com solução de clorexidina a $0,12 \%$ na incidência de pneumonia hospitalar e PAV nas crianças submetidas à cirurgia cardíaca. Foi realizado estudo de intervenção, prospectivo, com alocação aleatória de pacientes, controlado com placebo e duplo-cego, com 160 pacientes, no período de fevereiro de 2006 a fevereiro de 2008. Foram coletados dados demográficos e clínicos, e calculadas a incidência de pneumonia hospitalar e PAV. A análise estatística dos dados foi feita utilizando-se o programa SPSS 13.0. As variáveis contínuas foram comparadas pelo teste U de Mann- Whitney e as variáveis categóricas, pelo teste do Chi quadrado, com $\mathrm{p}<0,05$ significativo. A análise dos dados demográficos demonstrou que os grupos eram homogêneos, quanto à distribuição do peso, idade, sexo e escores de gravidade. Não foi observada diferença entre o tempo de internação pré-cirúrgica 
entre os grupos $(\mathrm{p}=0,63)$. Não houve diferença estatística quanto ao tempo de cirurgia, de anestesia, de circulação extracorpórea (CEC) e de parada anóxica nos dois grupos. A incidência de pneumonia hospitalar foi de $29,8 \%$ no grupo clorexidina e 24,6\% no grupo placebo ( $\mathrm{p}=0,46$ ), e a incidência de PA V foi de 18,3\% no grupo estudo e $15 \%$ no grupo controle $(\mathrm{p}=0,57)$. Não houve diferença quanto ao tempo de intubação e quanto à necessidade de reintubação $(\mathrm{p}=0,34: \mathrm{e} p=0,37$, respectivamente) nos dois grupos. Não se observou diferença, também, quanto ao intervalo entre internação hospitalar e o diagnóstico de PNM, e o tempo entre cirurgia e diagnóstico de PNM entre os grupos ( $\mathrm{p}=0,63$ e 0,10, respectivamente). Não foi observada diferença quanto ao tempo de uso de antimicrobianos e de drogas vasoativas entre os grupos $(\mathrm{p}=0,77 \mathrm{e} 0,16$, respectivamente). Quanto ao tempo de internação no CTI-P, a mediana foi de 3 e 4 dias, nos grupos clorexidina e placebo, respectivamente $(\mathrm{p}=0,53)$. Também não houve diferença quanto ao tempo de internação hospitalar, com mediana de 12 e 11 dias para os grupos estudo e controle, respectivamente $(\mathrm{p}=0,67)$. A análise da mortalidade de 28 dias entre os grupos também não evidenciou diferença estatística entre eles, sendo 5,7\% no grupo clorexidina e 6,8\% no grupo placebo (p=0,77). Em conclusão, no presente estudo, o uso da higiene oral com solução de clorexidina a $0,12 \%$ não se mostrou eficaz na redução da incidência de pneumonia nosocomial em crianças submetidas à cirurgia cardíaca.

\title{
INDICADORES ANTROPOMÉTRICOS DE SOBREPESO E OBESIDADE NA IDADE ESCOLAR: PREVALÊNCIA E ASSOCIAÇÕES
}

\author{
Denise Nascimento Mesquita \\ Orientador: Prof. Dr. Marco Antonio Barbieri \\ Dissertação de Mestrado apresentada em 16/02/2009
}

A obesidade na inrancia e adolescência tem sido apontada como um dos maiores problemas de saúde pública em vários países, ocorrendo este aumento mundialmente. Além disso, tem sido observado o acúmulo de gordura na região abdominal refletindo o aumento de gordura subcutânea e visceral em indivíduos obesos. O objetivo deste estudo foi conhecer a prevalência de sobrepeso e obesidade em crianças brasileiras, de 7 a 11 anos de idade, em cidades de diferentes características socioeconômicas e também verificar o aumento de gordura corporal por meio da medida de circunferência de cintura (CC). Métodos: Foram avaliadas as, medidas de peso, altura e circunferência de cintura de 1683 crianças na idade escolar, usando-se técnicas padronizadas. Sobrepeso e obesidade foram classificados segundo os critérios propostos pelo CDC, 2000 e a circunferência de cintura pelo CDC, 2005. As infonnações socioeconômicas foram obtidas por meio questionários. Resultados: Foram encontrados $13,4 \%$ e 12,5\% de sobrepeso e obesidade, respectivamente, em Ribeirão Preto. Já em São Luís, observou-se menos crianças com sobrepeso e obesas do que o esperado, e alta prevalência de subnutrição (18,5\%). A população de São Luís também se mostrou mais baixa e com menores valores de circunferência de cintura do que em Ribeirão Preto. Em relação à adiposidade abdominal, crianças que estavam acima do P90 para a CC, tiveram seu IMC classificado de acima do P95. Quando foram correlacionadas as três variáveis (IMC, CC e altura), houve forte correlação entre IMC e CC para o sexo masculino e feminino ( $\mathrm{r}=0,92$ vs r = 0,89) em Ribeirão Preto, ocorrendo o mesmo para São Luís ( $\mathrm{r}=0,88$ vs $\mathrm{r}=0,83$ ), e uma moderada correlação da altura com a CC. Os fatores socioeconômicos associados ao sobrepeso e obesidade em Ribeirão Preto foram: ser do sexo feminino e a menor quantidade de pessoas vivendo no mesmo domicílio; em São Luís além deste manual qualificado. A CC mostrou pouca associação com fatores socioeconômicos e uma forte correlação com IMC, embora nem sempre concordantes. Conclusão: A prevalência de obesidade e sobrepeso encontrada se mostrou elevada em Ribeirão Preto, notou-se em contrapartida, que em São Luís ainda prevalece a subnutrição, contrastando estas duas populações. Ressalta-se, que a CC é uma boa medida para investigar adiposidade abdominal, sendo concordante com os valores elevados de IMC.

\section{ESTUDO FUNCIONAL DAS MUTAÇÕES P.R947X E P.L848P E ESTUDO DE EFEITO FUNDADOR DA MUTAÇÃO P.R947X NO GENE DO RECEPTOR DO MINERALOCORTICÓIDE}

\section{Fábio Luiz Fernandes Rosa}

Orientador: Prof. Dr. Sonir Roberto Rauber Antonini

Tese de Doutorado apresentada em 18/02/2009

A forma renal do pseudohipoaldosteronismo tipo 1 (PHA 1) caracteriza-se por perda de sal no período neonatal secundária a uma resistência renal à ação dos mineralocorticóides. A forma renal do PHA 1 ocorre por mutações inativadoras no gene do receptor do mineralocorticóide (MR). No presente estudo avaliamos a possibilidade de ancestralidade (efeito fundador) para a mutação MR p.R947X em famílias turcas e uma família brasileira com PHA1. A análise de marcadores 
flanqueando o gene do MR mostrou diferentes haplótipos segregando com a mutação em cada família. Excluímos, portanto, a possibilidade de efeito fundador desta mutação, caracterizando o primeiro hot spot mutacional no gene do MR. Avaliamos, também, se os polimorfismos MR c.-2G>C, $\alpha$ ENaC p.C618F e $\beta E N a C$ p.G442V poderiam influenciar os diferentes fenótipos obserados nos indivíduos brasileiros portadores da mutação MR p.R947X. Todos os indivíduos estudados foram homozigotos para os alelos mais frequentes destes polimorfismos, descartando-se a participação destes polimorfismos na variabilidade fenotípica destes indivíduos. Realizamos o estudo funcional das mutações MR p.R947X e da mutação MR p.L848P, encontrada em outra família com PHA1. A análise transcricional, realizada em culturas de células RCSV3 transfectadas com o MR nativo ou com os receptores mutantes evidenciou a ausência de atividade transcricional induzida pela aldosterona para a mutação p. R947X e transativação significativamente reduzida do receptor mutante MR P848. Adicionalmente, estudamos a expressão de genes responsivos à aldosterona (SGK1, SCNN1A e GILZ), em células HK transfectadas com os MR nativo e os mutantes MR X947 e MR P848. Nas células transfectadas com os receptores mutantes, o padrão de expressão destes genes foi diferente do padrão observado com o MR nativo, não tendo sido observado incremento significativo da expressão gênica com os receptor a atividade transcricional reduzida observada nos receptores mutantes MR X947 e MR P848, comprova a participação destas mutações no fenótipo do PHA1.

\section{ANÁLISE VETORIAL DE IMPEDÂNCIA BIOELÉTRICA E ÂNGULO DE FASE DE RECÉM-NASCIDOS A TERMO, ADEQUADOS PARA A IDADE GESTACIONAL}

\section{Ana Vitoria Barban Margutti}

Orientador: Prof. Dr. José Simon Camelo Júnior

Dissertação de Mestrado apresentada em 05/03/2009

Devido às dificuldades encontradas no período neonatal e excessiva variabilidade da quantidade de água no organismo do recém-nascido, considera-se a análise vetorial da impedância bioelétrica (BIVA) um método propício para avaliação da composição corporal. Trata-se de um método que não faz nenhuma pré-suposição sobre valores da composição corporal, podendo ser controlado por seus próprios valores, sem necessidade de validação com padrões-ouro, independente de equações ou modelos. Os objetivos do estudo foram estabelecer valores de referência, criar curvas de BIVA e estabelecer valores de normalidade de ângulo de fase em recém- nascidos a termo, sadios e adequados para a idade gestacional de 7 a 28 dias de vida, além de comparar os dados de BIVA entre os sexos e entre os existentes na literatura para neonatos na primeira semana de vida e lactentes jovens, com os dos obtidos neste estudo. Este estudo descritivo transversal avaliou recém-nascidos saudáveis de uma maternidade pública de Ribeirão Preto -SP -Brasil. Foram coletados dados neonatais, antropométricos e impedância bioelétrica (aparelho de monofrequência RJL System ® model Quantum II - $800 \mu \mathrm{A}$ e $50 \mathrm{kHz}$ ). Usando distribuição bivariável normal de $\mathrm{R} / \mathrm{H}$ e Xc/H (resistência e reactância por comprimento do neonato, respectivamente), foi calculado e assim confeccionados os gráficos RXc com os intervalos de tolerância de 95,75 e $50 \%$ do valor vetorial da impedância através do BIVA Software 2002 (PICCOLI; PASTORI, 2002). Foram avaliados 109 neonatos (52,3\% do sexo feminino), nascidos a termo, adequados para idade gestacional e em aleitamento materno exclusivo. Aidade média foi $13( \pm 3,6)$ dias. O peso médio encontrado foi $3545 \mathrm{~g}$, sendo maior no sexo masculino ( $\mathrm{p}=0,0469)$. Quanto ao comprimento corporal, a média foi $51 \mathrm{~cm}$, não havendo diferença entre os sexos $(\mathrm{p}>0,05)$. As médias de R $( \pm \mathrm{DP})$ foram 684,8 $( \pm 53,5) ; 673,4( \pm 37,6)$ e 695,2 foram 37,5 ( $\pm 5,3)$; 36,7 ( $\pm 4,9)$ e 38,3 $( \pm 5,6)$ 'ômega', respectivamente para todos os neonatos, e separados por sexo (meninos e meninas), havendo diferença estatisticamente significativa (p<0,05). Em relação ao ângulo de fase, encontramos valor de normalidade de $3,14^{\circ} \pm 0,430^{\circ}$ para todos os neonatos, $3,12^{\circ} \pm 0,39^{\circ}$ para os do sexo masculino e $3,17^{\circ} \pm 0,48^{\circ}$ para os do sexo feminino, não havendo diferença estatisticamente significativa $(\mathrm{p}=0,5747)$. Para a análise vetorial de recém-nascidos de 7 a 28 dias de vida, devem ser utilizados os valores de referência específicos para esta faixa etária e sexo, pois estes se apresentaram diferentes dos descritos na literatura. Com o modelo de estudo BIVA, torna-se possível a comparação direta do vetor medido na criança pequena ou com necessidade de cuidados especiais com os intervalos de tolerância de referência de neonatos saudáveis, permitindo uma avaliação qualitativa da composição corporal sem o conhecimento do peso corporal e sem erro de predição das fórmulas. Com os valores de ângulo de fase caracterizados no presente estudo para recém-nascidos brasileiros saudáveis, de 7 a 28 dias de vida, dados de pacientes críticos podem ser comparados, sendo útil durante a internação e acompanhamento de pacientes graves. 


\title{
GRAVIDEZ NA ADOLESCÊNCIA E FATORES DE RISCO PARA O BAIXO PESO AO NASCER E PREMATURIDADE
}

\author{
Alzira Maria D’Avila Nery Guimarães \\ Orientador: Prof. Dr. Marco Antônio Barbieri \\ Tese de Doutorado apresentada em 06/03/2009
}

Foi realizado um estudo transversal objetivando estudar as principais características das mães de uma coorte de nascimento, de parto único, hospitalar, com especial atenção às mães adolescentes e identificar os fatores de risco para o baixo peso ao nascer -BPN e prematuridade. Foram entrevistadas 4746 mulheres residentes na Região Metropolitana (Grande Aracaju), no período de 08/03 à 15/07/05, ocasião em que também foram aferidas medidas vitais em seus conceptos. Foi verificado que as mães adolescentes tiveram resultados perinatais mais desfavoráveis quando comparadas com os outros grupos de mães investigadas. Observou-se que as características não se distribuíam uniformemente em todas as adolescentes, visto que o grupo de adolescentes $<18$ anos apresentou resultados mais adversos, quando comparados com as adolescentes mais velhas. A duração da gestação foi o fator de risco mais forte para o BPN, a cada semana a mais de gestação, a chance da criança nascer com BPN cai pela metade, RC: 0,53 (IC: 0,49 -0,56). Os outros fatores de risco foram: adequação do pré-natal - não fez pré-natal, 2,35 (IC: 1,10 -5,05) e tabagismo na gestação, RC: 2,04 (IC: 1,28 - 3,25). Houve interação da idade materna com situação conjugal, ou seja, mães adolescentes < 18 anos e 18 a 19 anos), sem companheiros, tiveram mais chance de ter filhos de baixo peso (RC: 3,11; IC: 2,00- 4,84; e RC: 1,95; IC: 1,22 -3,12 respectivamente), mostrando que a idade materna $<20$ anos) está vinculada à situação conjugal para o risco de BPN. Para a prematuridade, foram identificados os seguintes fatores de risco: idade materna < 18 anos, RC: 1,73 (IC: 1,24 -2,42), adequação do pré-natal -não fez pré-natal, RC: 2,14; (IC: 1,15 -4,01), situação conjugal 2,47 (IC: 1,94 - 1,69) e uso de bebidas alcoólicas na gestação, RC: 1,31 (IC: 1,01 -1,69). Fatores de risco psicossociais, comportamentais e biológicos estiveram associados ao baixo peso prematuridade. Este estudo fornece subsídios para o estabelecimento de estratégias específicas e políticas públicas de saúde direcionadas à melhoria dos indicadores de saúde materno e infantil.

\section{RELAÇÕES ENTRE AS MEDIDAS DA COMPOSIÇÃO CORPORAL DE ADOLESCENTES OBESOS FORNECIDAS PELO MÉTODO DA DILUIÇÃO DE ÓXIDO DE DEUTÉRIO E PELA IMPEDÂNCIA BIOELÉTRICA}

\author{
Cristina Maria Mendes Resende \\ Orientadora: Prof $^{\mathrm{a}}$. Dr ${ }^{\mathrm{a}}$. Jacqueline Pontes Monteiro \\ Dissertação de Mestrado apresentada em 09/03/2009
}

Introdução: O Índice de Massa Corporal, critério atualmente utilizado para diagnosticar a obesidade em adolescentes, não avalia a gordura corporal total. Para um melhor acompanhamento desses pacientes, é de grande importância uma avaliação da composição corporal, e a impedância bioelétrica (BIA) é um método simples, rápido e capaz de fazer esta avaliação. Porém levando-se em conta que pacientes obesos apresentam uma alteração na quantidade de água corporal, de massa corporal gorda e magra surge a necessidade de ajuste de fórmulas específicas por meio de um método referência para estes pacientes, principalmente em adolescentes que estão em processo de crescimento e desenvolvimento. Objetivo: $\mathrm{O}$ objetivo deste estudo foi avaliar as relações entre as medidas da composição corporal de adolescentes obesos fornecidas pela BIA e pelo método da diluição de óxido de deutério. Metodologia: Foram estudados 40 adolescentes obesos, com idade entre 10 e 13 anos. Estes foram avaliados pela antropometria e composição corporal segundo a impedância bioelétrica multifrequência e o método de óxido de deutério. Resultados: A comparação de médias para as seguintes variáveis: massa corporal gorda $(\mathrm{kg})$, massa corporal magra $(\mathrm{kg})$ e porcentagem de água corporal, determinada pelo método da diluição de óxido de deutério e pela BIA apresentou diferenças significativas. A BIA superestimou os valores de massa corporal magra $(\mathrm{kg})$ e percentual de água corporal total e subestimou os valores de massa corporal gorda $(\mathrm{kg})$. Os resultados obtidos pela BIA, quando comparados com os dados do método da diluição de óxido de deutério, apresentaram uma alta correlação em relação às variáveis: massa corporal magra $(\mathrm{r}=0,89 ; \mathrm{p}<0,0001)$ e massa corporal gorda $(\mathrm{r}=0,92 ; \mathrm{p}<0,0001)$. Em relação à porcentagem de água corporal total, encontramos uma média correlação $(\mathrm{r}=0,59 ; \mathrm{p}<0,0001)$. Os modelos de regressão linear corporal magra $(\mathrm{kg})$, massa corporal gorda $(\mathrm{kg})$ e percentual de água corporal total, foram bem ajustados. Os valores preditos pelo modelo aproximam-se bem dos valores reais observados pelo método da diluição de óxido de deutério: Massa corporal magra obtida pelo método da diluição de óxido de deutério $=0,842 \mathrm{x}$ massa corporal 
magra obtida pela impedância bioelétrica multifrequência. Massa corporal gorda obtida pelo método da diluição de óxido de deutério $=0,855 \mathrm{x}$ massa corporal gorda obtida pela impedância bioelétrica multifrequência $+0,152 \times \mathrm{x}$ peso $(\mathrm{kg})$. Porcentagem de água corporal total obtida pelo método da diluição de óxido de deutério $=0,813$ x porcentagem de água corporal total obtida pela impedância bioelétrica multifrequência.Conclusão: As medidas de composição corporal obtidas pela BIA são estatisticamente diferentes das medidas obtidas pelo método de diluição de óxido de deutério, apesar disso, existe uma correlação positiva forte entre as variáveis de composição corporal, analisadas pelo método da diluição de óxido de deutério e pela BIA em relação à massa corporal magra e à massa corporal gorda. Em relação à porcentagem de água corporal total, a correlação foi classificada como sendo positiva e moderada. É possível predizer resultados (medidas) da composição corporal determinados pelo método da diluição de óxido de deutério de adolescentes obesos, utilizando as medidas fornecidas pela BIA por meio de uma equação de regressão com, no máximo, duas variáveis.

\title{
PAPEL DA ATIVAÇÃO DO FATOR NUCLEAR KAPPA-B NA DISFUNÇÃO MIOCÁRDICA DO CHOQUE SÉPTICO PEDIÁTRICO
}

\section{Fábio Carmona}

Orientadora: Prof ${ }^{a}$. Dr ${ }^{\mathrm{a}}$. Ana Paula de Carvalho Panzeri Carlotti

Tese de Doutorado apresentada em 30/03/2009

Crianças com choque séptico apresentam elevada morbi-mortalidade. A disfunção miocárdica é uma complicação freqüente e caracteriza-se por redução da fração de ejeção (FE) e aumento do volume diastólico final do ventrículo esquerdo (VDFVE). O papel da reação inflamatória sistêmica (SRIS) na gênese da disfunção miocárdica que ocorre nesses pacientes ainda não está completamente esclarecido. A SRIS é regulada pela atividade do fator nuclear kappa-B (NF-кB), que pode ser

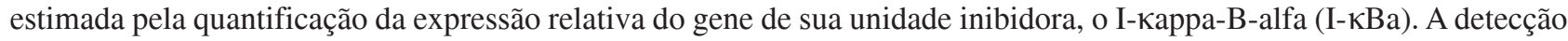
precoce da disfunção miocárdica na população pediátrica é difícil na prática clínica. Nós estudamos uma coorte de 15 pacientes pediátricos internados na Unidade de Terapia Intensiva Pediátrica (UTIP) de um hospital terciário, com idade mediana de 62 meses (variando de 2 a 215 meses) com diagnóstico de choque séptico. Foram coletados dados clínicos e amostras de sangue diárias, e realizada ecocardiografia. As amostras de sangue foram analisadas para determinação da expressão relativa do gene do I- $\kappa$ Ba por reação da polimerase em cadeia quantitativa em tempo real (RQ-PCR), e determinação das concentrações plasmáticas do peptídeo natriurético tipo B (BNP) e da troponina I cardíaca (cTnI). Os pacientes foram divididos em 2 grupos de acordo com a FE menor (grupo 1) e maior ou igual a 50\% (grupo 2). Nossos resultados

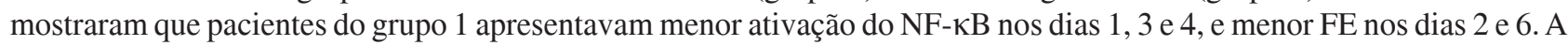
ativação do NF- $\kappa$ B correlacionou-se positivamente com maior VDFVE. Dentre os pacientes com expressão relativa do gene do I- $\mathrm{KBa}$ acima da mediana no $1^{\circ}$ dia observou-se maior proporção de indivíduos com FE maior ou igual a 50\%. As concentrações de cTnI e BNP correlacionaram-se positivamente entre si, mas não com parâmetros clínicos ou ecocardiográficos de disfunção miocárdica. Em conclusão, em pacientes pediátricos com choque séptico a maior ativação do NF- $\mathrm{BB}$ associou-se a melhores índices ecocardiográficos de disfunção miocárdica, o que poderia sugerir um papel daquele na ativação de mecanismos compensatórios cardíacos à injúria. BNP e cTnI não foram bons marcadores de disfunção miocárdica nessa população específica.

\section{Saúde Mental}

\section{CUIDADOS PRIMÁRIOS À SAÚDE MENTAL: DEPRESSÃO MATERNA E ASPECTOS COMPORTAMENTAIS DE CRIANÇAS EM IDADE ESCOLAR}

\author{
Ana Vilela Mendes \\ Orientadora: Prof $^{\mathrm{a}}$. Dr ${ }^{\mathrm{a}}$. Sonia Regina Loureiro \\ Dissertação de Mestrado apresentada em 10/02/2009
}

Os transtornos mentais têm sido considerados problemas relevantes para a população mundial. Dentre estes, as síndromes depressivas, especialmente em mulheres/mães, tem sido reconhecidas como um problema de saúde pública, 
sendo associadas ao comprometimento do desenvolvimento infantil. Objetiva-se: caracterizar os indicadores comportamentais apresentados por crianças em idade escolar que convivem com mães com depressão, identificadas em um serviço de atenção primária, comparando tal perfil com o de crianças que convivem com mães sem história psiquiátrica; e caracterizar e comparar o perfil demográfico e clínico apresentado pelas mulheres-mães. A identificação das mulheres foi feita quando procuraram ou foram encaminhadas para serviços médicos, não psiquiátricos, em uma Unidade Básica de Saúde da cidade de Uberaba-MG. Das 680 mulheres agendadas no período do estudo, $205(30,1 \%)$ apresentavam o perfil definido para a inclusão: mulheres/ mães, não grávidas, com filhos biológicos em idade escolar, sem deficiências físicas e/ou sensoriais aparentes. De forma ativa todas foram convidadas a participarem do estudo, 185 aceitaram. A identificação das mães com indicadores de depressão foi realizada por meio do Questionário sobre a Saúde do Paciente-9 (PHQ-9) e a confirmação diagnóstica realizada por meio da Entrevista Clínica Estruturada para o DSM-IV (SCID). Foram excluídas do estudo oito mulheres que apresentavam diagnóstico de outros transtornos psiquiátricos e/ou comorbidades orgânicas. Participaram do estudo 177 mães e respectivos filhos, de ambos os sexos, com idade entre seis e 12 anos. Procedeu-se com as mães a aplicação do Questionário de Capacidades e Dificuldades (SDQ) relativo ao comportamento das crianças. Os dados foram codificados segundo as recomendações técnicas e analisados por procedimentos estatísticos. As crianças, com base nas avaliações, foram distribuídas em dois grupos, a saber: Grupo 1 (G1): 60 crianças cujas mães apresentaram diagnóstico de depressão, e Grupo 2 (G2): 117 crianças cujas mães não apresentaram diagnóstico de depressão e de outros distúrbios psiquiátricos. Quanto aos indicadores de problemas comportamentais, em todas as subescalas do SDQ, o G1 apresentou maiores porcentagens de crianças com problemas quando comparadas ao G2. Verificou-se que a depressão materna por si só foi preditora de problemas comportamentais para as crianças de G1, visto que todas as variáveis demográficas relativas às mães e crianças não apresentaram diferenças significativas quando das comparações intra grupo. No G2, os problemas comportamentais foram mais relatados pelas mães de baixa escolaridade $(72,7 \%)$.

As crianças do G1 apresentaram 2,8 vezes mais de chance de terem problemas comportamentais quando comparadas às do G2. Das cinco subescalas do SDQ avaliadas, ao se comparar os grupos, apenas na escala de problemas de conduta observou-se valor com significância estatística, verificando-se que as crianças de G1 apresentaram 1,9 vezes mais de chances de problemas de conduta, quando comparadas ao G2. Constatou-se assim que a convivência com a depressão materna mostrou-se associada à presença de problemas comportamentais e problemas de conduta. Destaca-se a necessidade, no contexto de atenção primária à saúde, da implantação de protocolos de avaliação que visem à identificação precoce de indicadores de saúde mental infantil e materna como forma de instrumentar práticas preventivas.

\title{
USO DE ÁLCOOL NA GESTAÇÃO E SUA RELAÇÃO COM SINTOMAS DEPRESSIVOS NO PÓS-PARTO
}

\author{
Poliana Patrício Aliane \\ Orentador: Prof. Dr. Erikson Felipe Furtado \\ Dissertação de Mestrado apresentada em 11/02/2009
}

O consumo de álcool durante a gestação tem sido associado na literatura científica a uma maior intensidade de sofrimento psiquiátrico durante a gestação e no pós-parto. Este estudo teve como objetivo principal verificar se o consumo de álcool em gestantes está relacionado a um aumento de sintomas depressivos e/ou ao diagnóstico de depressão no pós-parto. Para tal foi realizado um estudo prospectivo, com dois tempos de coleta de dados. Foram convidadas a participar gestantes da rede pública de saúde da cidade de Juiz de Fora/MG. Inicialmente foram entrevistadas 260 mulheres no terceiro trimestre gestacional, das quais 177 foram entrevistadas entre 15 dias a 3 meses após o parto. Para avaliação do uso de álcool durante a gestação foram utilizados os instrumentos T-ACE (Tolerance, Annoyed, Cut down, Eyeopener) e AUDIT C (Alcohol Use Disorders Identification Test C), além do relato das gestantes sobre a quantidade de álcool ingerida durante toda a gestação. Para avaliação de sintomas depressivos no pós-parto foi utilizado o instrumento EPDS (Edinburgh Postnatal Depression Scale) e para o diagnóstico de Episódio Depressivo Maior foi utilizada a entrevista diagnóstica MINI (Mini International Neuropsychiatric Interview). Os resultados obtidos apontaram para um aumento de sintomas depressivos no pós-parto proporcional ao aumento do consumo de álcool durante a gestação medido pelo total do AUDIT C (Spearman Correlation, $\mathrm{r}=0,251 ; \mathrm{p}<0,001)$ e pelo total em gramas de álcool consumido durante toda a gestação (Spearman Correlation, r=0,185; p=0,01). Além disso, foi observado uma maior prevalência de depressão pósparto entre as mulheres que tiveram pelo menos um binge alcoólico durante a gestação (Non-parametric Chi-Square, value $=88,28, \mathrm{p}<0,001)$. Os dados apresentados permitem concluir que existe um aumento de sintomatologia depressiva no pós-parto à medida que aumenta o consumo de álcool na gestação e aumento de diagnóstico para aquelas que tiveram pelo menos um binge alcoólico durante a gestação. 


\title{
DETECÇÃO DE RISCO PARA PROBLEMAS NO DESENVOLVIMENTO DE BEBÊS NASCIDOS PRÉ-TERMO NO PRIMEIRO ANO
}

\author{
Cibelle Kayenne Martins Roberto Formiga
}

Orientadora: Prof ${ }^{a}$. Dr ${ }^{a}$. Maria Beatriz Martins Linhares

Tese de Doutorado apresentada em 31/03/2009

Diversos fatores de risco biológicos e ambientais estão envolvidos na trajetória de desenvolvimento de bebês prétermo. O presente estudo teve por objetivos avaliar os indicadores de risco ou atraso para problemas no desenvolvimento de bebês nascidos pré-termo e baixo peso, focalizando o desenvolvimento neurocomportamental na fase neonatal, desenvolvimento pessoal-social, linguagem e motor nos oito primeiros meses de idade pós-natal; identificar o melhor modelo de predição para os indicadores de risco ou atraso na trajetória de desenvolvimento dos bebês, baseado nas variáveis biológicas e socioeconômicas; analisar a trajetória de desenvolvimento dos bebês nascidos pré-termo por meio do acompanhamento longitudinal desde o período neonatal até oito meses de idade cronológica corrigida (ICC); avaliar os parâmetros psicométricos de validade concorrente do Teste de Denver II e avaliação do desenvolvimento motor e validade preditiva do NAPI e Teste de Denver II. A amostra foi constituída por 190 bebês nascidos pré-termo com baixo peso ao nascimento, provenientes da UTIN do Hospital Materno Infantil em Goiânia (GO). Na avaliação utilizou-se os instrumentos Neurobehavioral Assessment of Preterm Infant (NAPI) na fase neonatal, Teste de Triagem do Desenvolvimento de Denver II entre 2 e 8 meses de ICC, Test of Infant MotorPerformance (TIMP) entre 2 e 4 meses de ICC, Alberta Infant Motor Scale (AIMS), entre 4 e 8 meses de ICC. O procedimento de coleta envolveu visitas à unidade neonatal de médio risco para avaliação dos bebês na fase neonatal ainda no período de internação hospitalar e avaliações subsequentes de seguimento no Ambulatório de Alto Risco do referido Hospital. Os dados de caracterização das crianças foram analisados por meio de estatística descritiva. Na análise de comparação entre grupos foram utilizados os testes Qui-quadrado e t de Student. Na análise de predição foram realizados testes de regressão logística. Em todas as análises realizadas foi adotado o nível de significância de 5\%. Os resultados demonstraram que $31 \%$ dos bebês apresentaram atrasos no desenvolvimento neurocomportamental na fase neonatal. Em relação ao desenvolvimento global avaliado pelo teste de Denver II, 51\% revelou risco para problemas entre 2 e 4 meses de ICC, $43 \%$ entre 4 e 6 meses de ICC e $33 \%$ entre 6 e 8 meses de ICC Quanto ao desenvolvimento motor, $48 \%$ dos bebês apresentaram atraso entre 2 e 4 meses de ICC, $47 \%$ entre 4 e 6 meses de ICC e $36 \%$ entre 6 e 8 meses de ICC. Ao comparar o desempenho dos bebês nas idades cronológica e corrigida, verificou-se a necessidade de realizar a correção da idade em todas as faixas etárias avaliadas. Verificou-se que fatores de risco tais como: peso $<1.500 \mathrm{~g}$, idade gestacional £ 32 semanas, alto risco clínico neonatal, presença de hemorragias intracranianas, aleitamento materno artificial, baixa escolaridade do chefe da família, maior densidade de pessoas na residência, número reduzido de cômodos na casa e nível sócio-econômico baixo foram as principais variáveis de maior influência no risco e atraso no desenvolvimento. Os bebês acompanhando longitudinalmente apresentaram $24 \%$ de atraso na avaliação neurocomportamental na fase neonatal e manutenção da taxa de risco no desenvolvimento global e atraso no desenvolvimento motor entre 2 e 8 meses de ICC. Quanto ao estudo da validade concorrente, verificou-se que o Teste de Denver II apresentou concordância de 64\% com o teste TIMP entre 2 e 4 meses de ICC, $89 \%$ com a escala AIMS entre 4 e 6 meses de ICC e $82 \%$ com a escala AIMS entre 6 e 8 meses de ICC. Em relação a validade preditiva, verificou-se que a avaliação NAPI apresentou associações com o desenvolvimento motor e global e o teste de Denver apresentou concordância ${ }^{3} 52 \%$ nas faixas etárias avaliadas pela AIMS.

\section{Saúde na Comunidade}

\section{COMPREENSÃO DA PRÁTICA MÉDICA NA PERSPECTIVA DE USUÁRIOS DO PROGRAMA DE SAÚDE DA FAMÍLIA RURAL DE SACRAMENTO/MG}

\author{
Haroldo da Silva Santana \\ Orientador: Prof. Dr. Antonio Ruffino Netto \\ Dissertação de Mestrado apresentada em 05/01/2009
}

Estudo de abordagem qualitativa realizado junto aos usuários de famílias adscritas a uma equipe rural do Programa de Saúde da Família (PSF) de Sacramento/MG que teve por objetivo compreender a prática médica a partir da identificação de crenças e representações daquelas famílias. A compreensão da prática médica é balizada através da vinculação da 
medicina com os componentes políticos e ideológicos que se moldam em seu entorno. Pressuposto é que a prática médica não é neutra mesmo que seus agentes não tenham disso consciência. A medicina, e seu exercício, a prática médica, conformam um dos processos de reprodução da sociedade que torna os cidadãos socialmente desiguais. Trabalhamos com a técnica do grupo focal e utilizamos a análise temática com a identificação de três categorias: Disponibilidade, Legitimidade e Contexto Geral do Trabalho Médico. Esses temas trazem questões interligadas, mas que não se superpõem exatamente umas às outras conquanto constituam indagações específicas e cuja compreensão requer considerá-las separadamente. Destacamos com relevância a amplitude dos temas retratados nas crenças e representações daquela população habilitando-o como um interlocutor privilegiado ao tratar-se dessa temática.

\title{
INFLUÊNCIA DA RESTRIÇÃO DE CRESCIMENTO INTRA-UTERINO NA IDADE DA MENARCA: ESTUDO DA COORTE DE NASCIDOS VIVOS DE RIBEIRÃO PRETO DE 1978/9
}

\author{
Francine Leite \\ Orientadora: Profa. Dra.Maria da Conceição Pereira Saraiva \\ Dissertação de Mestrado apresentada em 08/01/2009
}

A idade da menarca é um marco da puberdade e, quando antecipada, parece estar associada a um maior risco de desenvolvimento de câncer de mama, síndrome metabólica e obesidade. É possível que alterações no ambiente intrauterino, como a restrição de crescimento do feto, levem a interferências no sistema hipotálamo-hipófise-gonadal resultando em alterações na idade da menarca. Em vista da controvérsia dos fatores que influenciam na idade da menarca, este estudo testou a hipótese da associação entre restrição de crescimento intra-uterino (baixo peso ao nascer, pequeno para idade gestacional, restrição intra-uterina de Kramer) e antecipação da idade da menarca. Em uma sub-amostra foi testada a possível interação entre a restrição de crescimento intra-uterino e o índice de massa corpórea. Para esse estudo foram utilizadas informações coletadas nos seguimentos de 1987/9 e 2004/5 de 1056 meninas nascidas em Ribeirão Preto, provenientes do estudo de coorte dos nascidos vivos em Ribeirão Preto de 1978/9. Menarca antecipada foi definida como primeiro sangramento vaginal ocorrido antes dos 12 anos de idade. Análise univariada foi seguida de análise bivariada e multivariada por meio de modelo generalizado empregando distribuição de Poisson para estimativa de riscos relativos e erro padrão por meio de método robusto. Os fatores de confusão controlados foram idade, escolaridade e situação conjugal da mãe, número de irmãos, comprimento ao nascer, prematuridade e índice de massa corpórea (apenas para a sub-amostra). Em média, a menarca ocorreu aos 12,3 anos ( $\mathrm{DP}=1,5)$. A ocorrência de menarca antecipada foi de 27,7\% $(\mathrm{n}=293)$ para a coorte inteira e de 29,1\% (n= 172) na sub-amostra. Foi encontrada associação negativa entre restrição de crescimento intra-uterino, seja representado por baixo peso ao nascer (Risco Relativo, RR=0,47; Intervalo de Confiança de 95\%, IC95\%: 0,26-0,84), pequeno para idade gestacional $(\mathrm{RR}=0,57 ; \mathrm{IC} 95 \%: 0,37-0,89)$ ou restrição de Kramer ( $\mathrm{RR}=0,65 ; \mathrm{IC} 95 \%: 0,47-0,92)$, com a antecipação da idade da menarca. Os resultados foram semelhantes na análise da sub-amostra, porém sem significância estatística. Quando o índice de massa corpórea foi considerado na análise da sub-amostra, não houve modificação dos resultados. Desta forma, este estudo demonstrou associação negativa entre restrição de crescimento intra-uterino e antecipação da idade da menarca, ou seja, a restrição de crescimento foi fator de proteção da menarca antecipada.

\section{FATORES ASSOCIADOS AO AVC ENTRE IDOSOS DO MUNICÍPIO DE SÃO PAULO: RESULTADOS DO ESTUDO SABE}

\author{
Silvia Cristina Sawada \\ Orientador: Prof. Dr. Jair Licio Ferreira Santos \\ Dissertação de Mestrado apresentada em 29/01/2009
}

O envelhecimento é um fenômeno mundial resultado do declínio da fecundidade, podendo ser acelerado pelo declínio da mortalidade se este se concentrar nas idades mais avançadas. O idoso é definido pela Organização Mundial da Saúde como o indivíduo com 60 anos ou mais nos países em desenvolvimento como o Brasil.

O processo de transição epidemiológica em que se encontra o Brasil está determinado pelo progressivo aumento no número de idosos e, com isto, aumento das doenças crônico-degenerativas, entre elas, as doenças cerebrovasculares que são umas das grandes causadoras de sequelas com sérias implicações socioeconômicas; sendo importante o conhecimento de seus fatores associados para melhor controle e prevenção das consequências. 
Este trabalho tem como objetivo analisar os fatores de risco e as condições pregressas de acidente vascular cerebral (AVC) auto-referido na população idosa do município de São Paulo através dos dados coletados do Estudo Saúde, Bem-estar e Envelhecimento (SABE).

A amostra constou de 2.143 idosos, residentes no município de São Paulo, que participaram do Projeto SABE realizado de 2000 a 2001. As variáveis referentes aos possíveis fatores associados ao AVC e condições pregressas de saúde, foram selecionadas da base de dados do Estudo SABE com base na literatura e foram consideradas como variáveis independentes. O AVC referido foi considerado como variável dependente.

Para a apreciação das possíveis associações das variáveis independentes com a variável desfecho AVC foi empregada técnica multivariada. O elemento de avaliação do efeito escolhido é o Odds Ratio (OR).

Do grupo estudado, 58,6\% foram mulheres e 41,4\% homens. Cento e setenta idosos referiram ter tido AVC sendo 85 de cada sexo, com uma prevalência de $6 \%$ entre as mulheres e $9 \%$ entre os homens. Dentro das variáveis estudadas, os fatores de risco que aumentaram a chance de AVC em ambos os sexos foram: febre reumática (OR: 2,63 para homens e OR: 4,02 para mulheres) e saúde referida (OR: 1.95 para homens e OR: 3,08 para mulheres). Doença cardíaca (OR: 2,15), atividade física (OR: 3,47) e internação hospitalar (OR: 4,19) foram os fatores associados ao aumento de risco para AVC somente para o sexo masculino, enquanto que idade (OR: 1,03) e consultas médicas $(\mathrm{OR}: 3,42)$ foram para o sexo feminino. Como fatores de proteção foi encontrada a terapia de reposição hormonal nas mulheres com OR de 0, 32 e tabagismo nos homens com OR de 0,55 .

Os fatores associados ao risco de AVC referido são distintos entre os homens e mulheres. Nas mulheres idosas a idade, a realização de consultas médicas e má saúde referida são fatores de risco para AVC. No sexo masculino, a doença cardíaca, má saúde referida, internação hospitalar e referir atividade física são fatores associados a um maior risco de AVC. Como fator de proteção tivemos a terapia de reposição hormonal associado ao sexo feminino e tabagismo ao sexo masculino. A febre reumática foi a única condição pregressa relacionada a um significativo aumento de risco de AVC na velhice em ambos os sexos.

Por sua importância epidemiológica, as doenças cerebrovasculares necessitam de ações visando principalmente a prevenção primária desde a infância, evitando sua ocorrência e sequelas; mantendo o indivíduo saudável visando sua melhor qualidade de vida.

\section{ANÁLISE ESTATÍSTICA PARA DADOS DE CONTAGEM LONGITUDINAIS NA PRESENÇA DE COVARIAVEIS: APLICAÇÕES NA ÁREA MÉDICA}

\section{Emílio Augusto Coelho Barros}

Orientador: Prof. Dr. Jorge Alberto Achcar

Dissertação de Mestrado apresentada em 09/02/2009

Dados de contagem ao longo do tempo na presença de covariáveis são muito comuns em estudos na área da saúde coletiva, por exemplo; número de doenças que uma pessoa, com alguma característica especifica, adquiriu ao longo de um período de tempo; número de internações hospitalares em um período de tempo, devido a algum tipo de doença; número de doadores de órgãos em um período de tempo. Nesse trabalho são apresentados diferentes modelos estatísticos de "fragilidade" de Poisson para a análise estatística de dados de contagem longitudinais. Teoricamente, a distribuição de Poisson exige que a média seja igual à variância, quando isto não ocorre tem-se a presença de uma variabilidade extraPoisson. Os modelos estatísticos propostos nesta dissertação incorporam a variabilidade extra-Poisson e capturam uma possível correlação entre as contagens para o mesmo indivíduo. Para cada modelo foi feito uma análise Bayesiana Hierárquica considerando os métodos MCMC (Markov Chain Monte Carlo). Utilizando bancos de dados reais, cedidos por pesquisadores auxiliados pelo CEMEQ (Centro de Métodos Quantitativos, USP/FMRP), foram discutidos alguns aspectos de discriminação Bayesiana para a escolha do melhor modelo. Um exemplo de banco de dados reais, que se encaixa na área da saúde coletiva, é composto de um estudo prospectivo, aberto e randomizado, realizado em pacientes infectados pelo HIV que procuraram atendimento na Unidade Especial de Terapia de Doenças Infecciosas (UETDI) do Hospital das Clínicas da Faculdade de Medicina de Ribeirão Preto da Universidade de São Paulo (HCFMRP-USP). Os esquemas terapêuticos estudados consistiam em zidovudina e lamivudina, associadas ao efavirenz ou lopinavir. Entre setembro de 2004 e maio de 2006 foram avaliados 66 pacientes, sendo 43 deles incluídos no estudo. Destes, 39 participantes alcançaram a semana 24 de acompanhamento, enquanto 27 atingiram a semana 48. Os grupos de pacientes apresentavam características basais semelhantes, quanto à idade, sexo, mediana de CD4 e carga viral. O interesse desse experimento é estudar a contagem de CD4 considerando os dois esquemas terapêuticos (efavirenz e lopinavir). 


\title{
ESTATÍSTICA EM BIOEQUIVALÊNCIA: GARANTIA NA QUALIDADE DO MEDICAMENTO GENÉRICO
}

\author{
Roberto Molina de Souza \\ Orientador: Prof. Dr. Jorge Alberto Achcar \\ Dissertação de Mestrado apresentada em 16/02/2009
}

Como alternativa aos medicamentos de uso humano de grande circulação no mercado brasileiro foram regulamentados os medicamentos genéricos, conforme a Lei dos genéricos n 9787/99, que evidenciaram os estudos de bioequivalência e biodisponibilidade no Brasil com o objetivo de avaliar a bioequivalência das formulações genéricas, tomando-se como referência os medicamentos já existentes no mercado e com eficácia comprovada. Duas formulações de um mesmo medicamento são consideradas bioequivalentes se suas biodisponibilidades não apresentam evidências de diferenças significativas segundo limites clinicamente especificados, denominados limites de bioequivalência. Os estudos de bioequivalência são realizados mediante a administração de duas formulações, sendo que uma está em teste e a outra é a referência, em um número de voluntários previamente definidos, usando-se um planejamento experimental, na maioria das vezes do tipo crossover. Após a retirada de sucessivas amostras sanguíneas ou urinárias em tempos pré-determinados, estudam-se alguns parâmetros farmacocinéticos como área sob a curva de concentração, concentração máxima do fármaco e tempo em que a concentração máxima ocorre. Esta dissertação de mestrado introduz alguns conceitos básicos de bioequivalência para, logo em seguida, apresentar análises Bayesianas para medidas de bioequivalência tanto univariada como multivariada assumindo a distribuição normal multivariada para os dados e também a distribuição $t$ de Student multivariada. Uma aplicação a fim de exemplificar o que foi introduzido é apresentada e, para o conjunto de dados em estudo têm-se, por meio de critérios de seleção de modelos, evidências favoráveis a escolha dos modelos multivariados para a condução deste estudo de bioequivalência média.

\section{CONHECIMENTOS E PERCEPÇÕES DOS USUÁRIOS DA ESTRATÉGIA SAÚDE DA FAMÍLIA SOBRE A FISIOTERAPIA}

\author{
Sarah Tarcisia Rebelo Ferreira de Carvalho \\ Orientadora: Prof ${ }^{\mathrm{a}}$. Dra ${ }^{\mathrm{a}}$. Maria do Carmo G. G. Caccia-Bava \\ Dissertação de Mestrado apresentada em 20/02/2009
}

O Ministério da Saúde criou em 1994 o Programa Saúde da Família (PSF) visando à reorientação do modelo assistencial do Brasil e a valorização da atenção básica. A partir da Portaria 648/06, passa a ser denominado de Estratégia Saúde da Família (EsSF) sinalizando para sua concepção mais ampla, voltada para as especificidades loco-regionais, para o trabalho intersetorial e para a valorização dos saberes e práticas interdisciplinares. Nesse contexto, várias experiências exitosas foram registradas de incorporação do fisioterapeuta na Atenção Básica, permitindo a ampliação de seu campo de atuação, historicamente vinculado à reabilitação, para atuar também na promoção da saúde e prevenção de agravos. No entanto, o número insuficiente de profissionais na rede assistencial, as dificuldades estruturais e materiais, e o desconhecimento da população sobre a atuação do fisioterapeuta ainda limitam a sua atividade na atenção básica. Essa pesquisa objetivou investigar o conhecimento dos usuários de uma Unidade Saúde da Família (USF) sobre a Fisioterapia, e sua percepção quanto às suas necessidades em relação à atuação do fisioterapeuta. Trata-se de um estudo transversal e descritivo, de abordagem quantitativa. Valeu-se da aplicação de um questionário elaborado pela autora a 275 usuários de uma USF em Ribeirão Preto/SP. Os entrevistados tinham como características predominantes a média de idade de 43 anos, ser do sexo feminino, morar com seus companheiros e residir na área adstrita à Unidade por cerca de 6 a 10 anos, trabalhar no próprio lar, apresentar baixa escolaridade, pertencer às classes econômicas $\mathrm{C}$ e D. Em relação à presença de familiares portadores de deficiência física ou doenças graves, tinham índice igual ou superior ao estimado pela OMS. Quanto aos aspectos mais específicos da Fisioterapia, embora a maioria já tivesse ouvido falar sobre a profissão e a considerasse muito importante, gostaria de saber mais sobre ela. Entretanto, o conhecimento dos entrevistados se mostrou voltado aos aspectos de reabilitação e/ou tratamento, indicaram que as pessoas que mais precisam de Fisioterapia são os deficientes físicos, portadores de lesão e/ou algias músculo-esquelético; que o fisioterapeuta trabalha principalmente no hospital; que não realiza ações educativas e que há dificuldade de acesso ao fisioterapeuta. Assim, $98 \%$ destes consideraram necessária a inclusão do fisioterapeuta na equipe da USF. Poucos entrevistados já foram, ou tiveram familiares, atendidos por fisioterapeuta, e 29\% afirmaram precisar atualmente destes serviços. Considerando-se o reduzido número de fisioterapeutas na Rede Municipal de Saúde e os benefícios que as pessoas poderiam auferir a partir de uma concepção menos restrita da 
profissão, propõe-se, dentro da lógica de valorização da participação popular na Atenção Básica, uma maior divulgação do campo potencial de atuação da Fisioterapia na Atenção Primária junto a esse segmento, atuando por meio de ações articuladas com as equipes de forma a qualificar cada vez mais a assistência no SUS.

\section{POLÍTICAS DE SAÚDE MENTAL NO MUNICÍPIO DE RIBEIRÃO PRETO - SP}

\section{Eduardo Miguel Febronio}

Orientador: Prof. Dr. Amaury Lelis Dal Fabbro

Dissertação de Mestrado apresentada em 23/03/2009

O estudo teve como objetivo descrever as políticas públicas de saúde na área de saúde mental no município de Ribeirão Preto - SP. Para isso procederam-se duas diferentes fases de coleta de dados. A primeira foi constituída de trabalho de campo realizado junto à Secretaria Municipal de Saúde para obtenção de dados sobre instrumentos normativos, financiamento, logística operacional e questões administrativas. Num segundo momento foram realizadas entrevistas com os diferentes atores do sistema de saúde mental, incluindo profissionais que atuam na atenção básica e saúde da família, de ambulatórios especializados, CAPS, hospital de urgência e hospital psiquiátrico, contemplando os vários níveis de complexidade da atenção ao paciente com problemas mentais. A análise do conteúdo das entrevistas foi embasada no método descrito por Bardin (1995).

Como resultados obtiveram-se através do diálogo estabelecido entre as diferentes visões dos atores envolvidos, além de uma completa descrição do sistema de saúde, diferentes opiniões sobre problemas, qualidades e possibilidades de caminhos para o sistema municipal de saúde mental de Ribeirão Preto. 